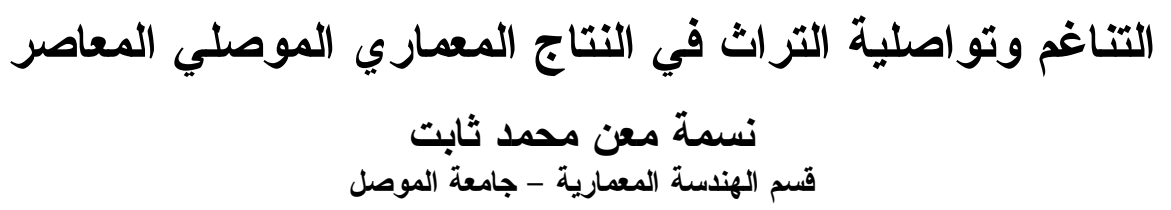

الخلاصة

تحددت مشكلة البحث بأهمية إثر اء المعرفة فيما بخص طبيعة العلاقة بين التراث و التتاغم وارتباطاتهما النظريــة

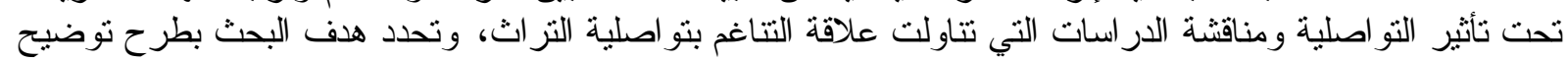

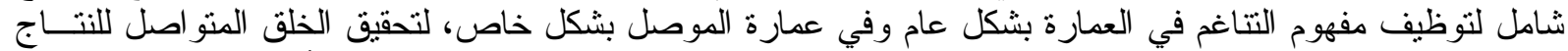

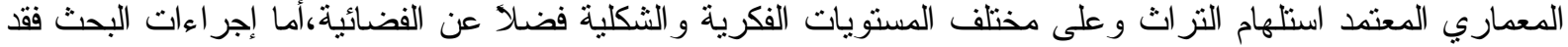

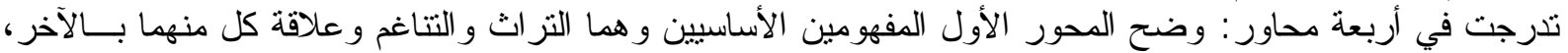

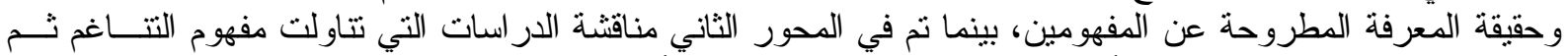

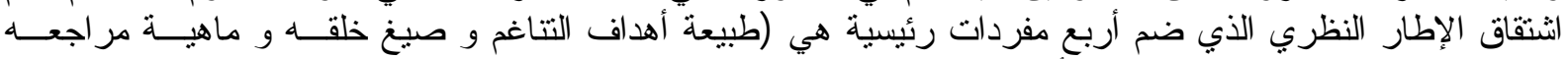

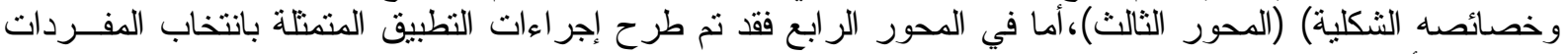

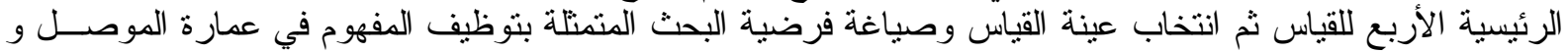

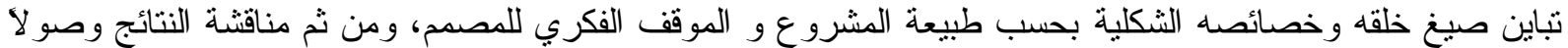

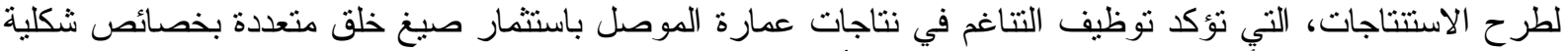

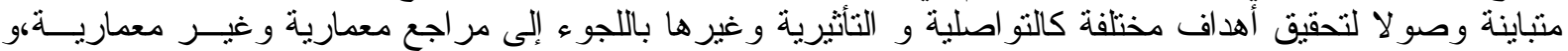

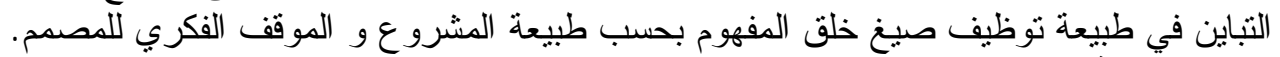
الكلمات ألدالة: التتاغم، نو اصلية التزر اثل، عمارة الموصل المعاصرة

\title{
The Rhythm and Heritage Continuity in Contemporary Mosul Architectural Product
}

\author{
Nasma M. Thabit \\ Department of Architecture\ University of Mosul
}

\begin{abstract}
The present study defines the research problem as a reformulation of a scientific aspect to study of the relations between heritage and rhythm under influence of continuity, and discusses the studies about the relations of rhythm with heritage continuity, this research clarifies how strategically usage for concept rhythm in architecture in achieving the communicated for architectural product depending heritage usage on different levels mentally,formally and specially, research contains four axes: discussing the relation between rhythm and heritage continuity, firstly, and discussing studies about rhythm,secondly, then differentiation the theoretical framework, thirdly, at last concluding the applying operations are submitted which represented by electing four main items of detailed theoretical field as the following:(Nature of rhythm aims, Rhythm greation forms, What the resources of rhythm is, Rhythm formal properties) which limit the concept in architecture, firstly,and the application of the items by electing two important projects in Mosul architecture(as models) and crystallized the hypothesis,secondly, at last discussing the results to submit the conclusions in the end.
\end{abstract}

Keywords: Rhythm, Heritage Continuity, Contemporary Mosul Architecture 


\section{$\begin{array}{llll}\text { Al-Rafidain Engineering } & \text { Vol.17 } & \text { No.5 } & \text { October } 2009\end{array}$}

1

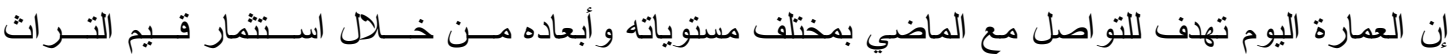

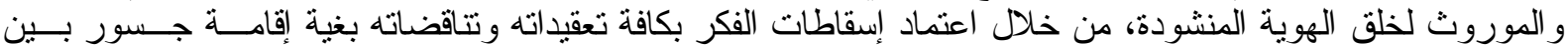

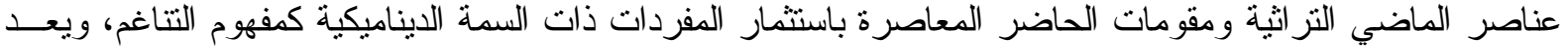

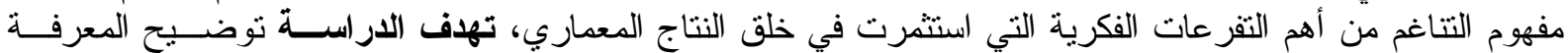

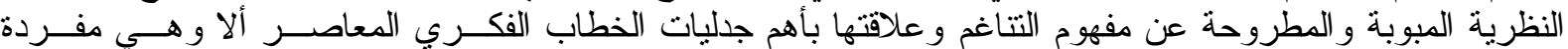

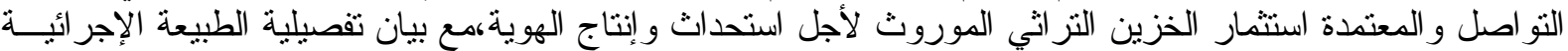

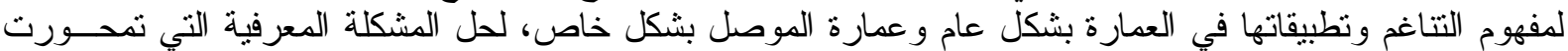

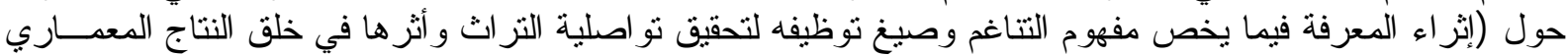

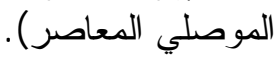

\section{2 - إجراعات البحث:}

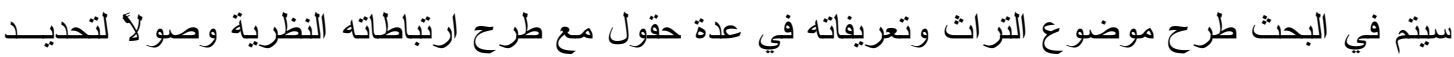

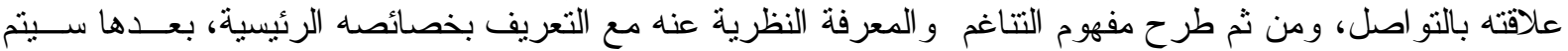

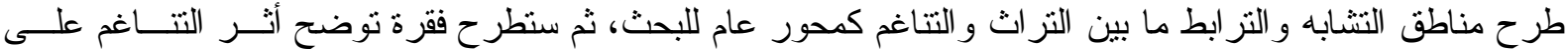

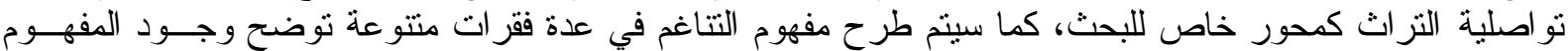

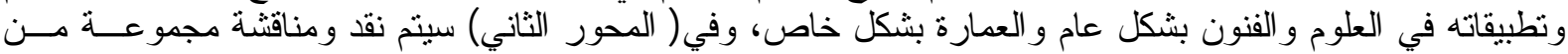

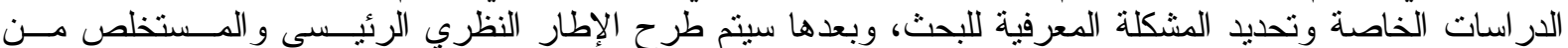

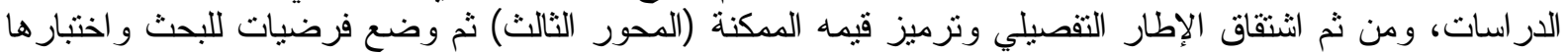

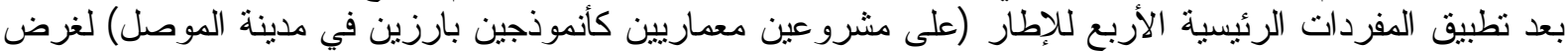

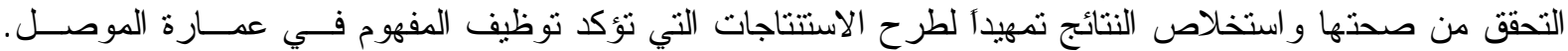

1-2 2 المحور الأول (المفاهيم النظرية الرئيسية):

1- 1-2 1- 1- 1فهوم التراث (التعريفات النظرية):

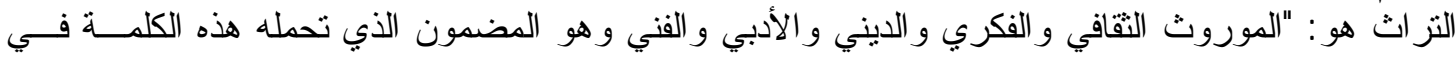

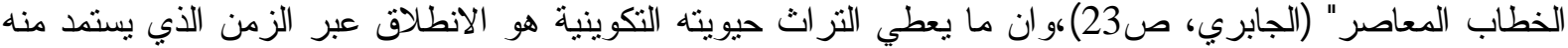

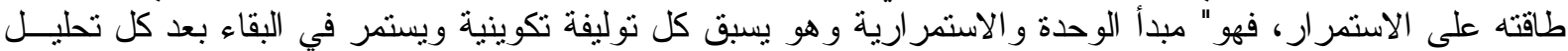

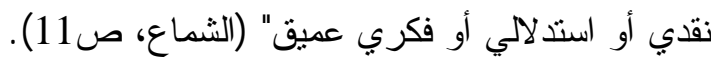

2-1-2 2 الارتباطات النظرية لمفهوم التراث:

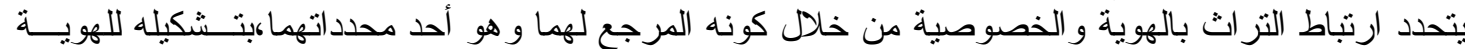

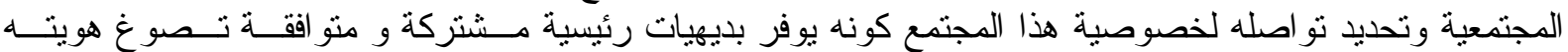

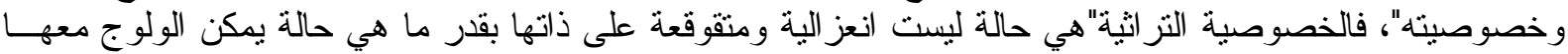

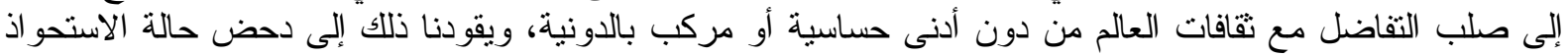

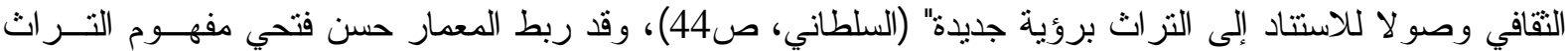

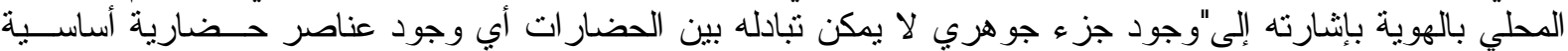

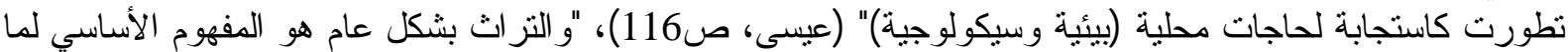

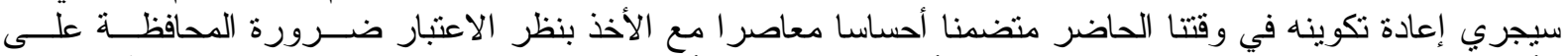

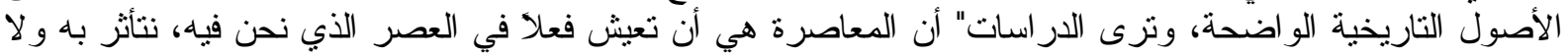

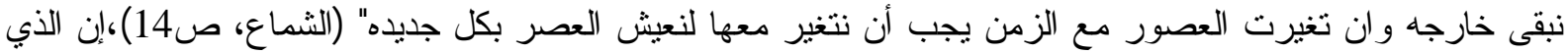

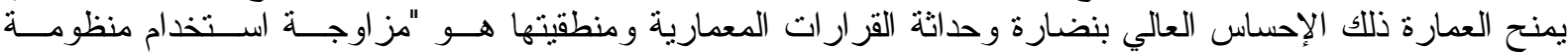

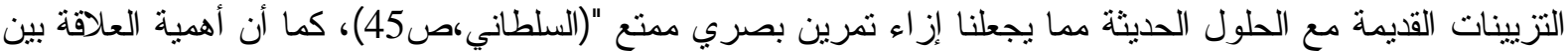

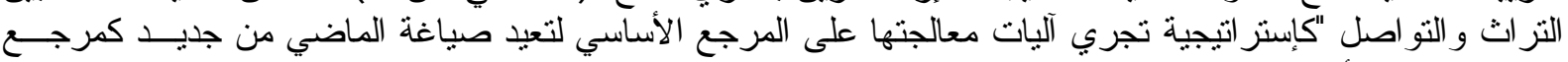

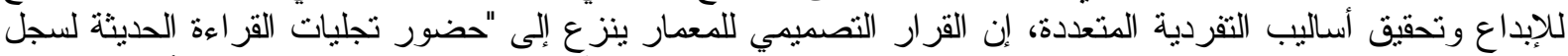

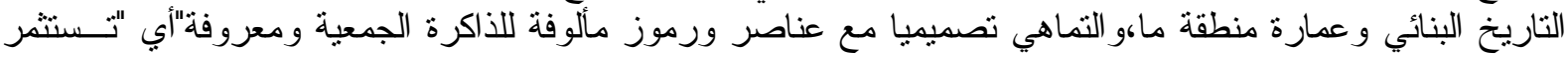




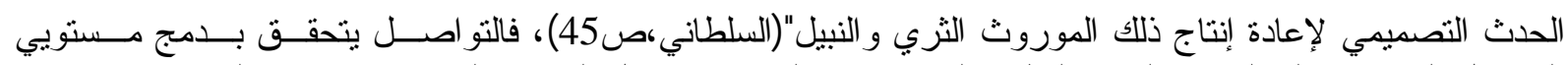

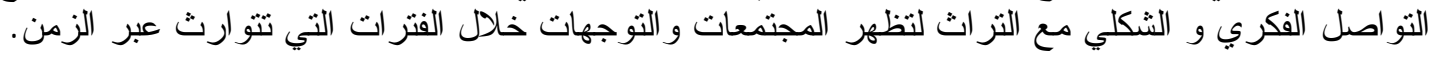

2-1 2 - 2

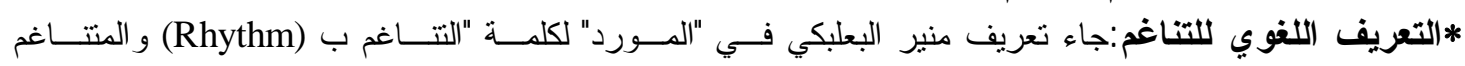

(Rhythmic)

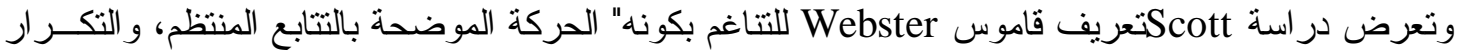

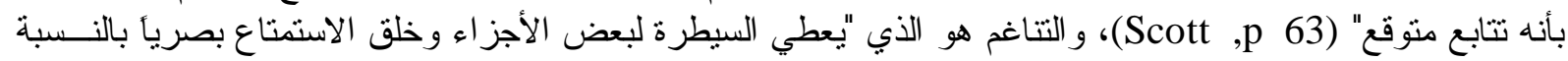

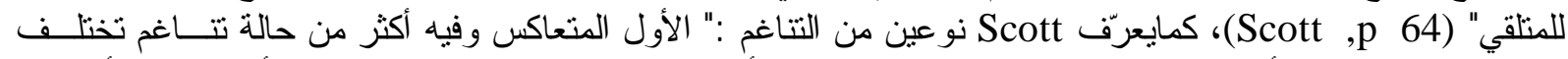

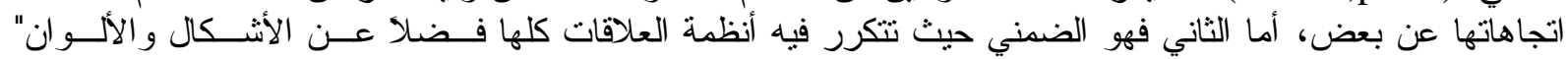
.(Scott, p 63)

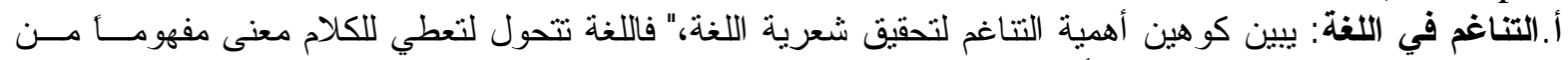

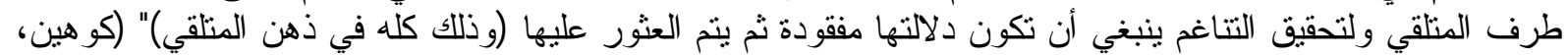

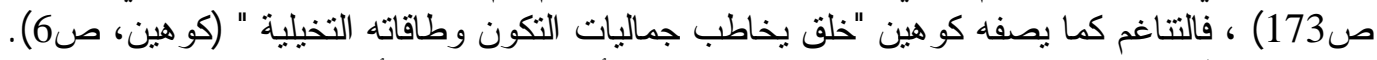

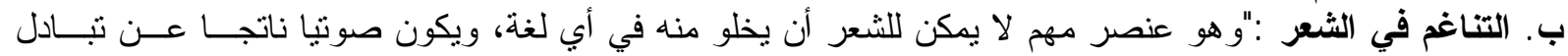

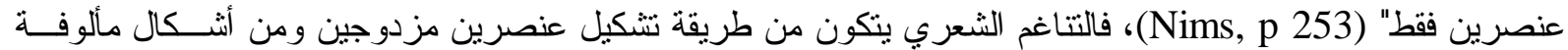
متعارف عليها في اللغة المحلية وهي الأوزان الشعرية فئرية

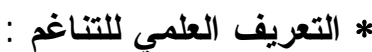

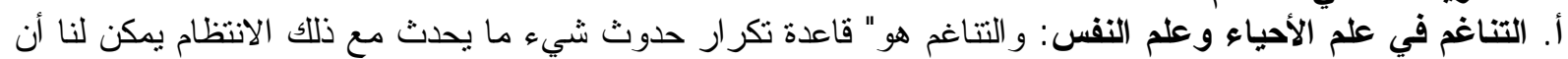

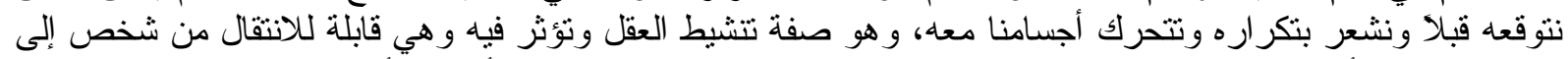

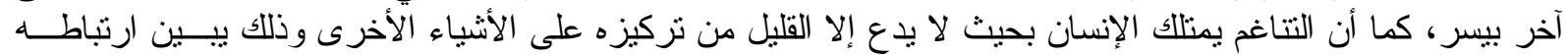

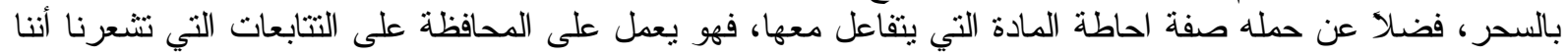

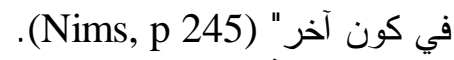

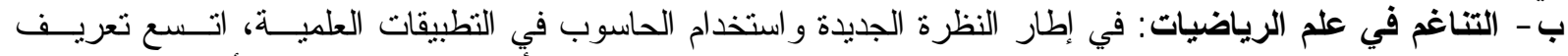

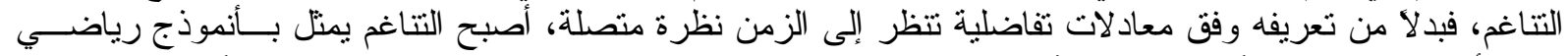

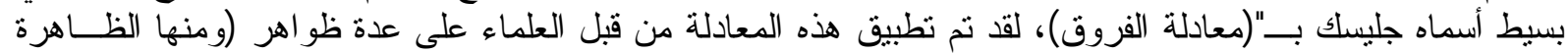

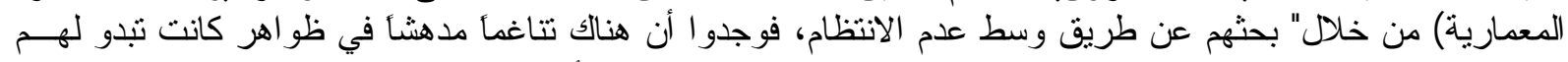

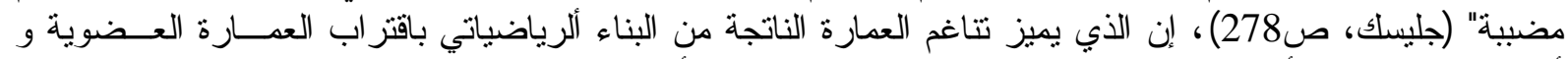

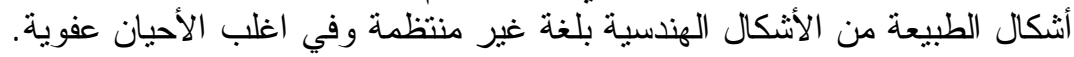

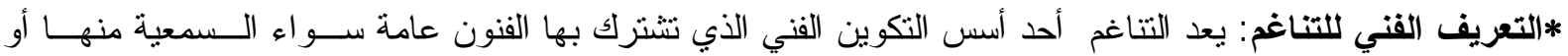

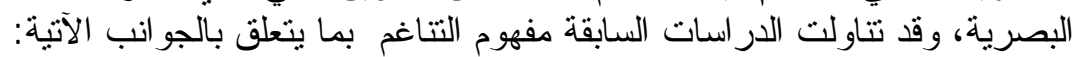

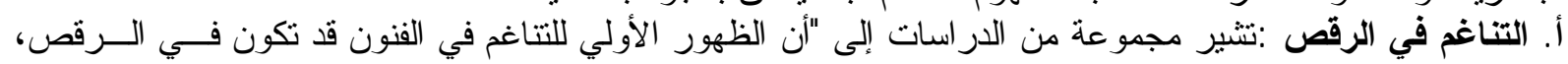

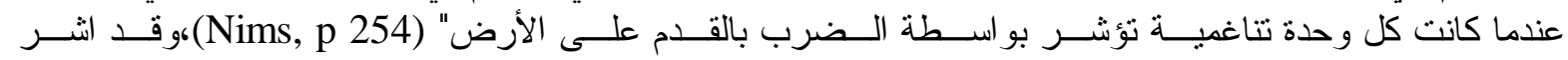

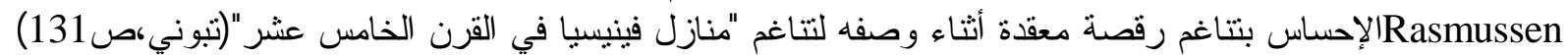

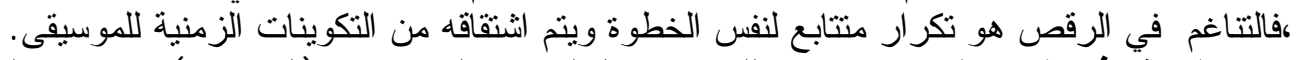

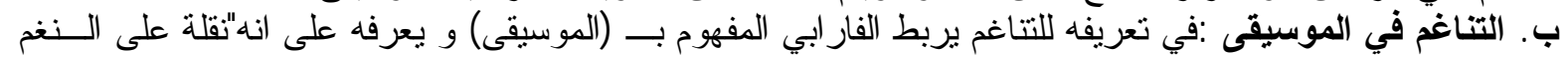

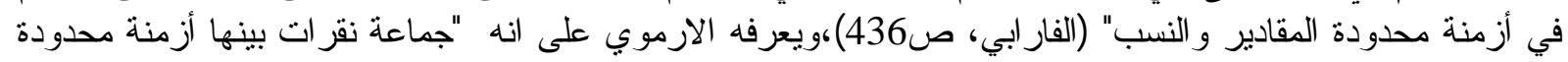

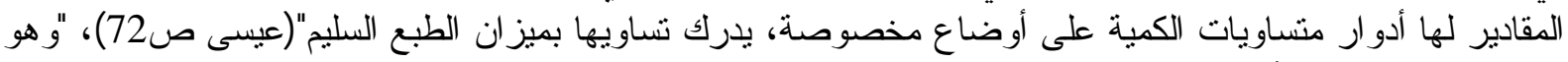

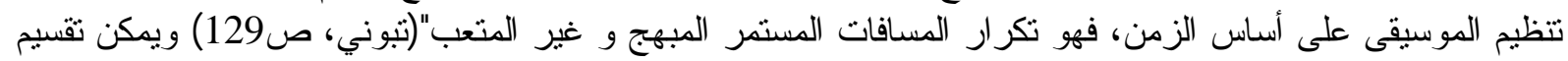

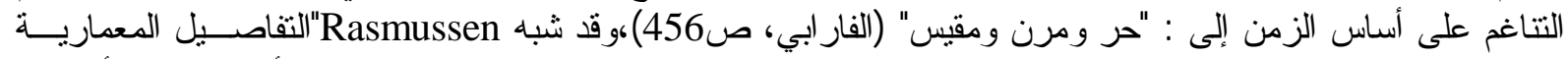

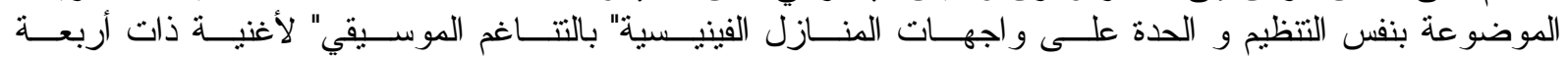

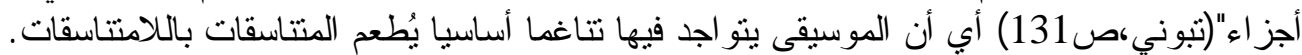

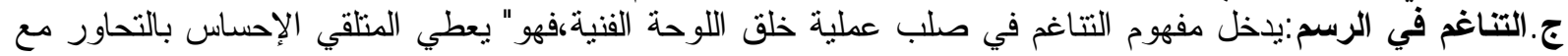

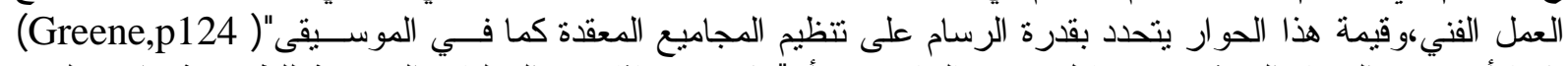

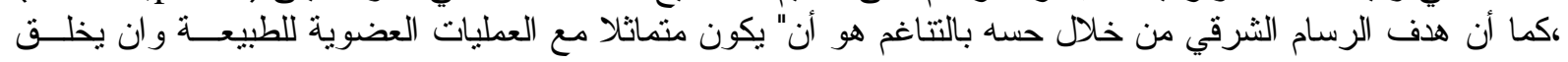




\section{$\begin{array}{llll}\text { Al-Rafidain Engineering } & \text { Vol.17 } & \text { No.5 } & \text { October } 2009\end{array}$}

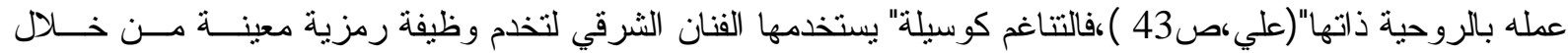
تمثنيلها التتاغم الأبدي في الكون"(علي،433 ).أي أن التتاغم من الصفات الجوهرية التي تشكل جمال العمل الفني مـن

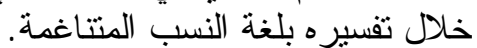

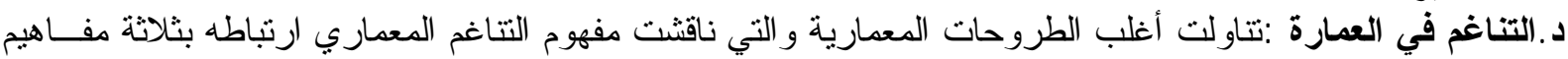

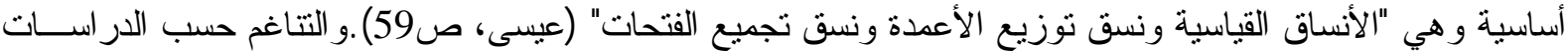

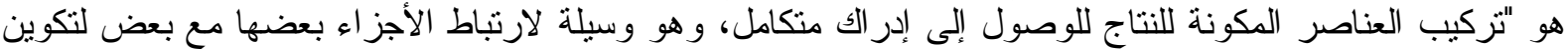

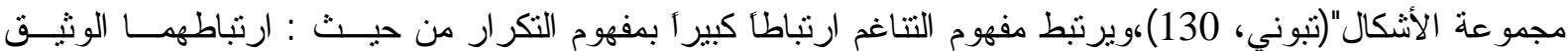

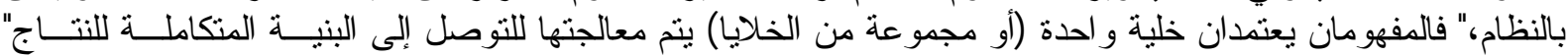

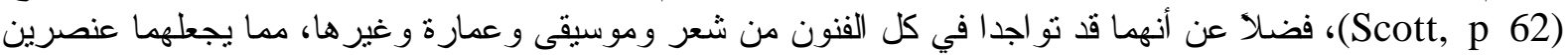

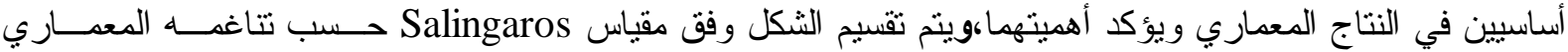

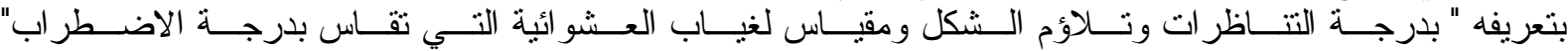

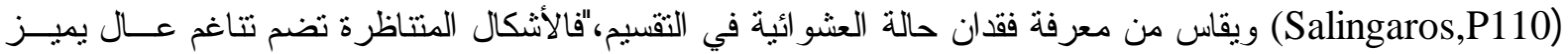

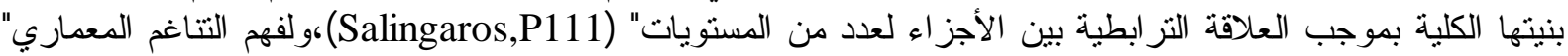

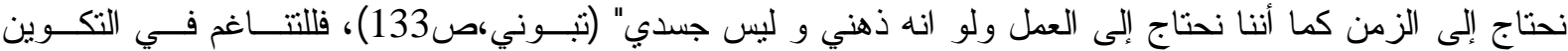

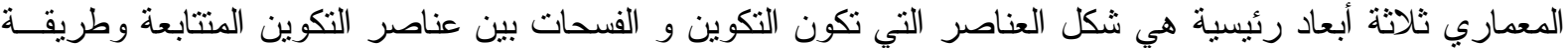

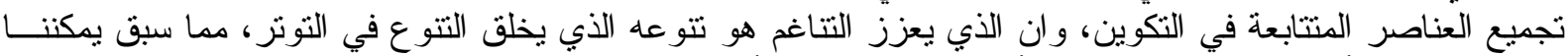

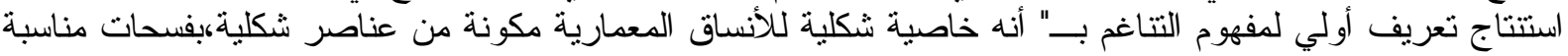

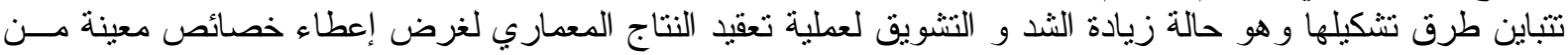

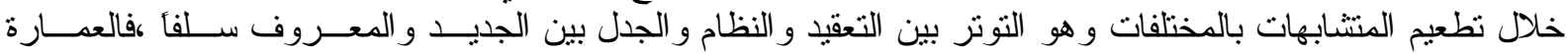

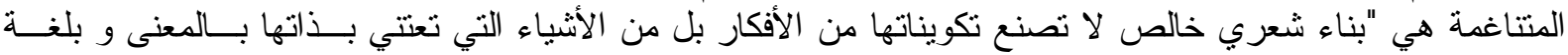

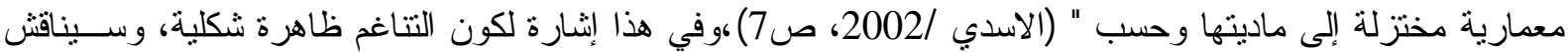

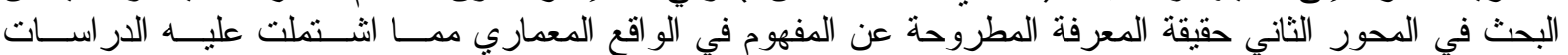

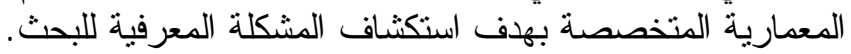

2 - 2 -4 علاقة التراث بالتناغم :إن عملية تحليل التتاغم ودر اسة الأوزان المعمارية لطرق عمل التكوينات الثكلية مـــع

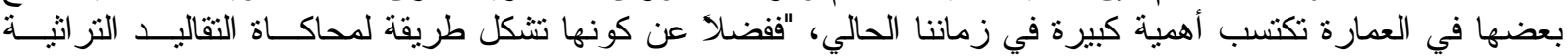

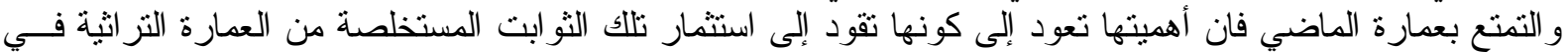

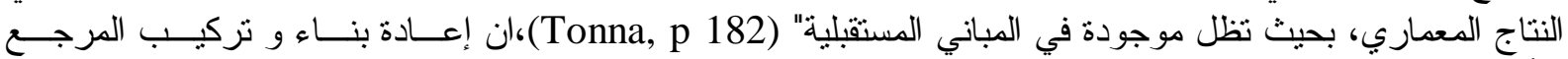

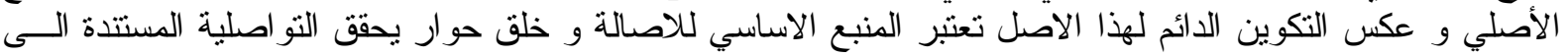

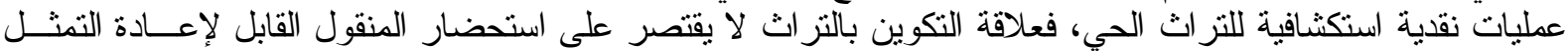

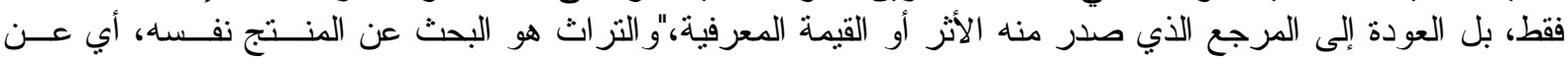

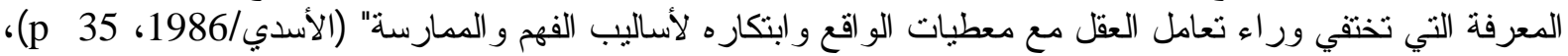

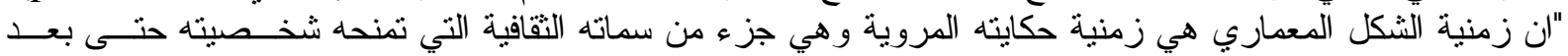

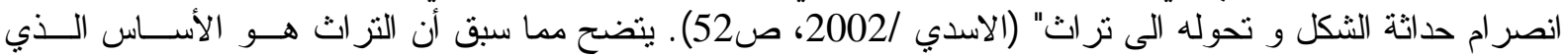

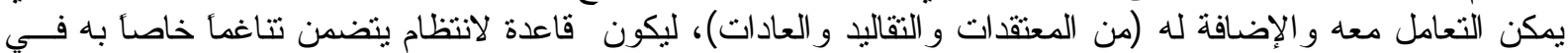
البيئة المجتمعية، من خلال القدرة على التر ابط بين القديم و الحديث.

: 2 - 2 تواصلية التراث باعتماد التتاغم

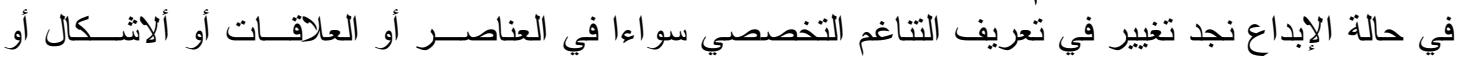

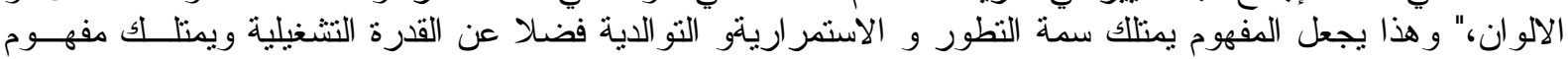

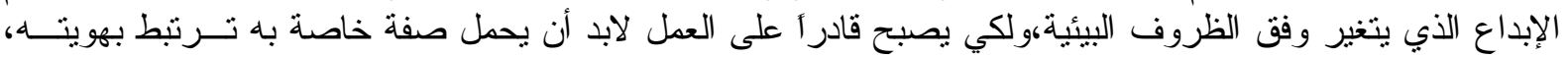

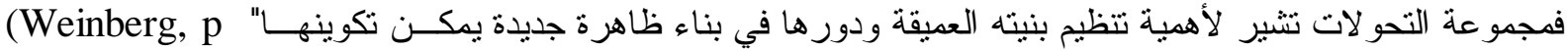

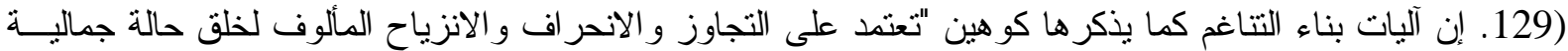

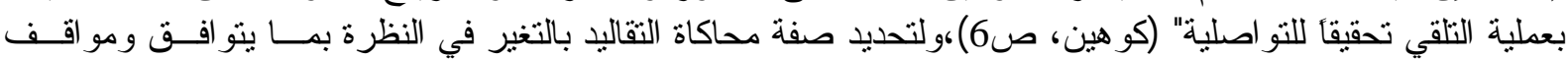

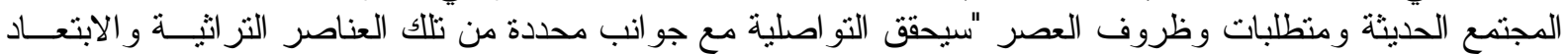

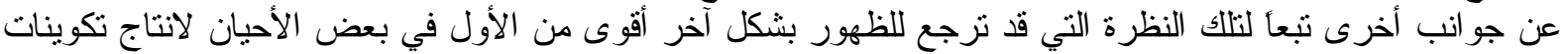

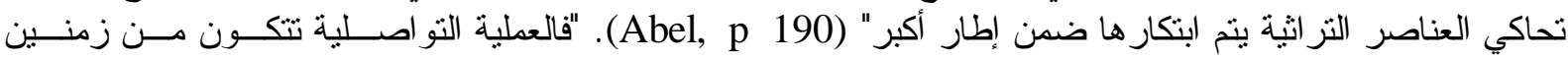

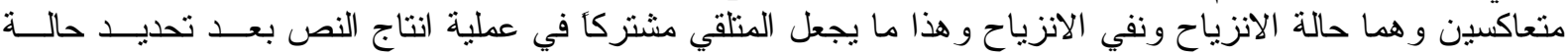


انزياحه يعمل ذهنه لأجل تحقيق حالة نفي الانزياح وبذلك يشترك في تكوين الفكرة" (كو هين، ص173)، وفي هذا اشارة

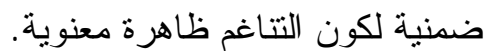

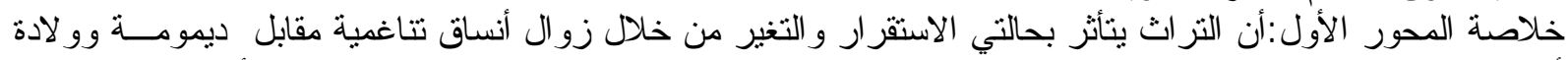

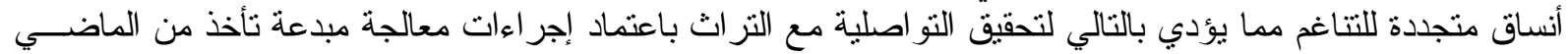

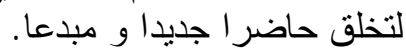

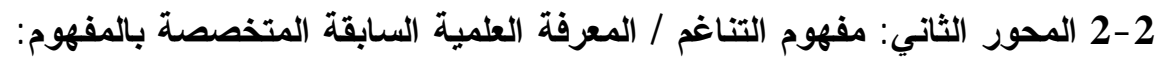

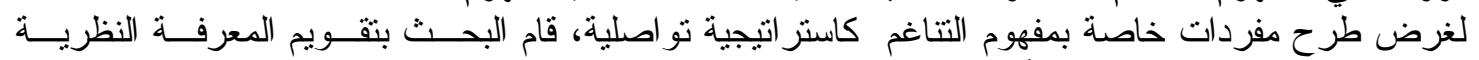

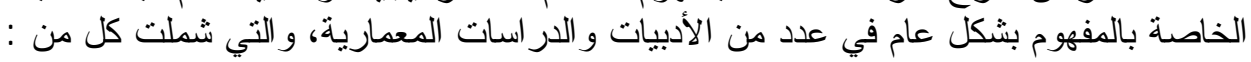

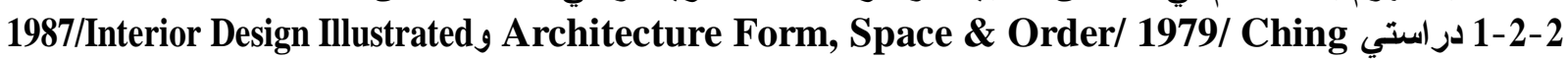

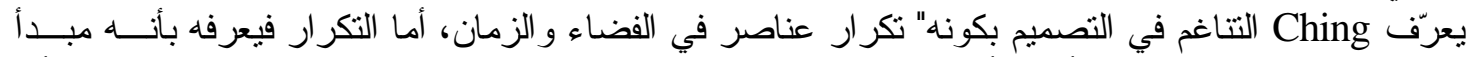

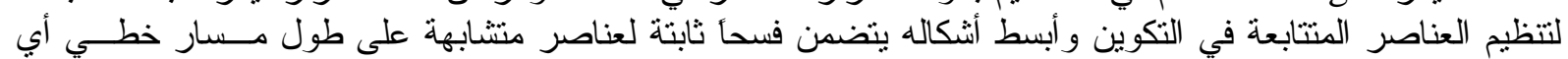

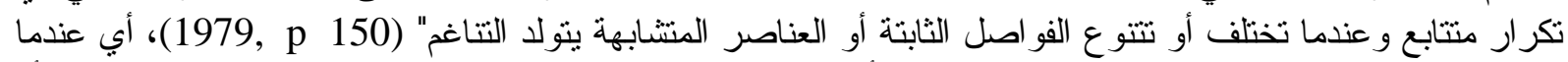

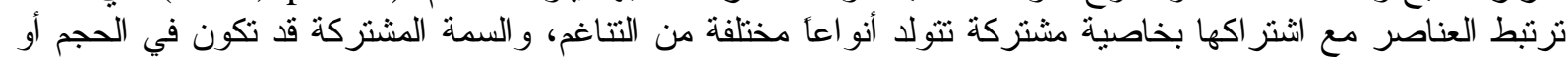

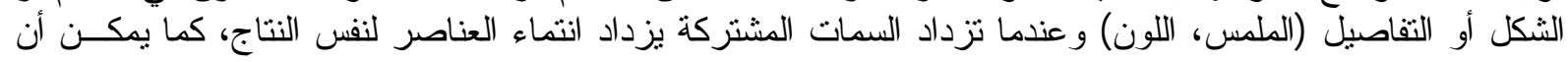

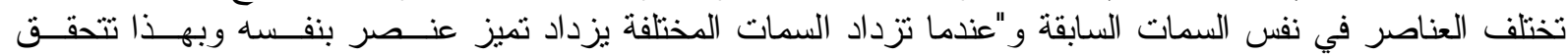

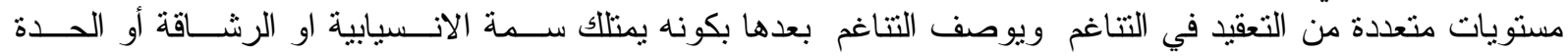

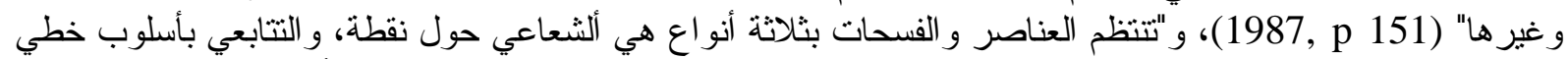

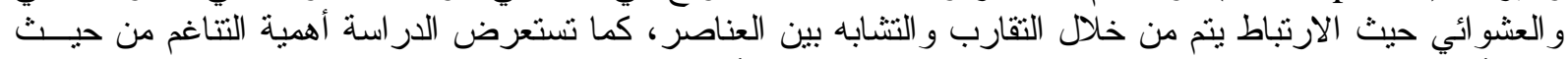

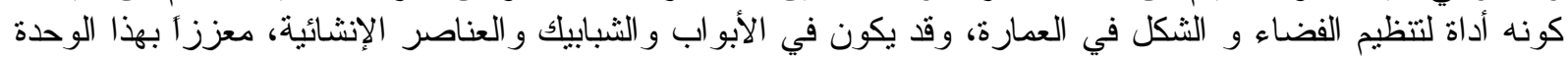

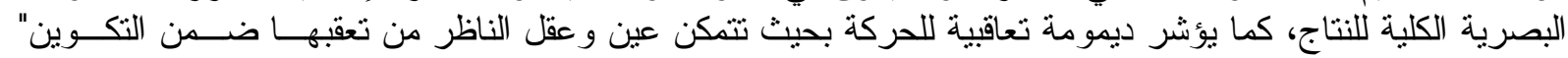

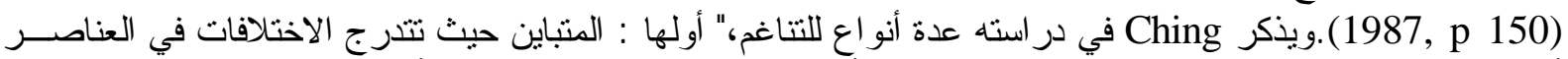

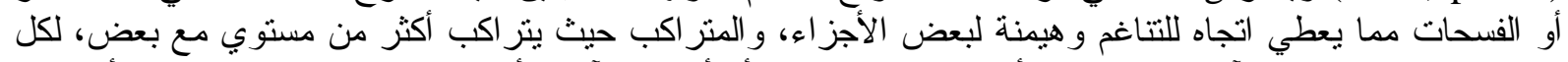

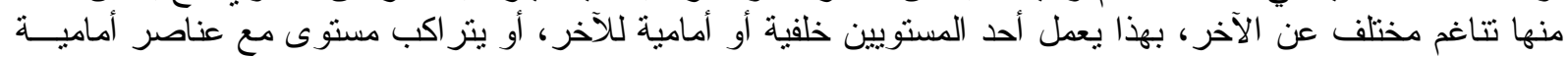

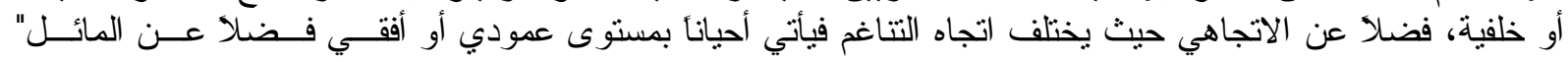
.(1987, p 152)

1988/ Architecture Today/Jencks 2-2-2

ناقشت الدر اسة توظيف معماريي توجه احيائية العشرينات التتاغم وبخاصة المتر اكب في الواجهات التهات ومن خلال

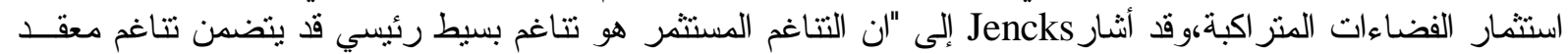

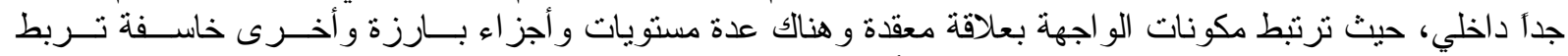

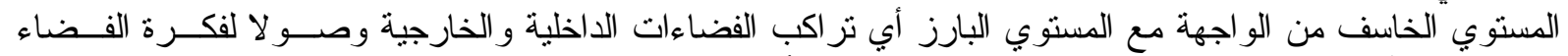

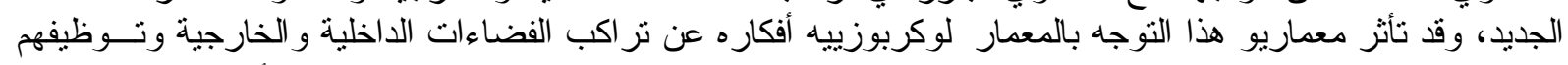

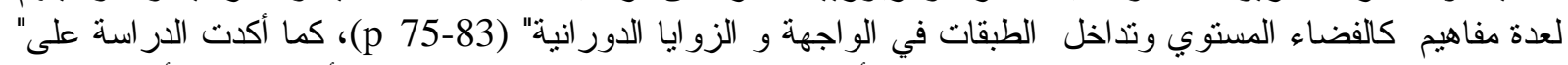

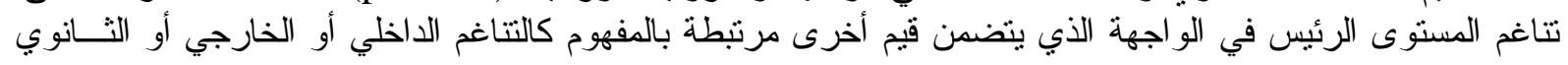

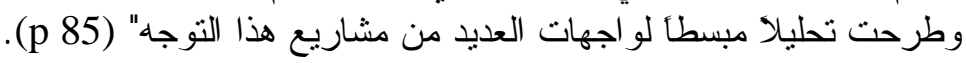

1997 / The Architecture of Jumping Universe / Jencks درة 2-2 2

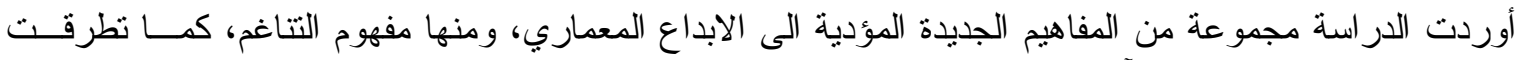

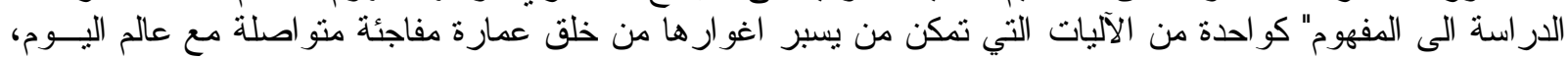

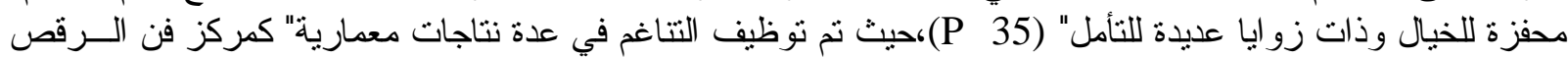

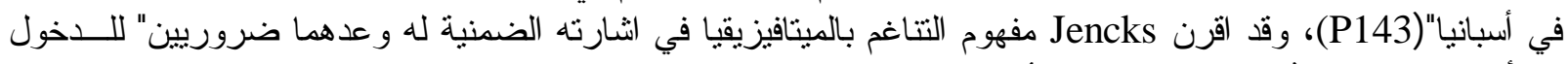

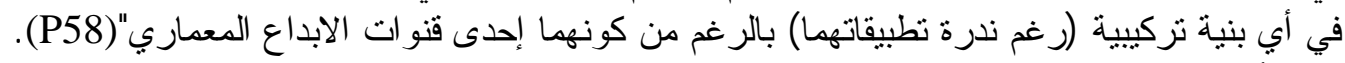

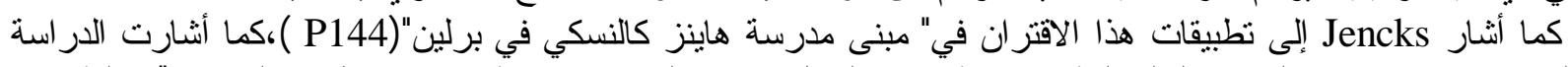

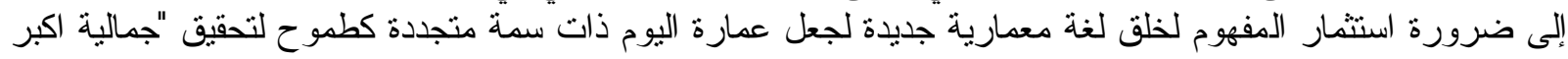

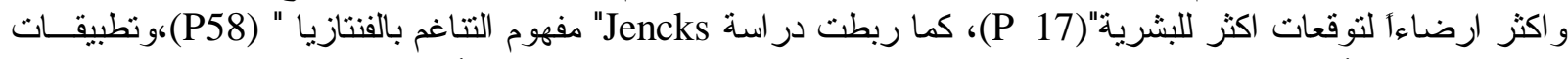

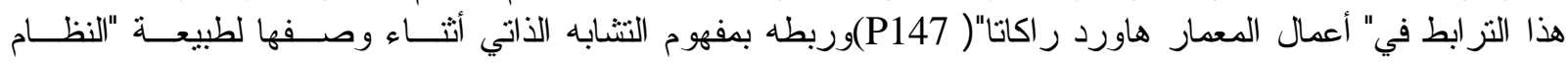

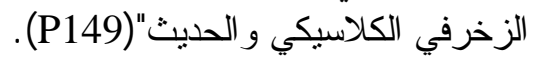


:1985/Experiencing Architecture / Rasmuseen 4-2-2

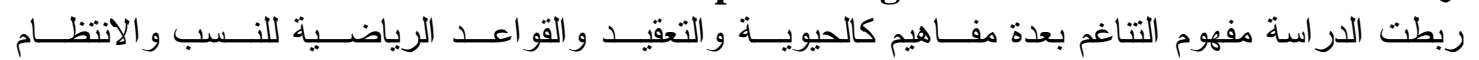

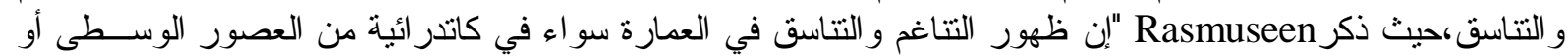

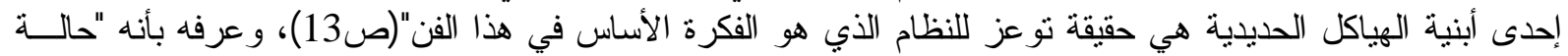

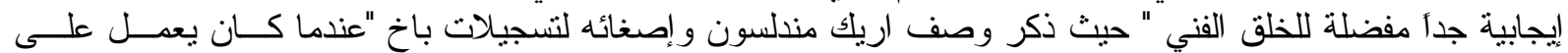

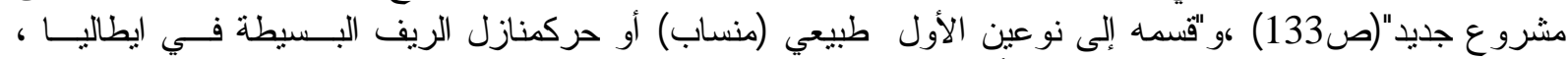

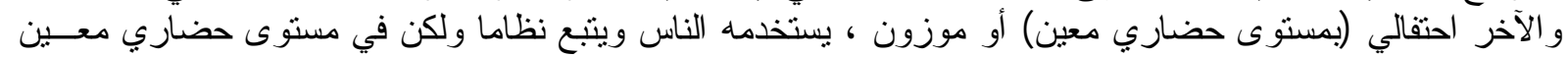

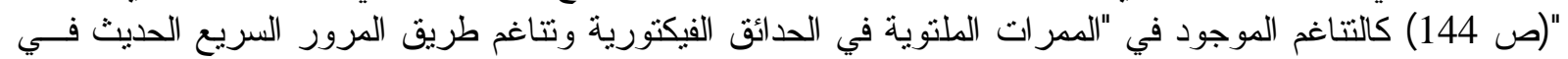

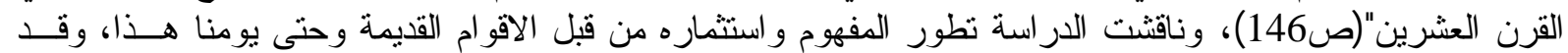

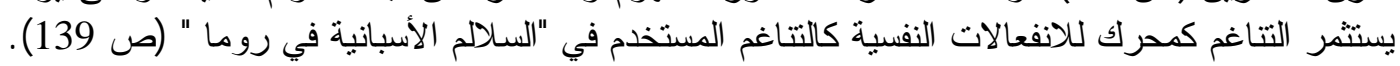

:1980 / Mind And Image / Greene 2-2 2

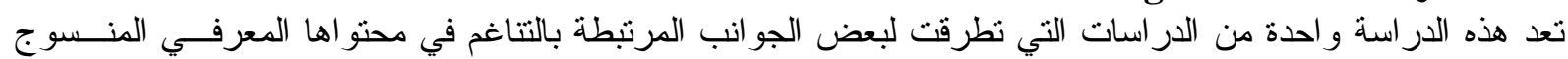

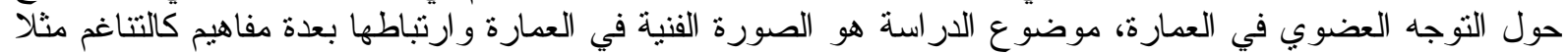

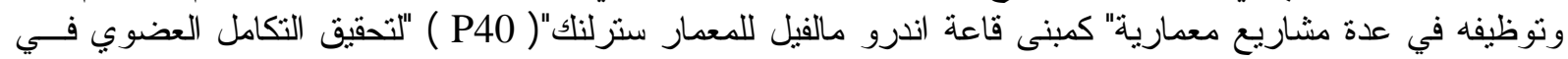

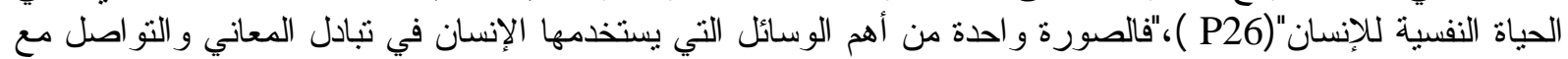

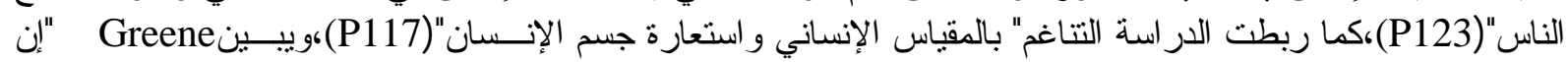

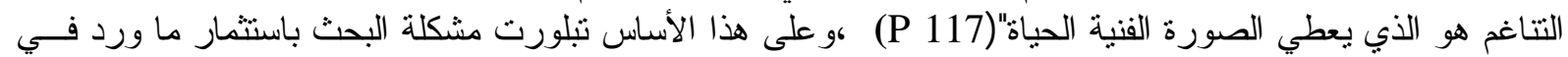

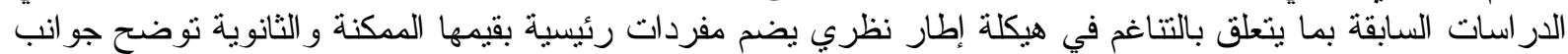
المفهوم و أهمية نوظيفه .

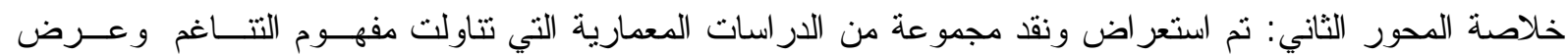

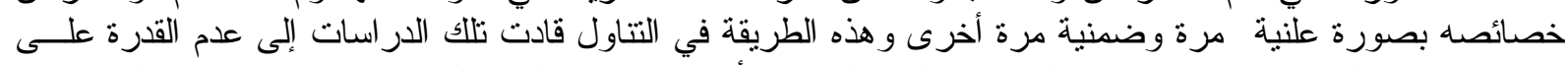

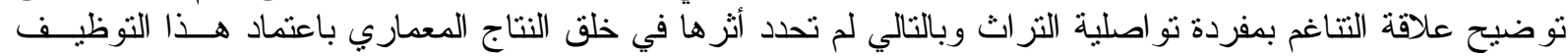

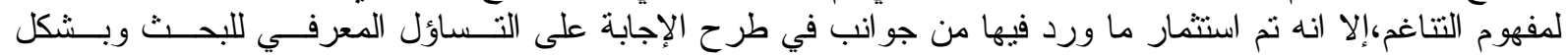
تقصيلي بوضع قياس دقيق في المحور الثالث.

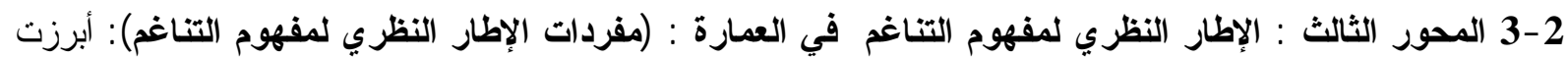

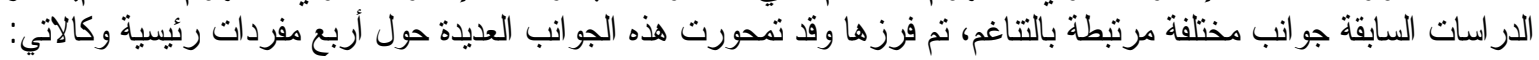

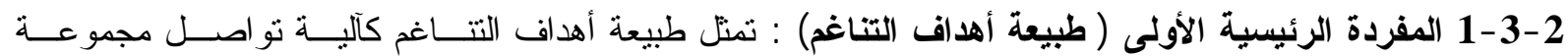

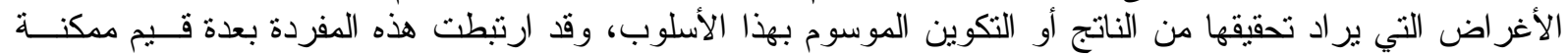

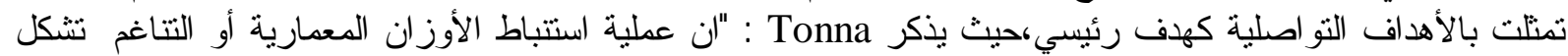

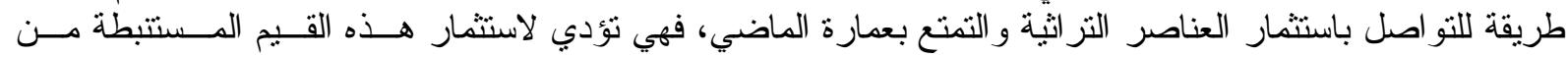

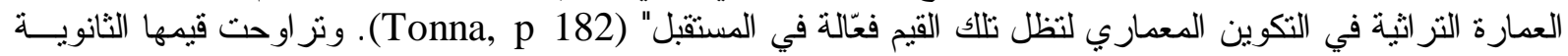

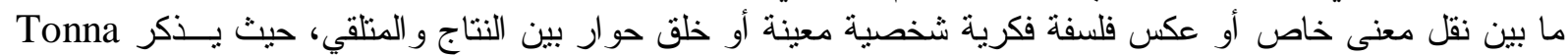

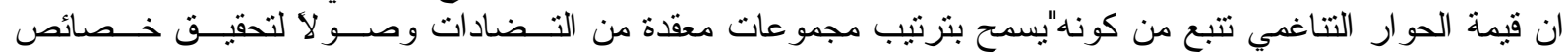

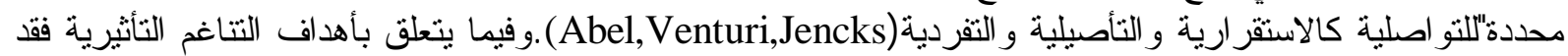

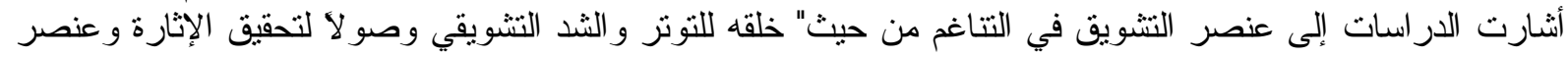

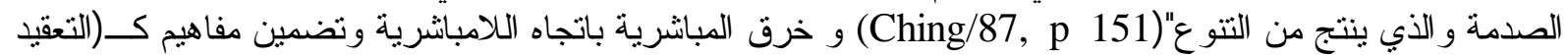

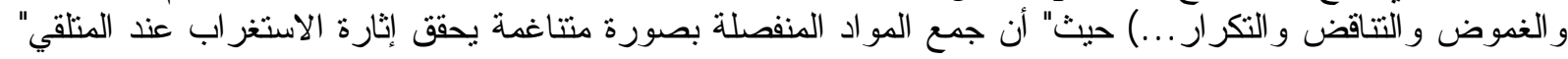
(Jencks, 1997, P 40)

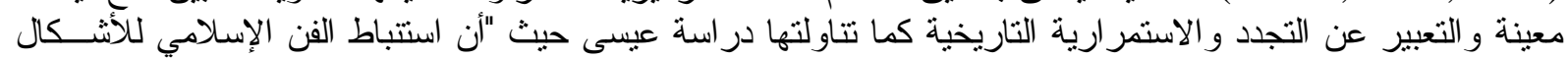

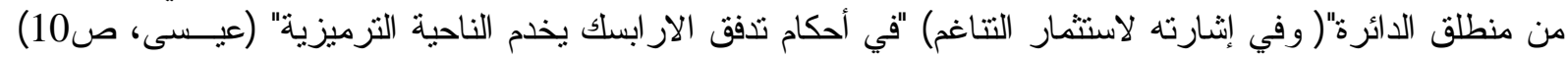

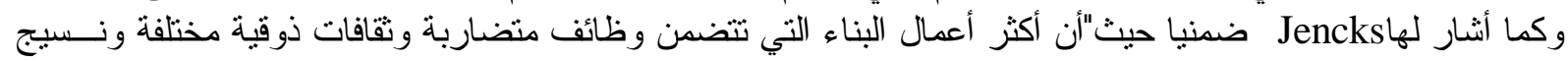

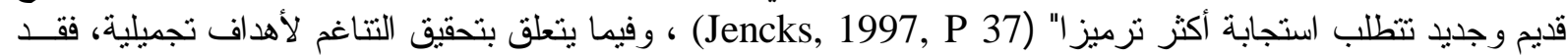

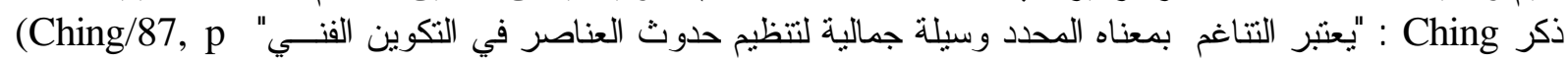




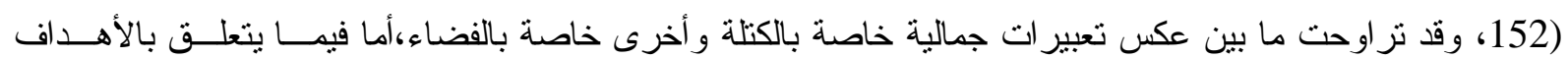

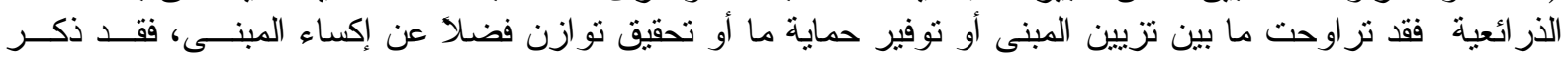

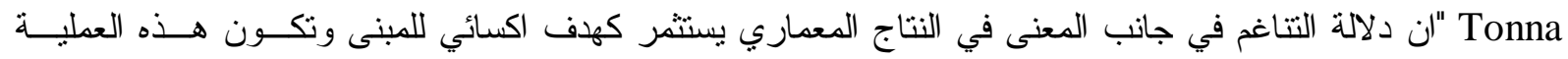

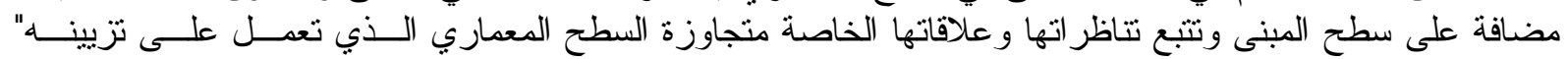

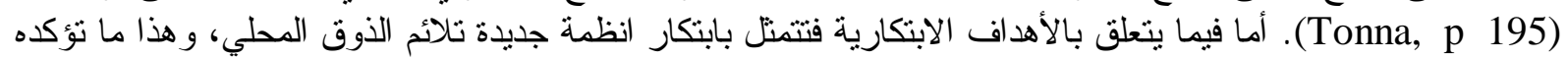

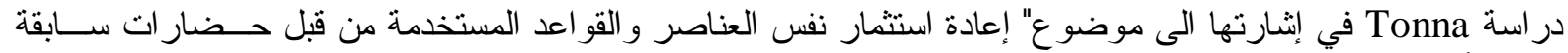

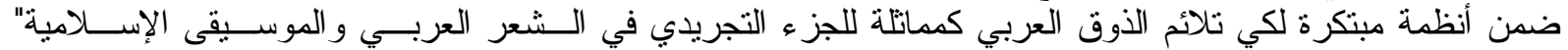

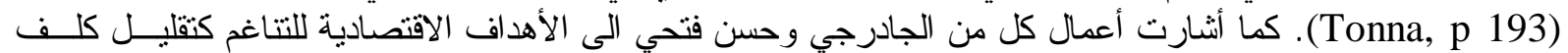

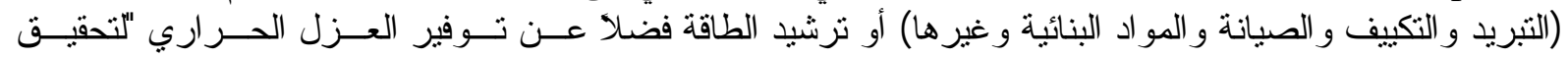

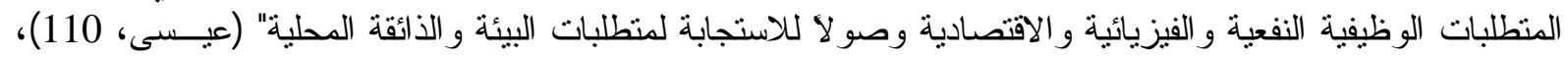

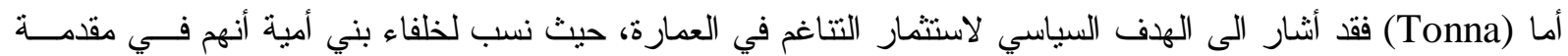

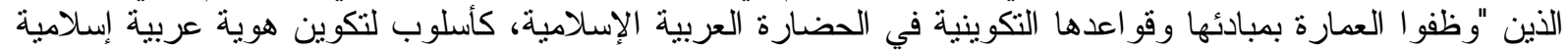

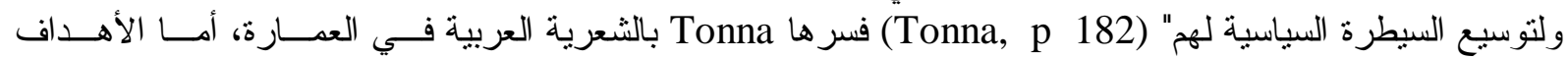

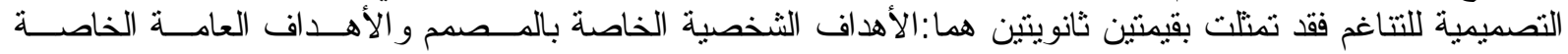

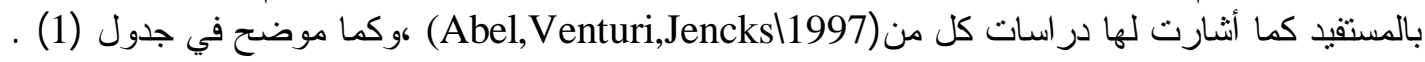

جدول (1) القيم الثانوية للقيم المكنة للمفردة الرئيسية الأولى : طبيعة أهداف التناغم

\begin{tabular}{|c|c|c|c|}
\hline 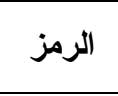 & 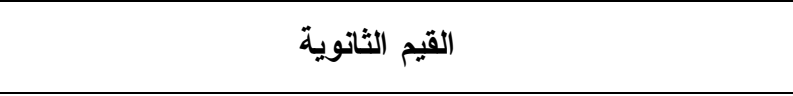 & القيم الممكنة القيم & المفردة الرئيسيةة \\
\hline $1-1-1$ & نقل معنى خاص & \multirow{4}{*}{ 1 1 - 1 نو اصلية } & \multirow{21}{*}{1 - طبيعة أهداف } \\
\hline 2-1-1 & عكس فلسفة فكرية شخصية معينة & & \\
\hline 3-1-1 & خلق حو ار بين النتاج و المتلقي & & \\
\hline 4-1-1 & تحقيق خصائص التو اصلية كالاستقر ارية و التأصيلية و التفردية & & \\
\hline $1-2-1$ & الإثارة و عنصر الصدمة & \multirow{3}{*}{ 2 1} & \\
\hline 2-2-1 & التوتز و الثند النتويقي & & \\
\hline $3-2-1$ & الللامباثرية وتضمين مفاهيم كــ(التعقيد و الغموض و النتاقض ..) & & \\
\hline $1-3-1$ & منح قيمة معينة & \multirow{2}{*}{1 -3 ترميزية } & \\
\hline $2-3-1$ & تعبير عن التجدد و الاستمر ارية الحضارية & & \\
\hline 1-4- 1 & عكس تعبير ات جمالية خاصة بالكتلة & \multirow{2}{*}{ 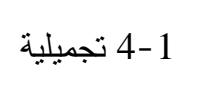 } & \\
\hline 2-4- 1 & عكس تعبير ات جمالية خاصة بالفضاء & & \\
\hline $1-5-1$ & تزيين & \multirow{4}{*}{ 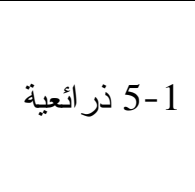 } & \\
\hline $2-5-1$ & توفير حماية ما & & \\
\hline 3-5-1 & تحقيق تو ازن & & \\
\hline 4-5-1 & اكساء & & \\
\hline $1-6-1$ & ابتكار أنساق جديدة تلائم الذائقة المحلية & 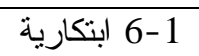 & \\
\hline 1-7-1 & تقليل كلف (تبريد وتدفئة، تكييف، صيانة، مو اد، الخ) & \multirow{2}{*}{ 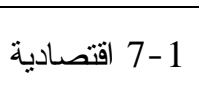 } & \\
\hline $2-7-1$ & ترشيد طاقة، عزل حر اري & & \\
\hline $1-8-1$ & إقامة هوية ما (لتوسيع الهيمنة السياسية) & (8-1 1 سياسية & \\
\hline 1-9-1 & أهداف شخصية خاصة بالدصمم & \multirow{2}{*}{1 -9 تصميمية } & \\
\hline 2-9-1 & أهد اف عامة خاصة بالمستقيد & & \\
\hline
\end{tabular}

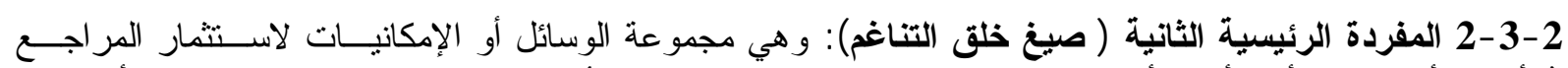

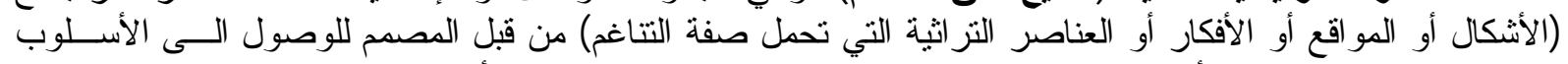

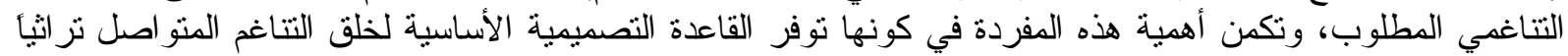

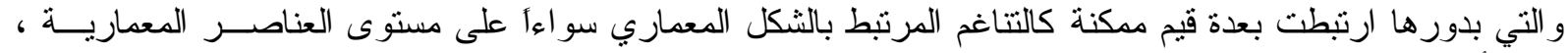

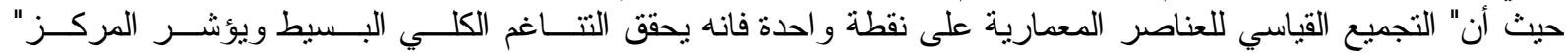




\section{$\begin{array}{llll}\text { Al-Rafidain Engineering } & \text { Vol.17 } & \text { No.5 } & \text { October } 2009\end{array}$}

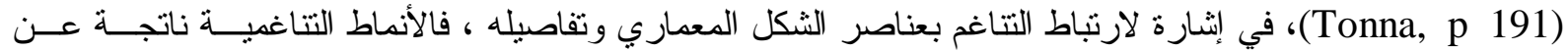

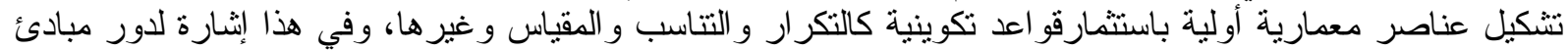

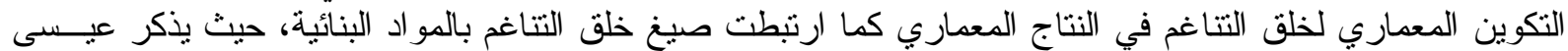

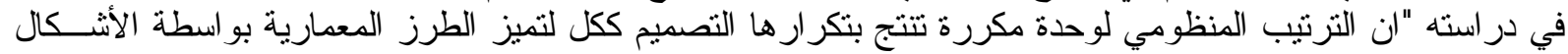

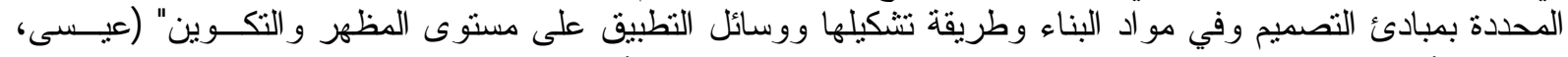

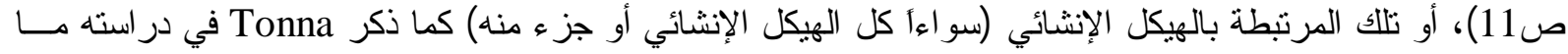

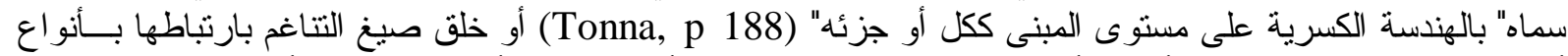

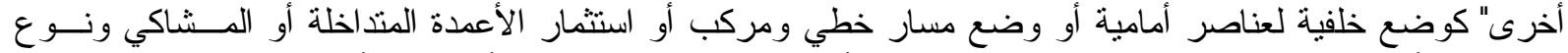

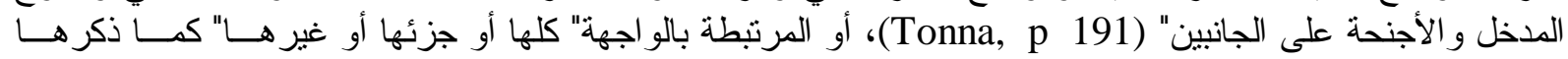

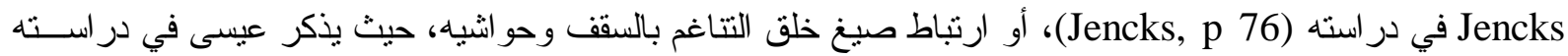

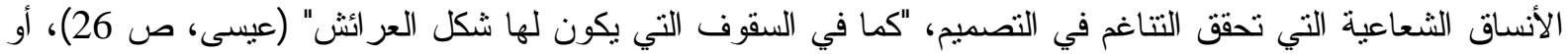

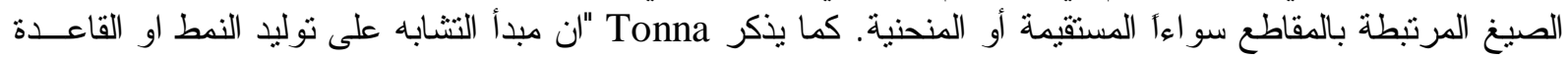

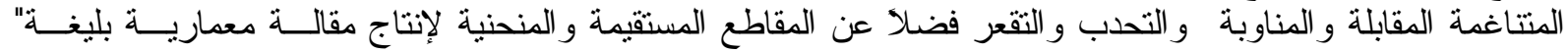

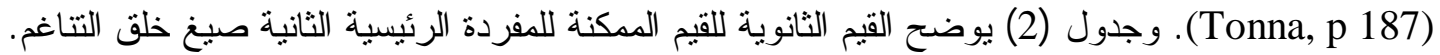

جدول (2) القيم الثانوية للقيم الممكنة للمفردة الرئيسية الثانية : صيغ خلق التناغم

\begin{tabular}{|c|c|c|c|}
\hline 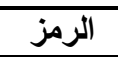 & القيم الثانوية & القيم الممكنة & المفردة الرئيسية الثانية \\
\hline $1-1-2$ & عناصر الثكل & \multirow{3}{*}{ 1-2 المرتبطة بالثكل } & \multirow{16}{*}{2 - صيغ خلق التتاغم } \\
\hline $2-1-2$ & تفاصيل الثكل & & \\
\hline 3-1-2 & مبادئ التكوين المعماري & & \\
\hline $1-2-2$ & خاصة بالمظهر & \multirow{2}{*}{ 2-2 المرتبطة بالمو اد البنائية } & \\
\hline $2-2-2$ & خاصة بالتكوين & & \\
\hline $1-3-2$ & كل الهيكل الحقيقي & \multirow{3}{*}{ 3-2 المرتبطة بالهيكل } & \\
\hline 2-3-2 & جزء من الهيكل الحقيقي & & \\
\hline 3-3-2 & أخرى & & \\
\hline $1-4-2$ & 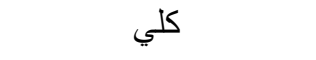 & \multirow{3}{*}{2 -4 المرتبطة بالو اجهة } & \\
\hline 2-4- 2 & جزئي & & \\
\hline 3-4- 2 & أخرى & & \\
\hline $1-5-2$ & التتاغم المتكرر & \multirow{3}{*}{ و المرتبطة بالسقف } & \\
\hline $2-5-2$ & حو اثشي السقف & & \\
\hline $3-5-2$ & أخرى & & \\
\hline $1-6-2$ & المقاطع المستقيمة & \multirow{2}{*}{2 -6 المرتبطة بالمقاطع } & \\
\hline $2-6-2$ & الدقاطع المنحنية & & \\
\hline
\end{tabular}

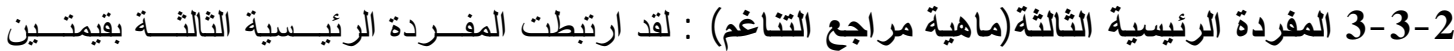

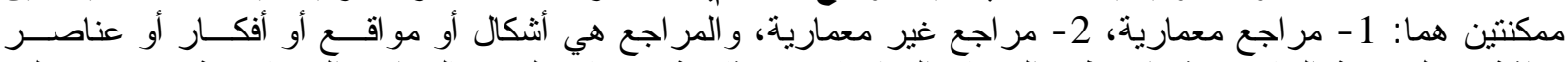

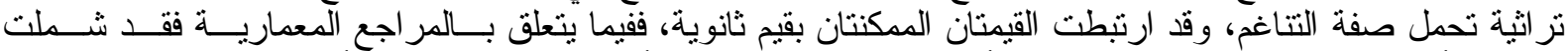

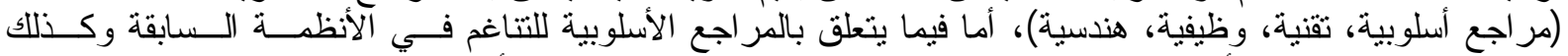

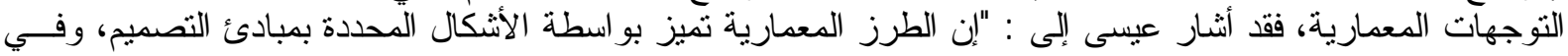

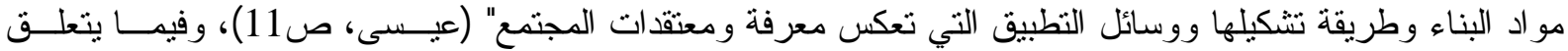

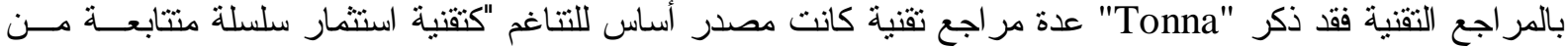

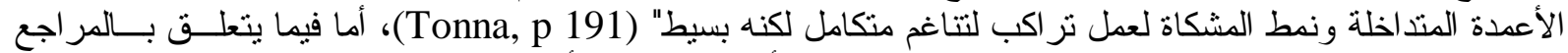

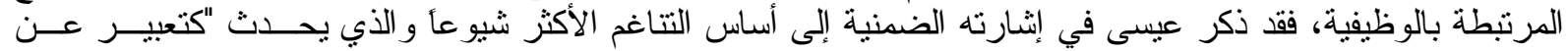

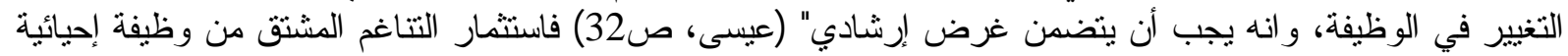

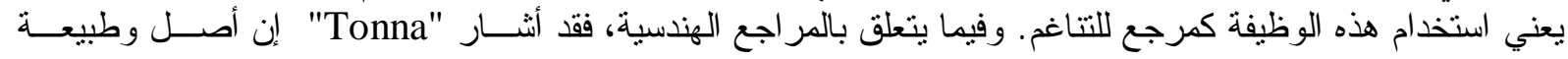




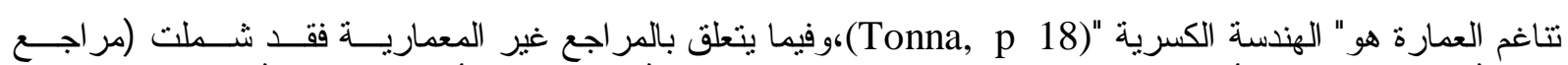

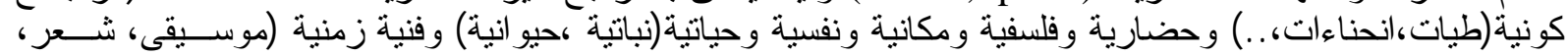

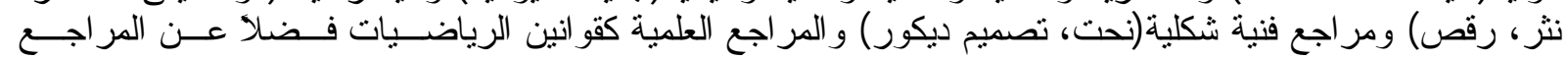

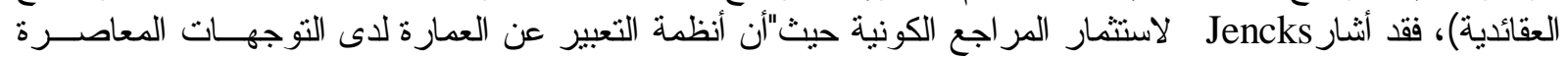

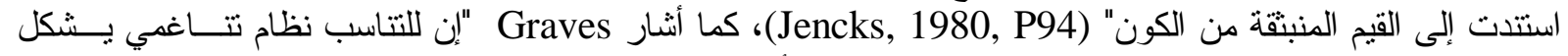

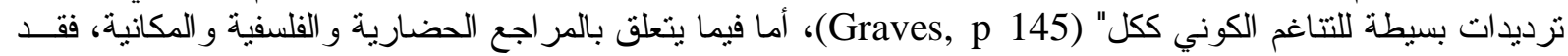

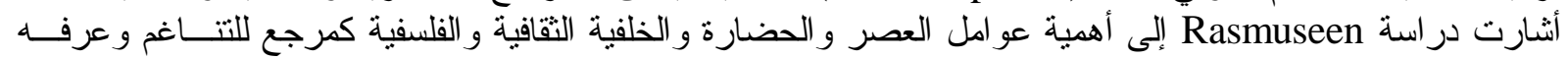

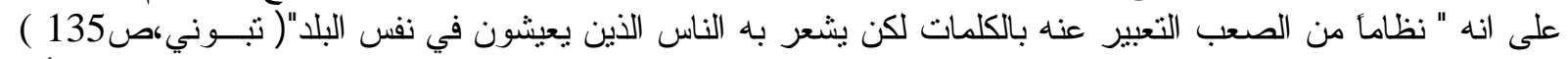

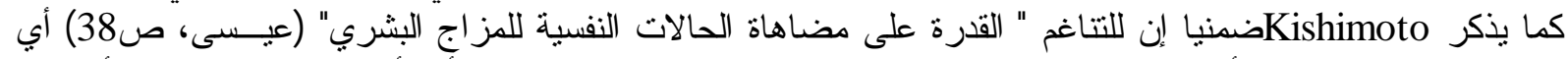

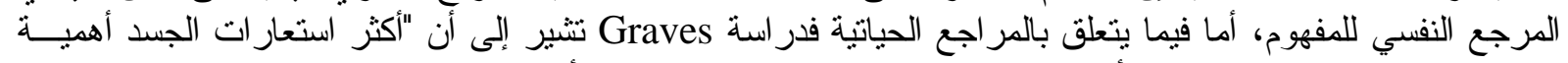

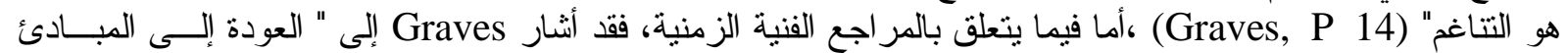

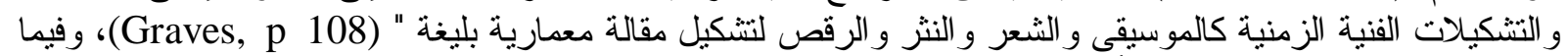

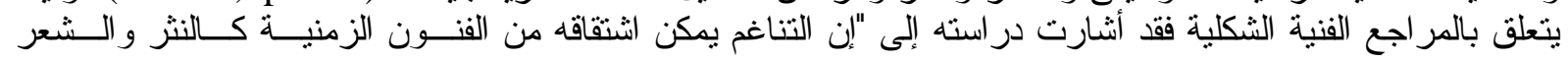

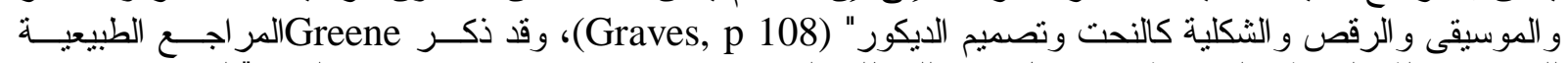

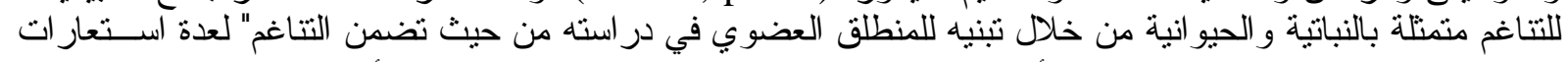

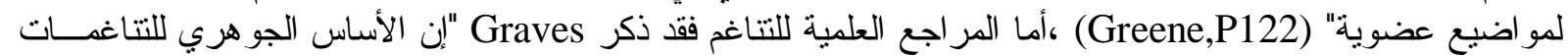

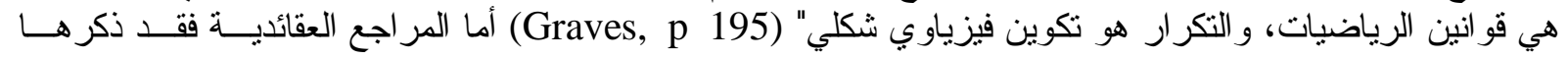

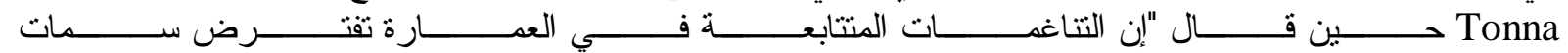

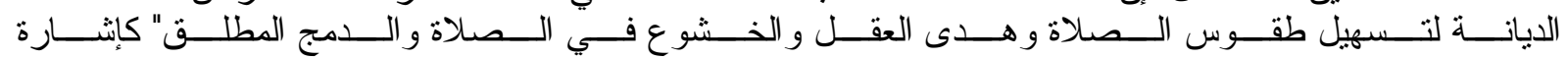

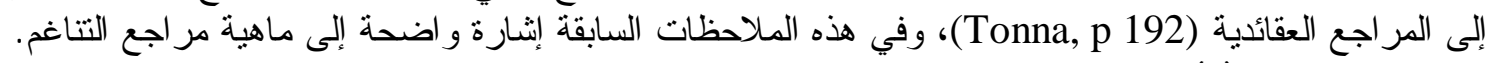
والجدول (3) يوضح المفردة الرئيسية الثالثة بقيمنيها الممكنتين وبقيمهما الثانوية

جدول (3) القيم الثانوية للقيم الممكنة للمفردة الرئيسية الثالثة : ماهية مر اجع التناغم

\begin{tabular}{|c|c|c|c|}
\hline 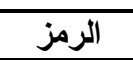 & القيم الثانوية & القيم الممكنة & المفردة الثالثة \\
\hline $1-1-3$ & مر اجع أسلوبية & \multirow{4}{*}{-1 1 مر اجع معمارية } & \multirow{14}{*}{3 - ماهية مر اجع التتاغم } \\
\hline $2-1-3$ & مر اجع تقنية & & \\
\hline 3-1-3 & مر اجع وظيفية & & \\
\hline $4-1-3$ & مر اجع هندسية & & \\
\hline $1-2-3$ & مر اجع كونية(طيات،انحناءات،.... & \multirow{10}{*}{ 3 -2 مراريع غير } & \\
\hline $2-2-3$ & مر اجع حضارية & & \\
\hline $3-2-3$ & مر اجع فلسفية & & \\
\hline $4-2-3$ & مر اجع مكانية & & \\
\hline $5-2-3$ & مر اجع نفسية & & \\
\hline $6-2-3$ & مر اجع حياتية(نباتية،حيو انية) & & \\
\hline $7-2-3$ & مر اجع فنية زمنية (نثر، شعر ، موسيقى، رقص) & & \\
\hline $8-2-3$ & مر اجع فنية شكلية (نحت، تصميم، ديكور ) & & \\
\hline $9-2-3$ & مر اجع علمية (قو انين الرياضيات، الفيزياء) & & \\
\hline $10-2-3$ & مر اجع عقائدية (طقوس الصلاة، الخشوع) & & \\
\hline
\end{tabular}

2 -3 -4 المفردة الرئيسية الر ابعة (الخصائص الثكلية للتناغم) : لقد ارتبطت المفردة الرئيسية الر ابعة بقيمتين ممكنتين

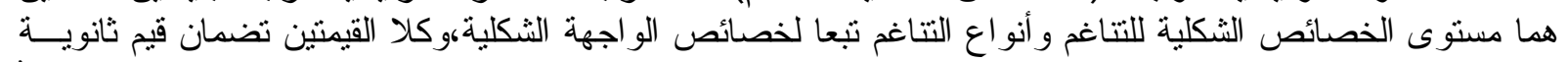

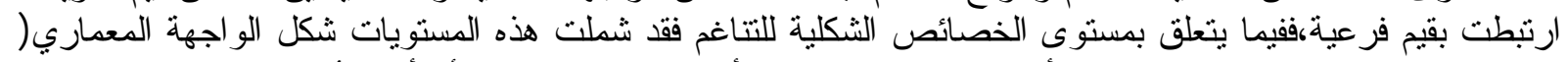

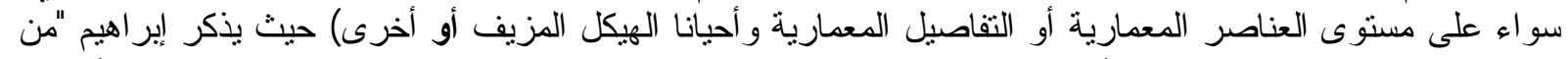

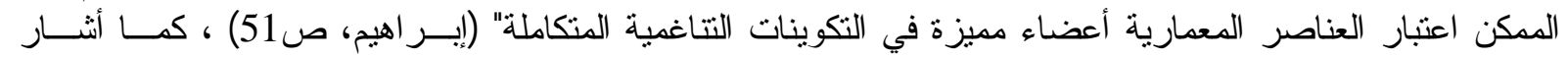

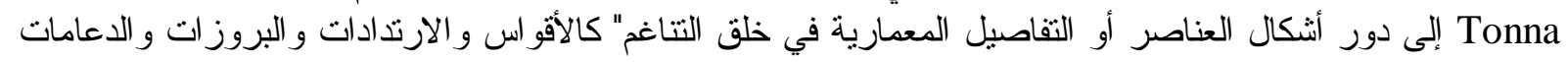

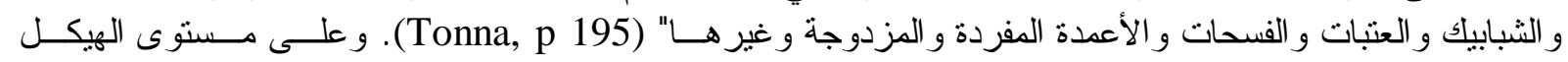




\section{$\begin{array}{llll}\text { Al-Rafidain Engineering } & \text { Vol.17 } & \text { No.5 } & \text { October } 2009\end{array}$}

الإنشائي المزيف (على مستوى الكل أو الجزء)يفصل الو اجهة تمامأ عن المبنى خلفها أو جزء منها، أو استخدام الأشكال

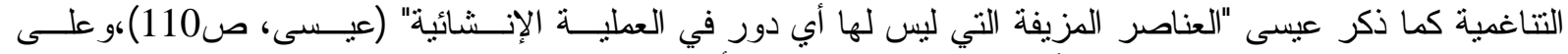

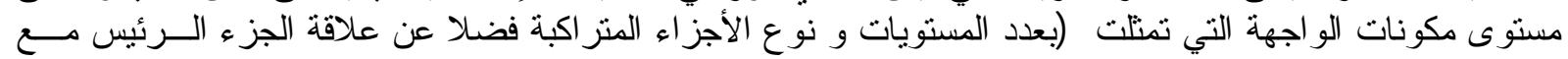

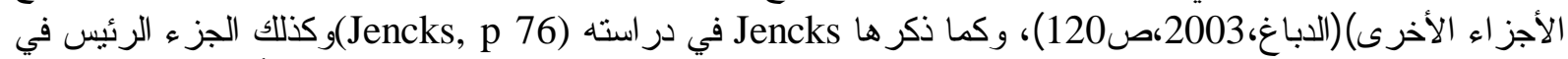

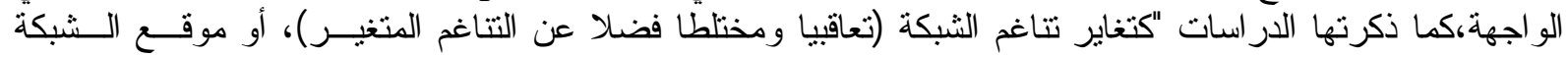
بالنسبة للأجز اء الأخرى أو علاقة التتاغم بالأجز اء الأخرى" (Ching, 1987, p 151).

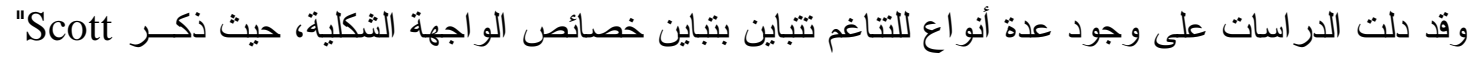

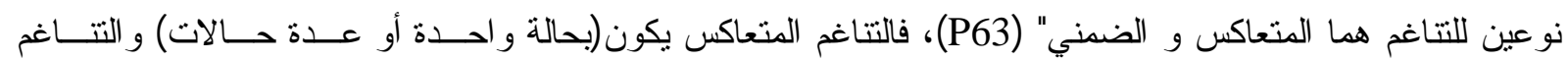

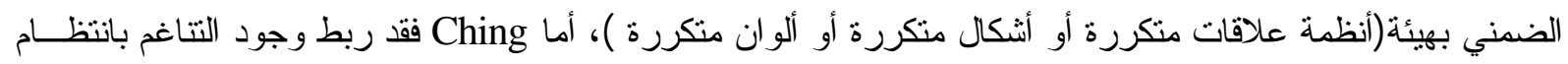

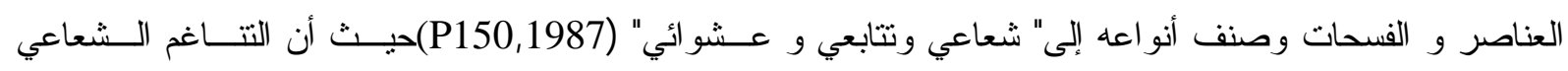
يكون(حول نقطة واحدة أو حول عدة نقاط)و التتاغم التتابعي (بأسلوب خطي و واحد أو عدة أسـاليب خطيــة) و التـــــاغم

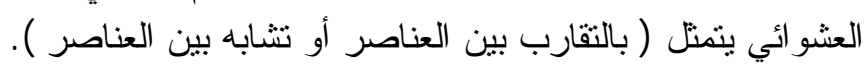

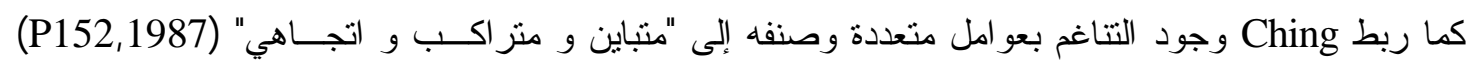

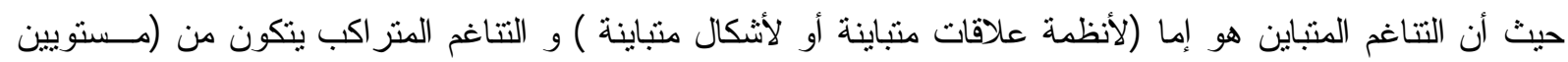

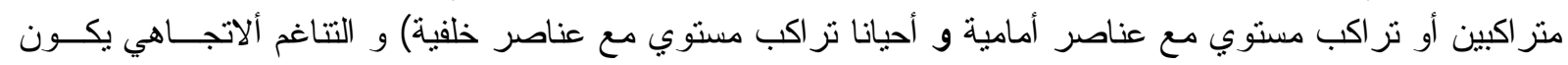
باتجاهين(عمودي أو أفقي). و الجدول (4) يوضح القيم الممكنة للمفردة الرئيسية الر ابعة بقيمها الممكنة و الثانوية وقيمهما الفرعية.

جدول (4) القيم الثانوية و الفرعية للقيم المكنة للمفردة الرئيسية الرابعة:الخصائص الثكلية للتناغم

\begin{tabular}{|c|c|c|c|c|}
\hline 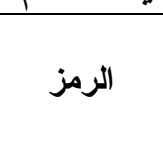 & القيم الفرعية & القيم الثانوية & الممكنة & الرائيسية \\
\hline $1-1-1-4$ & العناصر المعمارية & \multirow{5}{*}{ الو اجهة -1-1 الشكل } & \multirow{13}{*}{ 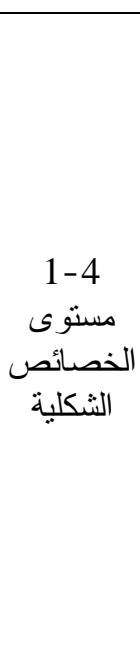 } & \multirow{21}{*}{ 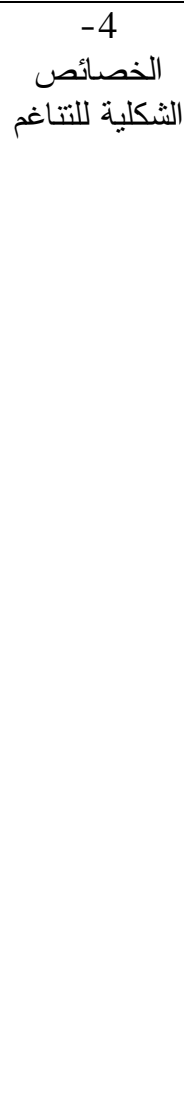 } \\
\hline $2-1-1-4$ & التفاصيل المعمارية & & & \\
\hline $3-1-1-4$ & الهيكل المزيف & & & \\
\hline 4- 1-1-4 & جزء من الهيكل المزيف & & & \\
\hline $5-1-1-4$ & أخرى & & & \\
\hline $1-2-1-4$ & عدد المستويات & \multirow{3}{*}{ 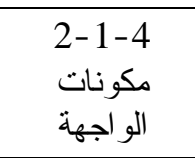 } & & \\
\hline 2-2-1-4 & نوع الأجز اء المتز اكبة & & & \\
\hline $3-2-1-4$ & علاقة الجزء الرئيس مع الأجز اء الأخرى & & & \\
\hline $1-3-1-4$ & تغاير تتاغم الثبكة(المتعاقب) & \multirow{5}{*}{ الرئيس في فيز 1 - 1 الجي } & & \\
\hline $2-3-1-4$ & تغاير تتاغم الثبكة(المختلط) & & & \\
\hline 3-3-1-4 & تغاير تتاغم الثبكة(المتغير) & & & \\
\hline 4- 3-1-4 & موقع الثبكة بالنسبة للأجز اء الأخرى & & & \\
\hline 5-3-1-4 & علاقة النتاغم بالأجز اء الأخرى & & & \\
\hline $1-1-2-4$ & حالة و احدة & \multirow{2}{*}{ 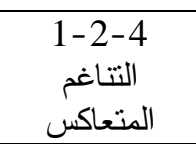 } & \multirow{8}{*}{ 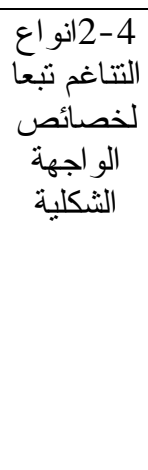 } & \\
\hline $2-1-2-4$ & عدة حالات & & & \\
\hline $1-2-2-4$ & أنظمة علاقات متكررة & \multirow{3}{*}{ 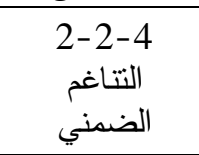 } & & \\
\hline $2-2-2-4$ & أثنكال متكررة & & & \\
\hline 3-2-2-4 & ألو ان متكررة & & & \\
\hline $1-3-2-4$ & حول نقطة و احدة & \multirow{2}{*}{ 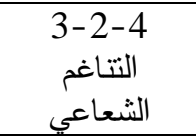 } & & \\
\hline $2-3-2-4$ & حول عدة نقاط & & & \\
\hline 1-4-2-4 & أسلوب خطي و احد & 4- $2-4$ & & \\
\hline
\end{tabular}


ثابت : التناغم وتواصلية التراث في النتاج المعماري الموصلي المعاصر

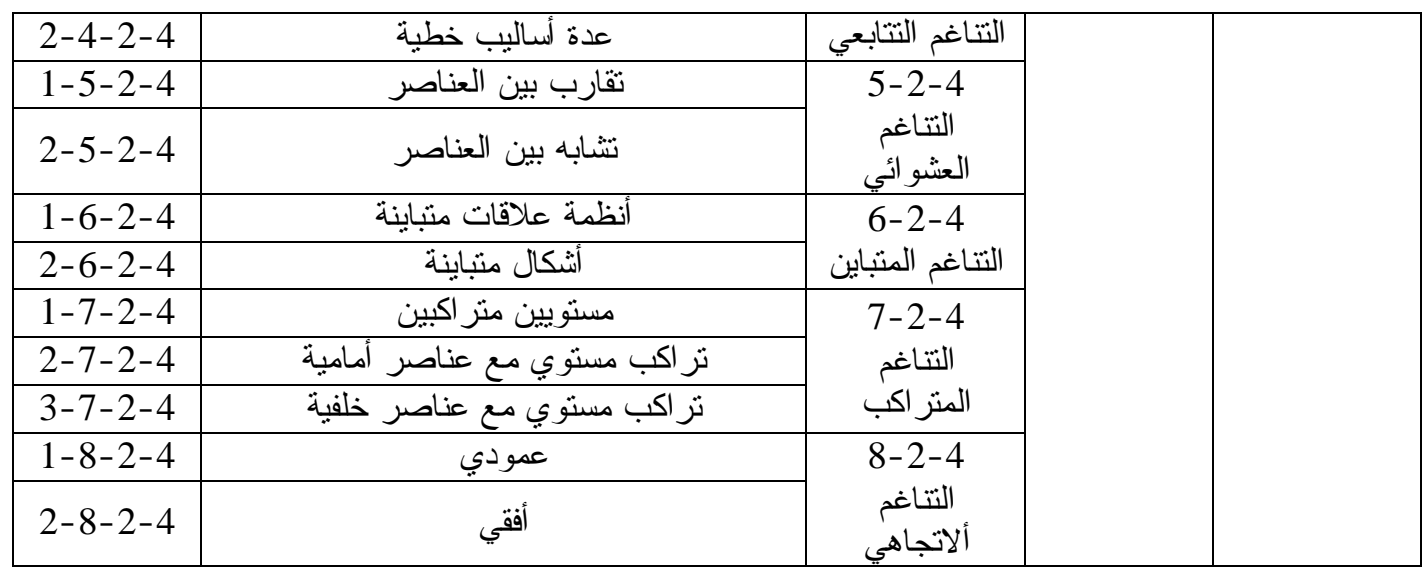

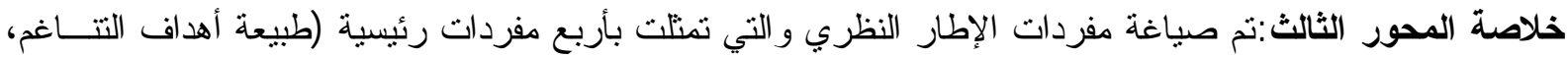

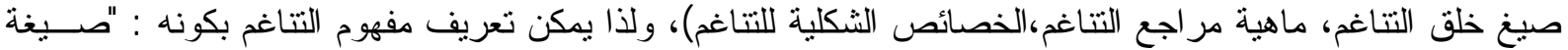

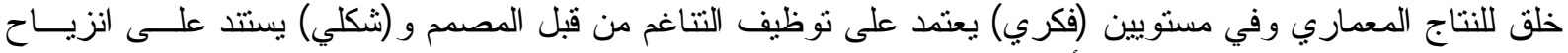

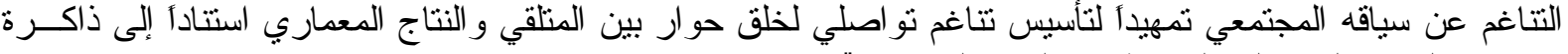

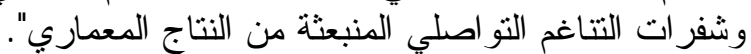
2 -4 المحور الرابع( التطبيق): انتقل البحث إلى مرحلة أخرى لحل المشكلة البحثية و المتمثلة بالتطبيق، حيث تم اعتماد

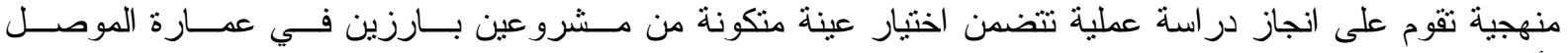
1 - مشروع مكتبة آثور باتيبال ومعهة الدراسات المسمارية في جامعة الموصل/2002/المكتبـ الاستـشاري كأنموذجين مهمين و هما :

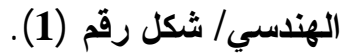

2 - مشروع شركة التأمين الوطنية / الموصل / 1966 / / المعماري رفعة الجادرجي / شكل رقم (2). 2 2 -1-1صياغة الفرضيات: لأجل إجر اء الدر اسة العملية لابد من صياغة الفرضية الفرضيات وبمحورين :

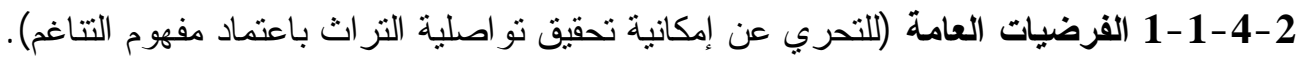

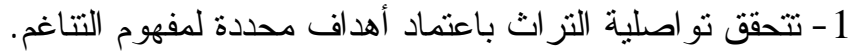

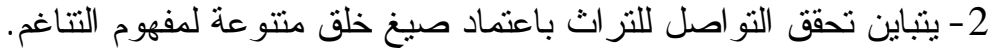

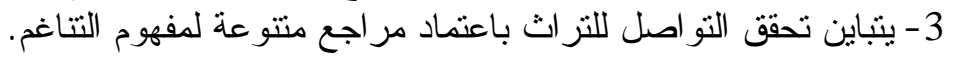

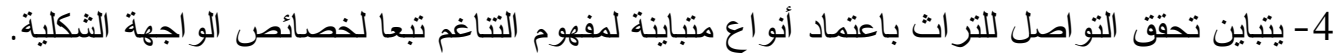

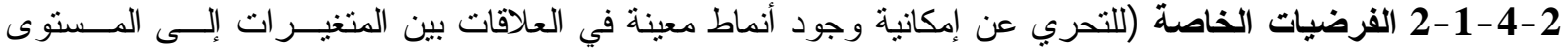
(التفصيلي). 1. ميل المعماريين لتحقيق كل من الأهداف (التواصلية و التأثيرية) لأجل نواصلية النزراث من خلال استثمار صيخ

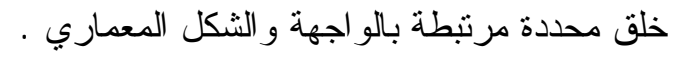

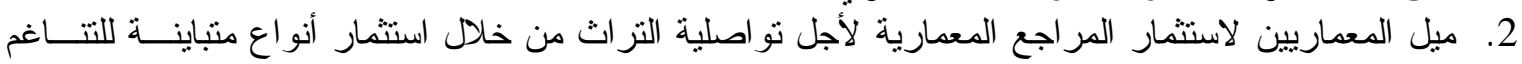
تبعا لخصائص الو اجهة الثكلية.

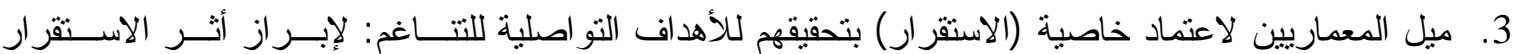

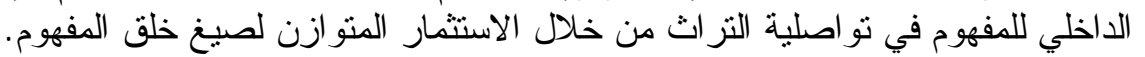

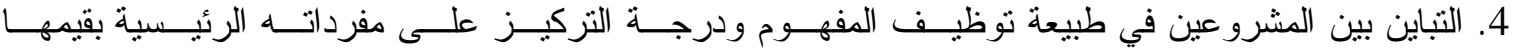

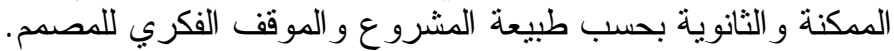

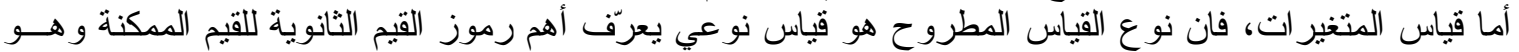

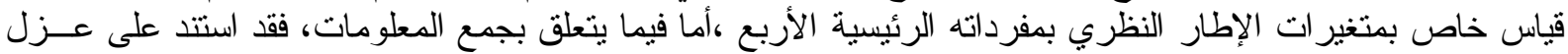

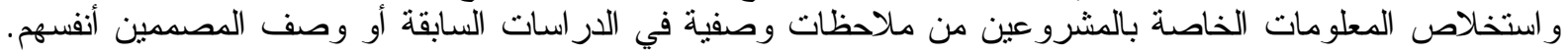

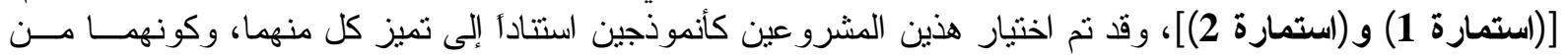
الأعمال الأكثر الأهمية في عمارة الموصل، وبارة التحديد من ناحية وضوح النوانين احي التتاغية فيها. 


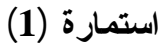

\begin{tabular}{|c|c|c|c|}
\hline \multicolumn{4}{|c|}{ استمارة قيّاس متغيرات المشروع الأول } \\
\hline الرمز & المكتب الاستشاري الهندسي /جامعة الموصل & 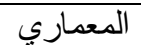 & \\
\hline B1 & مكتبة آثشور بانيبال و المعهد العالّي للار اسات المسمارية الموصل 2002 / جامعة & 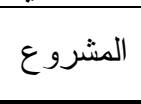 & تعريف المشروع \\
\hline
\end{tabular}

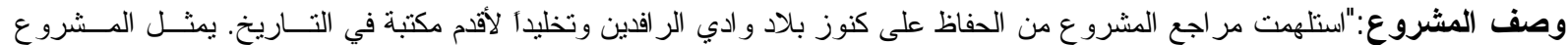

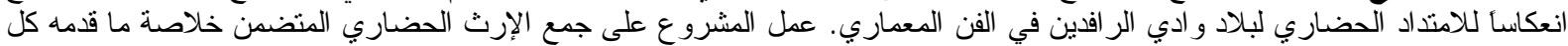

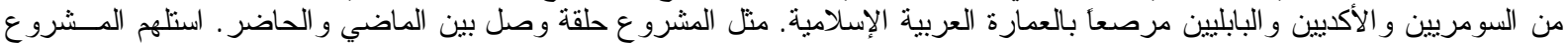

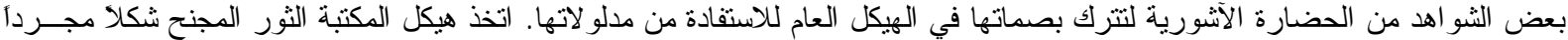

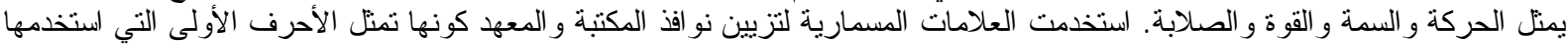

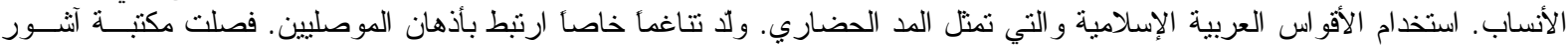

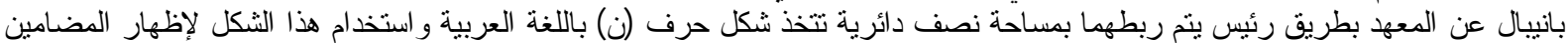

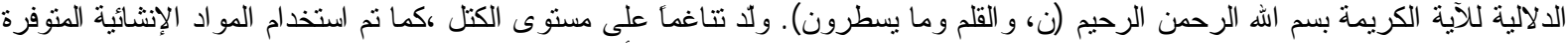

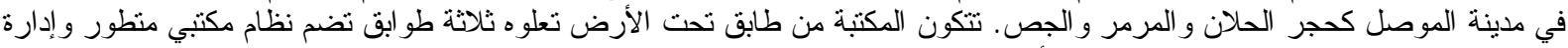

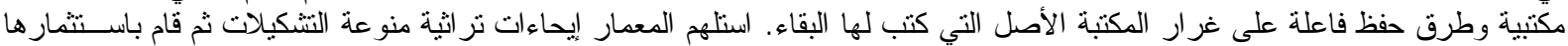

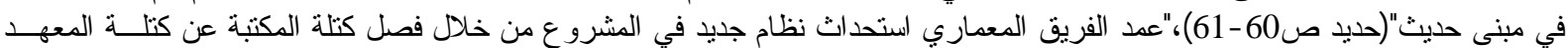

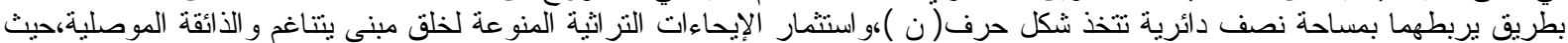

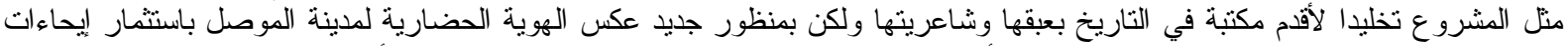

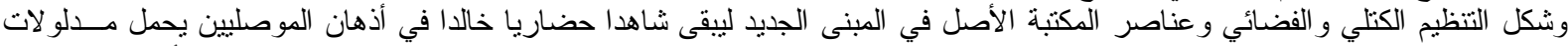

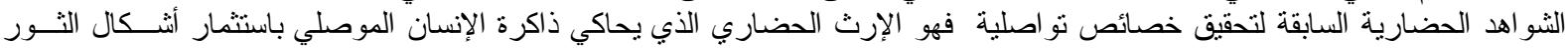

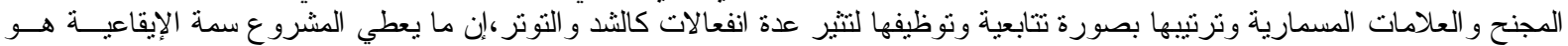

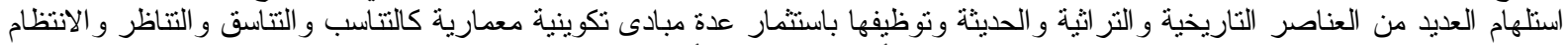

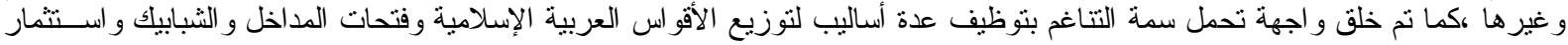

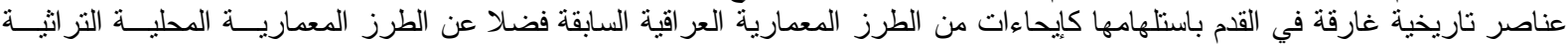

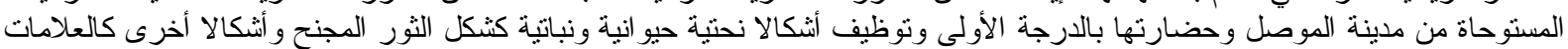

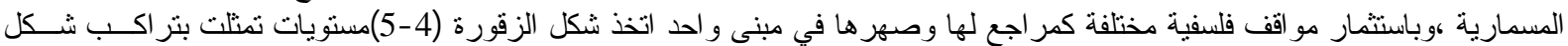

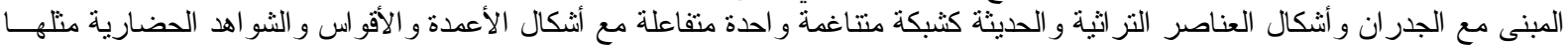

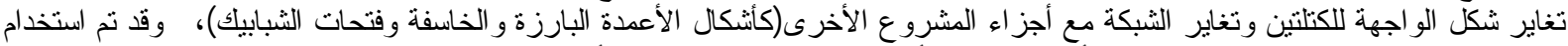

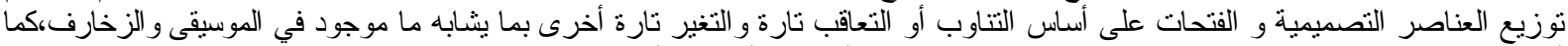

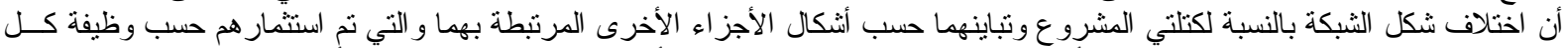

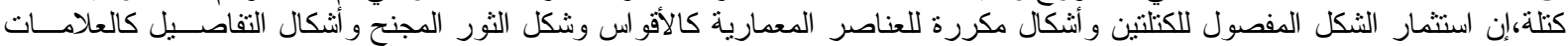

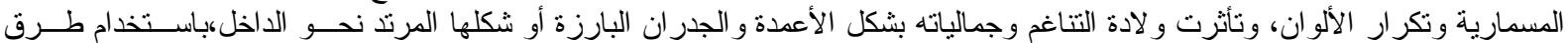
تكنولوجية وتقنيات حديثة في المشرو ع" .(وصف المصنمين للمشروع).

جدول (5 -1) يوضح قياس القيم الثانوية للقيم الممكنة للمفردات الرئيسية الأربع في المشروع الأول

\begin{tabular}{|c|c|c|c|c|c|}
\hline الرمز & القيما الثانوية & حالة الوصف & \multicolumn{2}{|c|}{ القيم الممكنة } & اللئسرداتي \\
\hline 3-1-1 & خلق حوار بين & 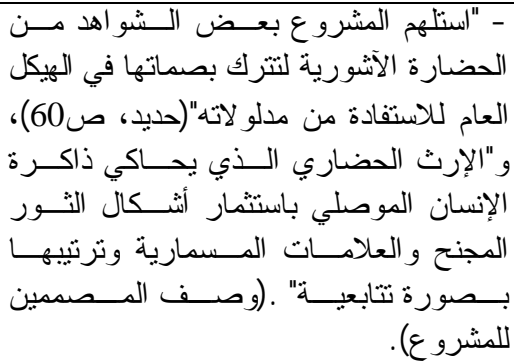 & \multirow[t]{2}{*}{ تو اصلية } & \multirow[b]{2}{*}{ 1- 1} & \multirow[t]{2}{*}{1 أهداف } \\
\hline 4-1-1 & تحقيق خصائص & 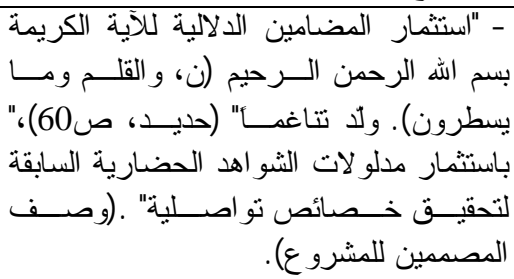 & & & \\
\hline
\end{tabular}


ثابت : التناغم وتواصلية التراث في النتاج المعماري الموصلي المعاصر

\begin{tabular}{|c|c|c|c|c|c|}
\hline الرمز & القيم الثانوية & حالة الوصف & \multicolumn{2}{|c|}{ القيم الممكنة } & اللمفردات \\
\hline 2-2- 1 & التوتز و الثند & 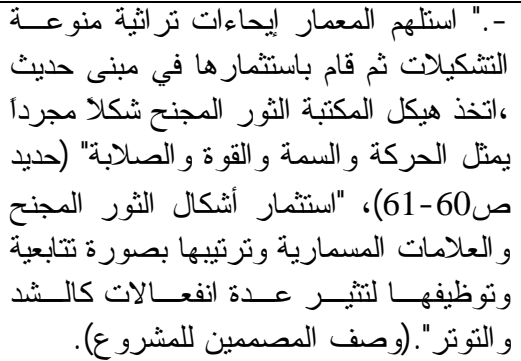 & تأثثرية & 2- 1 & \\
\hline 2-3- 1 & و الاستمر ارية & 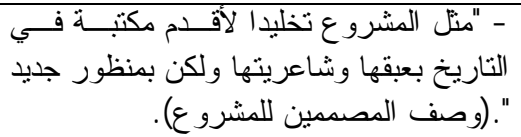 & ترميزية & 3- 1 & \\
\hline $1-4-1$ & جمالية تعبير ات & 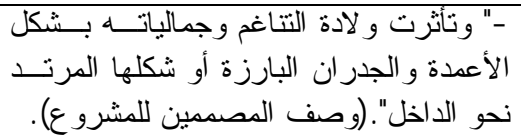 & تجميلية & 4- 1 & \\
\hline $1-6-1$ & تلائم الذوق النظمة جديدة & 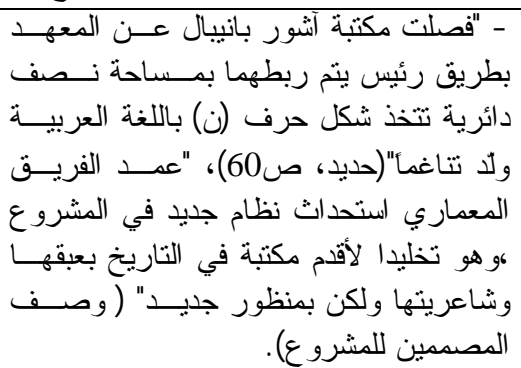 & ابتكارية & 6- 1 & \\
\hline $1-8-1$ & إقامة هوية ما & 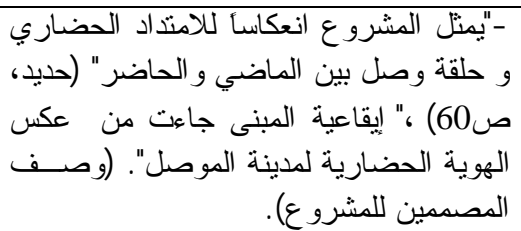 & سياسية & 8- 1 & \\
\hline 2-9- 1 & أهداف عامة خاصة & 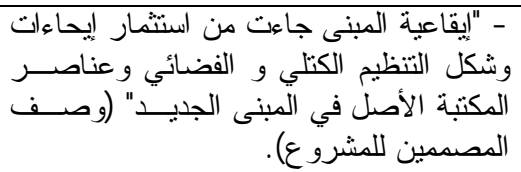 & تصميمية & 9- 1 & \\
\hline $1-1-2$ & العناصر المعمارية & 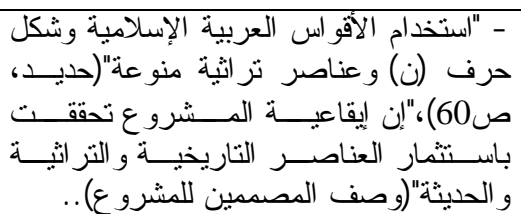 & & & 2 - صلثغ \\
\hline $2-1-2$ & التفاصيل المعمارية & 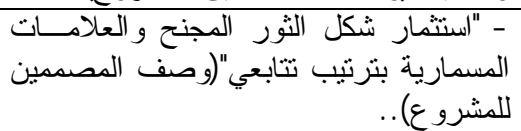 & المعالثكل & $1-2$ & \\
\hline $3-1-2$ & مبادئ التكوين & 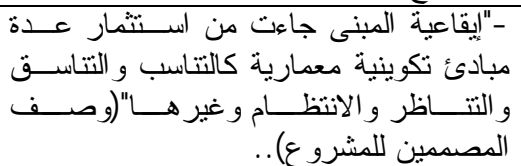 & & & \\
\hline $1-2-2$ & خاص بالمظهر & 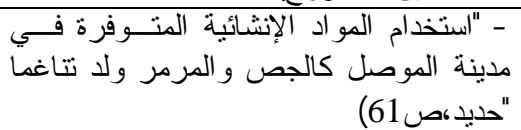 & نبطة & & \\
\hline $2-2-2$ & خاص بالتكوين & 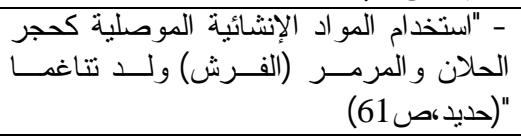 & & & \\
\hline
\end{tabular}




\begin{tabular}{|c|c|c|c|c|c|}
\hline 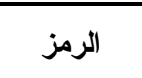 & القيم الثانوية & حالة الوصف & \multicolumn{2}{|c|}{ القيم الممكنة } & المئيسردية \\
\hline $1-3-2$ & كل الهيكل الحقيقي & 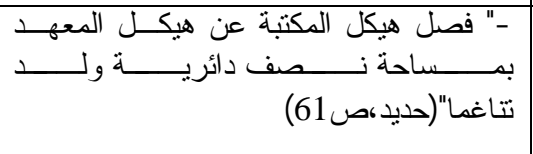 & المرتبطة & $3-2$ & \\
\hline $1-4-2$ & كلي & 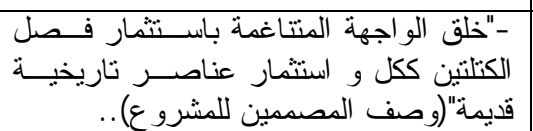 & \multirow{3}{*}{ بالو اجهة } & \multirow{3}{*}{ 4- 2} & \\
\hline $2-4-2$ & جزئي & 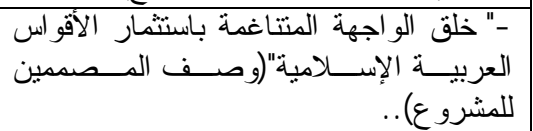 & & & \\
\hline $3-4-2$ & أخرى & 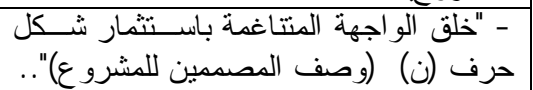 & & & \\
\hline $1-1-3$ & أسلوبية & 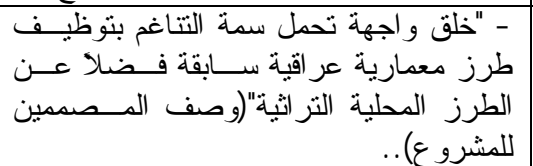 & \multirow{3}{*}{ معمارية - معاجة } & \multirow{3}{*}{$1-3$} & \multirow{8}{*}{3 - ماهية } \\
\hline $2-1-3$ & تقنية & 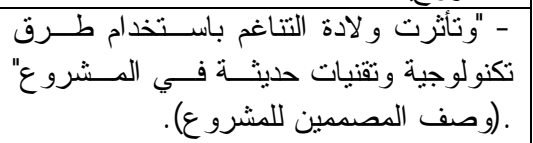 & & & \\
\hline 4- $1-3$ & هندسية & 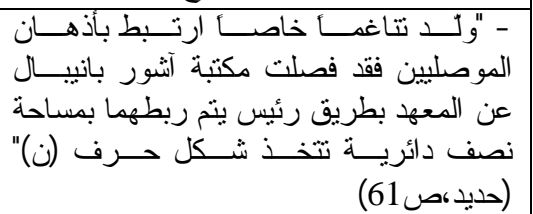 & & & \\
\hline $2-2-3$ & حضارية & 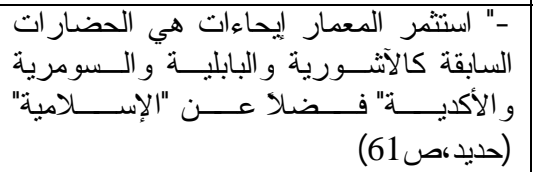 & \multirow{5}{*}{ معمارية غير } & \multirow{5}{*}{$2-3$} & \\
\hline $3-2-3$ & فلسفية & 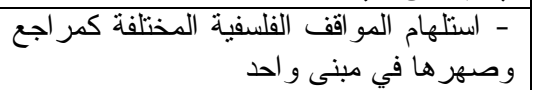 & & & \\
\hline $7-2-3$ & فنية زمنية & 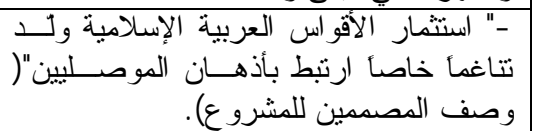 & & & \\
\hline $8-2-3$ & فنية شكلية & 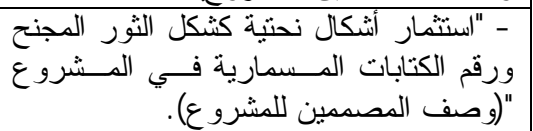 & & & \\
\hline $10-2-3$ & عقائدية & 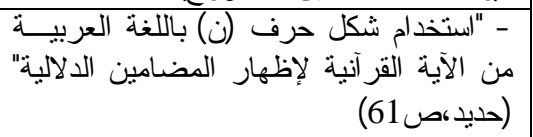 & & & \\
\hline $1-1-1-4$ & العناصر المعمارية & 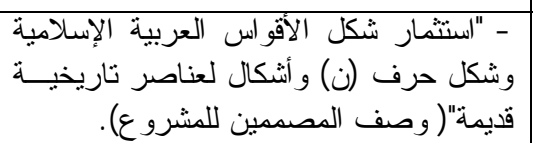 & \multirow{2}{*}{$\begin{array}{l}\text { الو اجهلة } 1-1-4 \\
\text { المعماري }\end{array}$} & \multirow[t]{5}{*}{ 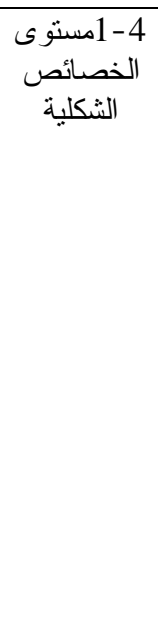 } & \multirow{5}{*}{ الخصائصل } \\
\hline 2-1-1- 4 & التفاصيل المعمارية & 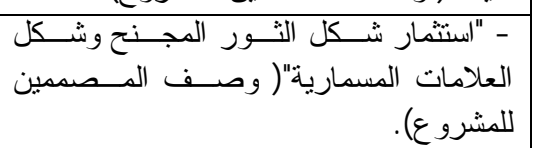 & & & \\
\hline 1- 2-1- 4 & (4 -5) مستويات & 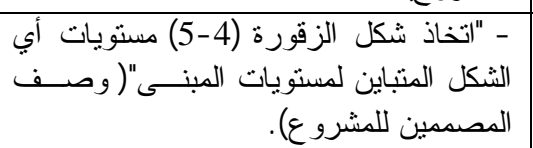 & \multirow{3}{*}{ 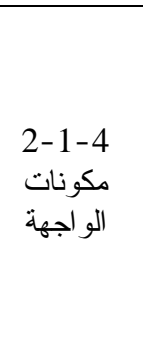 } & & \\
\hline $2-2-1-4$ & وجر اكب شبكة & 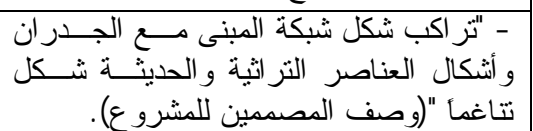 & & & \\
\hline $3-2-1-4$ & علاقة الكتلة & 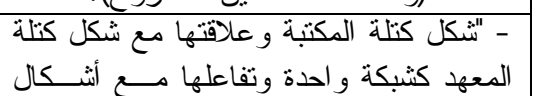 & & & \\
\hline
\end{tabular}


ثابت : التناغم وتواصلية التراث في النتاج المعماري الموصلي المعاصر

\begin{tabular}{|c|c|c|c|c|c|}
\hline 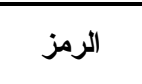 & القيم الثُانويةً & حالة الوصف & \multicolumn{2}{|c|}{ القيم الممكنة } & اللرئيسية \\
\hline & العناصر الأخرى & 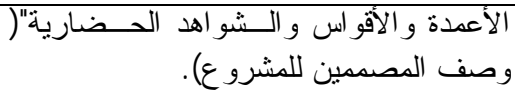 & & & \\
\hline $2-3-1-4$ & الثبكة(المختلط) تخاغم) & 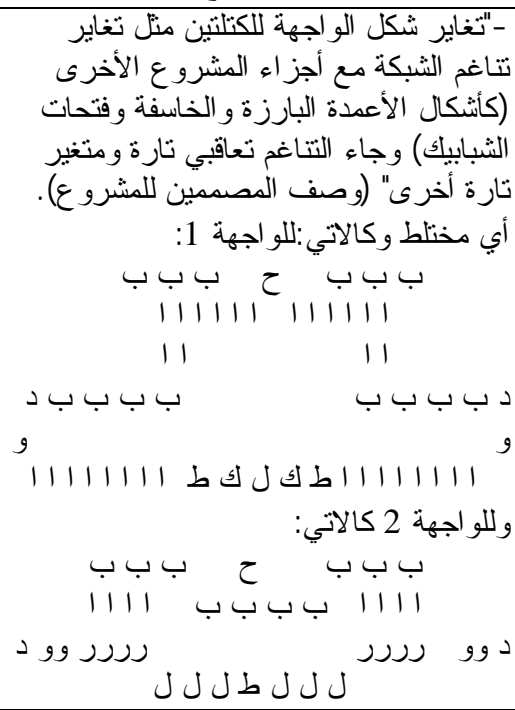 & \multirow[t]{3}{*}{ 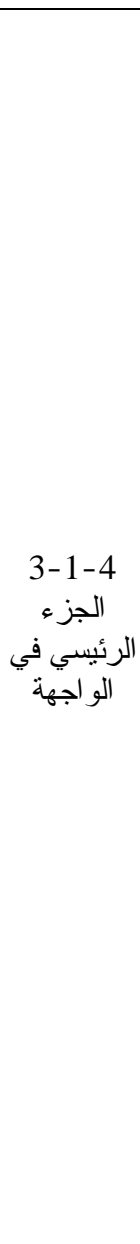 } & & \\
\hline 4- 3- $1-4$ & و النتاف الثنبكة للكنل & 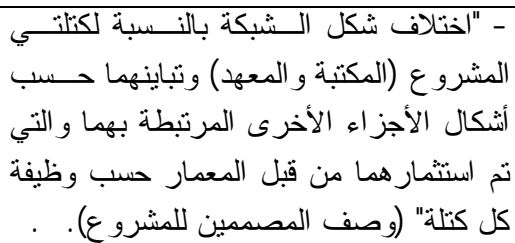 & & & \\
\hline $5-3-1-4$ & بالأعمدة والجم الثبكة & 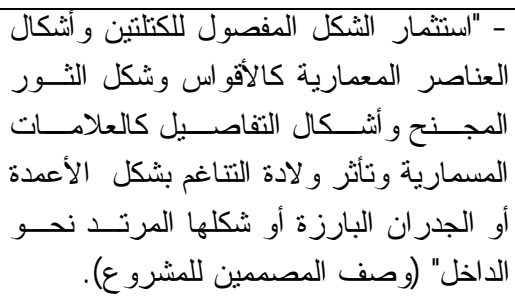 & & & \\
\hline $2-1-2-4$ & عدة حالات & 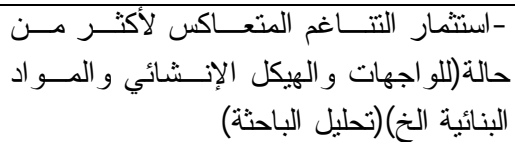 & المتعاكس & \multirow{8}{*}{ 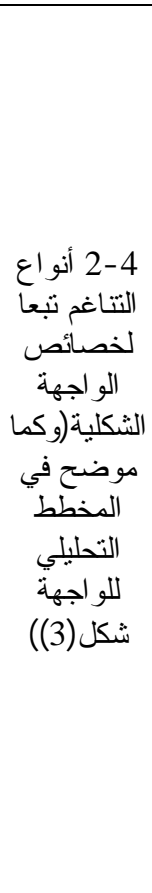 } & \\
\hline $1-1-2-4$ & أنظمة علاقات & 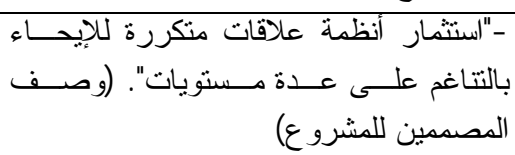 & \multirow{3}{*}{ 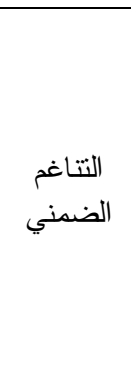 } & & \\
\hline $2-1-2-4$ & أنثكال متكررة & 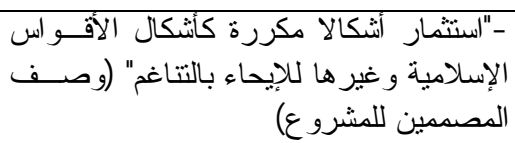 & & & \\
\hline 3- $1-2-4$ & ألو ان متكررة & 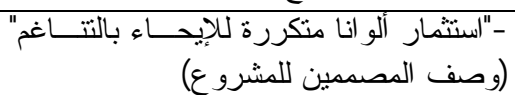 & & & \\
\hline 2- $4-2-4$ & عدة أساليب خطية & -استخدام عدة أساليب خطية(تحليل الباحثة) & التتابعي & & \\
\hline $1-7-2-4$ & تز اكب مستوي معر أمامية. & و الفتحات استخدلم الطبقات المباحثة). & المتر اكب التمب & & \\
\hline $1-8-2-4$ & 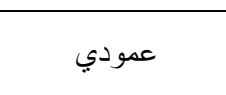 & 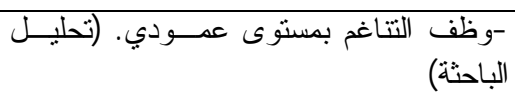 & \multirow{2}{*}{ 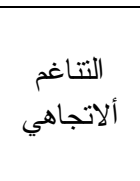 } & & \\
\hline $2-8-2-4$ & أفقي & الباحثة). & & & \\
\hline
\end{tabular}




\section{$\begin{array}{llll}\text { Al-Rafidain Engineering } & \text { Vol.17 } & \text { No.5 } & \text { October } 2009\end{array}$}

(2) (2) (2)

\begin{tabular}{|c|c|c|c|}
\hline \multicolumn{4}{|c|}{ استمارة قياس متغير ات المشروع الثاني } \\
\hline الرمز & رفعة الجادرجي & المعماري & \multirow{2}{*}{ تعريف المشروع } \\
\hline B2 & مبنى شركة التأمين الوطنية / الموصل / 1966 & 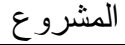 & \\
\hline \multicolumn{4}{|c|}{ الوصف الوصف } \\
\hline
\end{tabular}

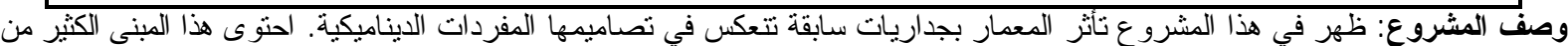

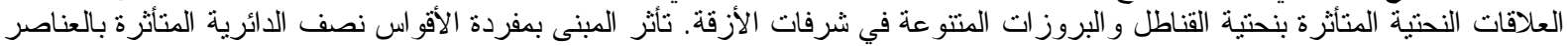

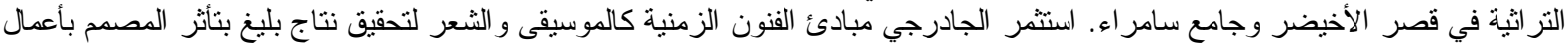

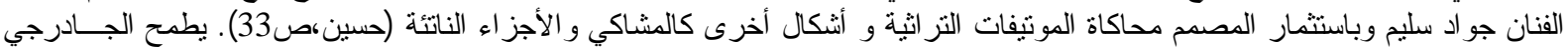

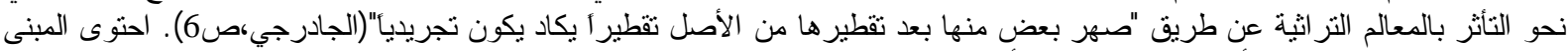

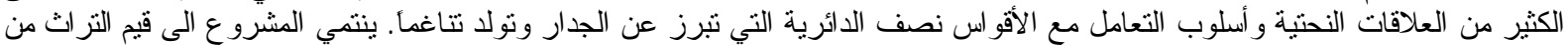

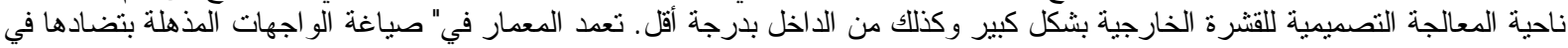

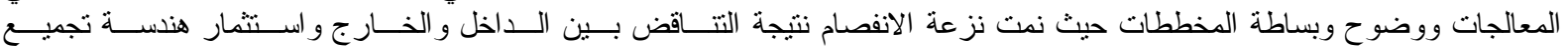

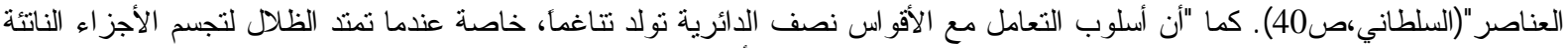

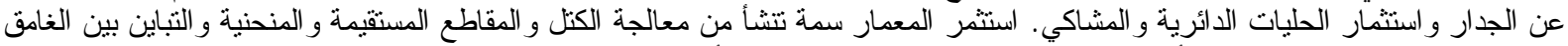

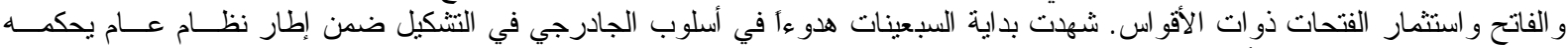

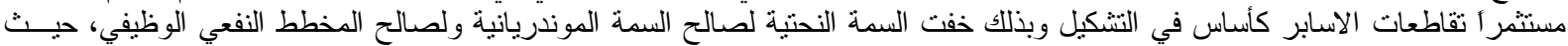

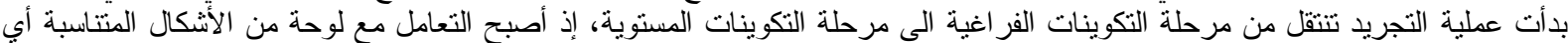

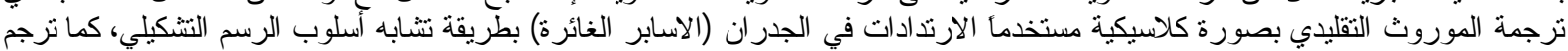

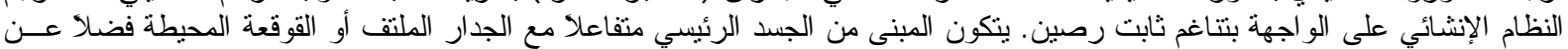

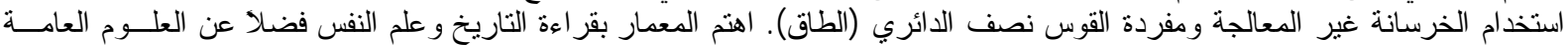

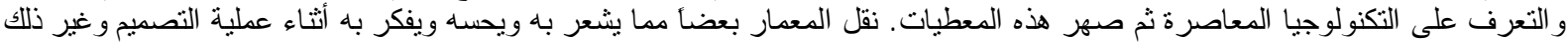

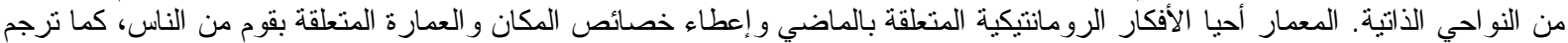

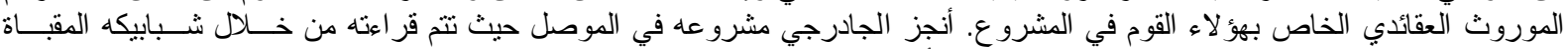

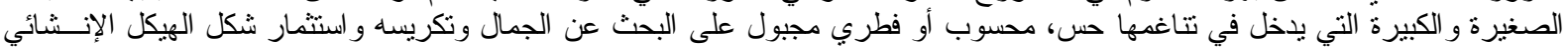

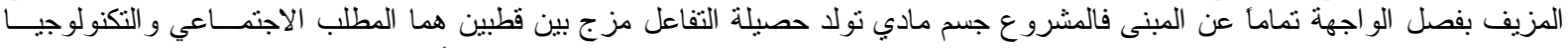

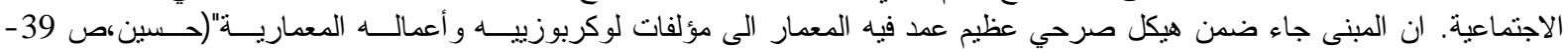

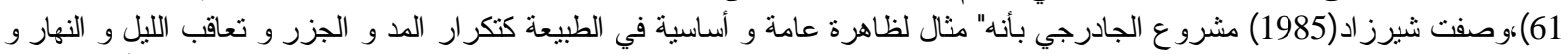

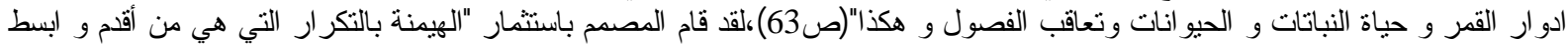

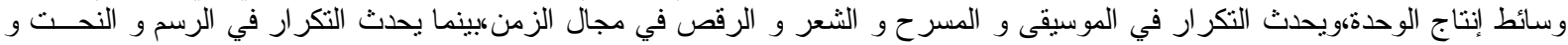

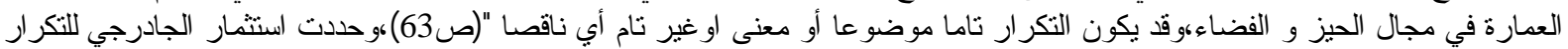

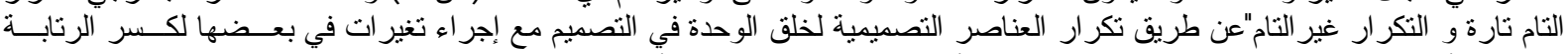

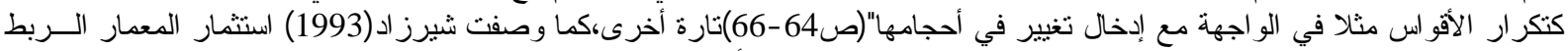

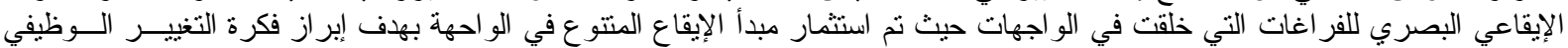

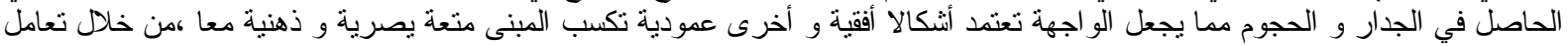

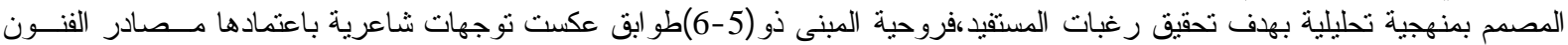

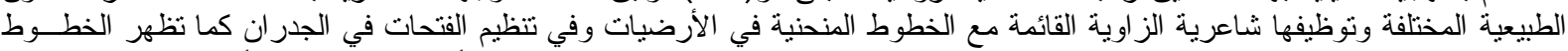

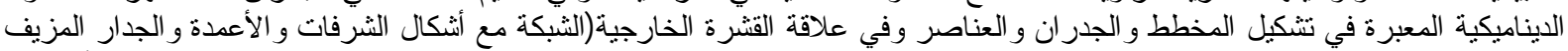

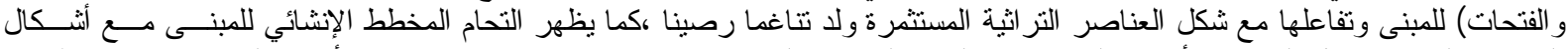

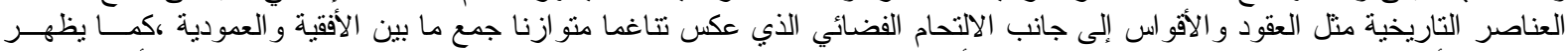

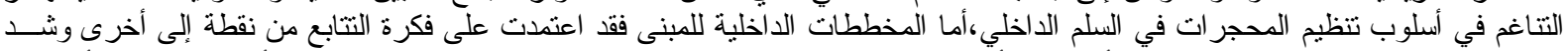

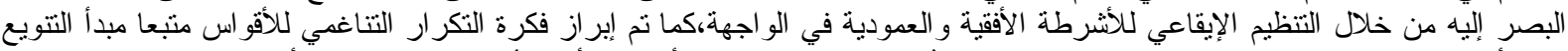

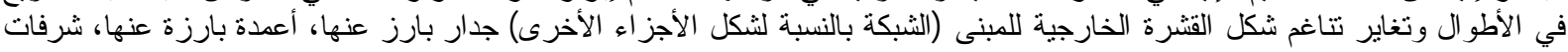

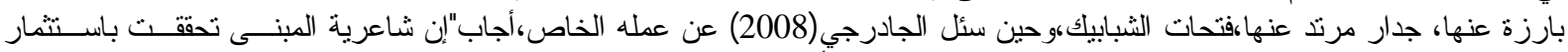

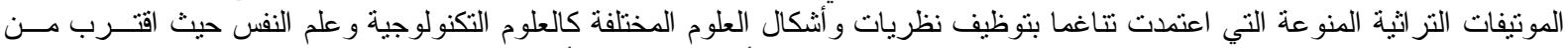

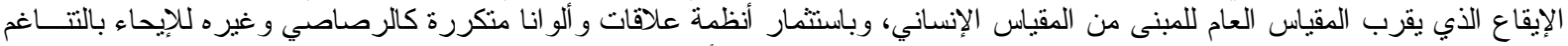

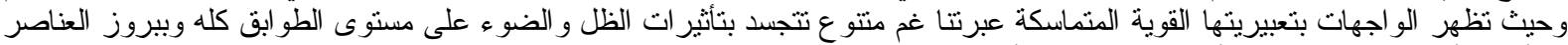
كالأعمدة أو ارتدادها وتوظيف أنثكالا متكررة كالأقو اس و غير ها ليتسم المبنى بالتتاغم ". 
ثابت : التناغم وتواصلية التراث في النتاج المعماري الموصلي المعاصر

جدول (5 -2) يوضح قياس القيم الثانوية للقيم الممكنة للمفردات الأربع الرئيسية في المشروع الثاني

\begin{tabular}{|c|c|c|c|c|c|}
\hline الرمز ل & القيم الثانوية & حالة القياس & & القيم المككنة & المفئيسة \\
\hline $1-1-1$ & نقل معنى خاص & 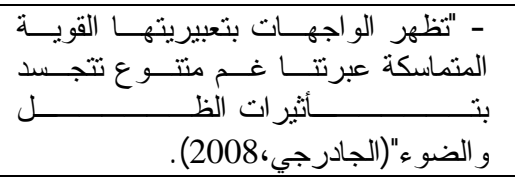 & \multirow{4}{*}{ تو اصلية } & \multirow{4}{*}{$1-1$} & \multirow{11}{*}{ ألتاغداف 1 - طبيعة } \\
\hline $2-1-1$ & فكرية شخصنة فلسفة & 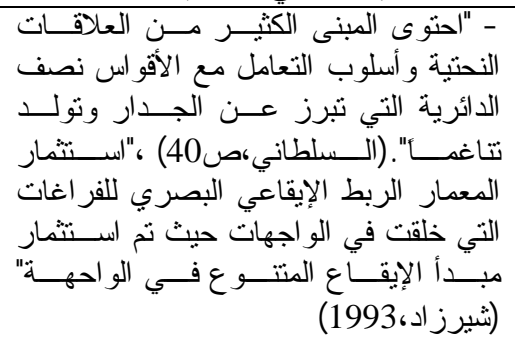 & & & \\
\hline $3-1-1$ & خلق النتاج و المتلقي & 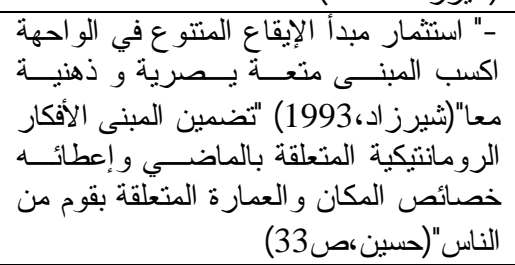 & & & \\
\hline 4- $1-1$ & تحقيق خصلية ألتص & 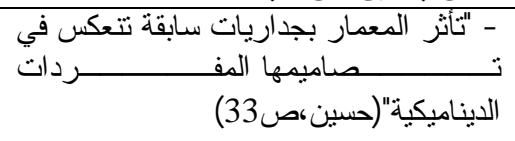 & & & \\
\hline $1-2-1$ & المالصدارة وعنصر & 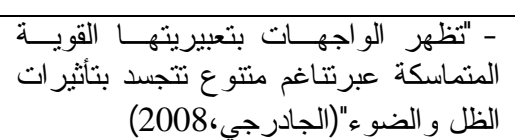 & \multirow[b]{2}{*}{ تأثيْيرية } & \multirow[b]{2}{*}{$2-1$} & \\
\hline $2-2-1$ & التشتر و الثند & 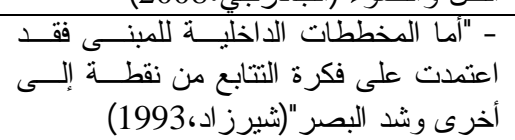 & & & \\
\hline $2-3-1$ & و الاستئمر ارية & 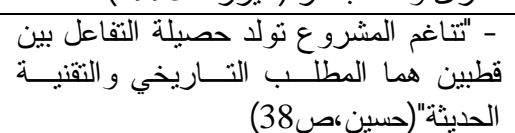 & ترميزية & 3- 1 & \\
\hline $1-4-1$ & جمالية خاصنية & 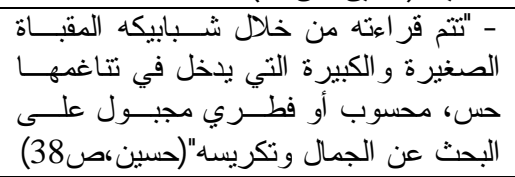 & \multirow[t]{2}{*}{ تجميلية } & \multirow[t]{2}{*}{ 4- 1} & \\
\hline 2-4- 1 & جمالية تعبير اتة & "الشيرز اد، 1993) & & & \\
\hline $1-6-1$ & الذبتوة أنظمة & 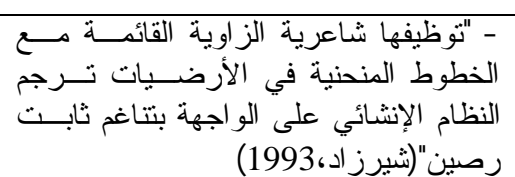 & ابتكارية & 6- 1 & \\
\hline 2-9-1 & خاصة بالمستفيد & 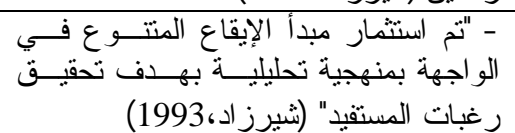 & تصميمية & 9- 1 & \\
\hline $1-1-2$ & 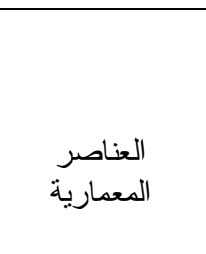 & 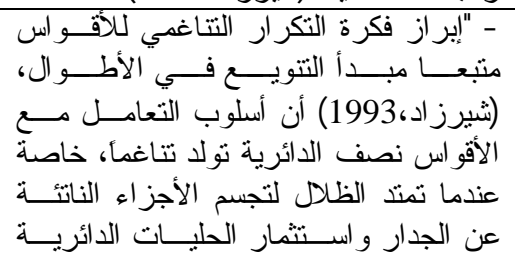 & 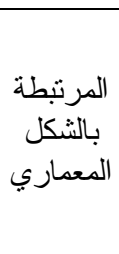 & & خلتق \\
\hline
\end{tabular}


$\begin{array}{llll}\text { Al-Rafidain Engineering } & \text { Vol.17 } & \text { No.5 } & \text { October } 2009\end{array}$

\begin{tabular}{|c|c|c|c|c|c|}
\hline 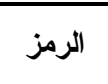 & القيم الثانوية & حالة القياس & & القيم الممكنة & الرئيسبةد \\
\hline & & و المشاكي"(حسين،ص36) & & \multirow{3}{*}{$1-2$} & \\
\hline $2-1-2$ & 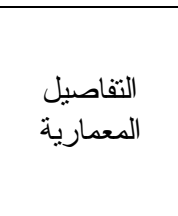 & 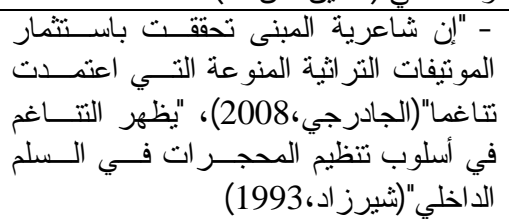 & & & \\
\hline $3-1-2$ & مبادئ التكوين & 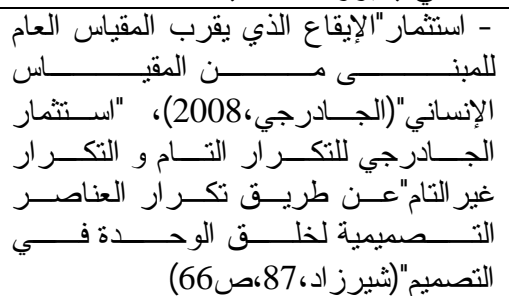 & & & \\
\hline $1-2-2$ & خاصة بالمظهر & 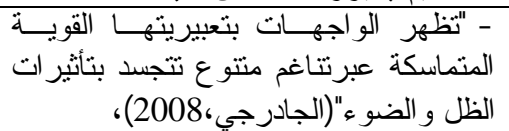 & \multirow{2}{*}{ البالمو اد البطة } & \multirow[b]{2}{*}{$2-2$} & \\
\hline $2-2-2$ & خاصة بالتكوين & 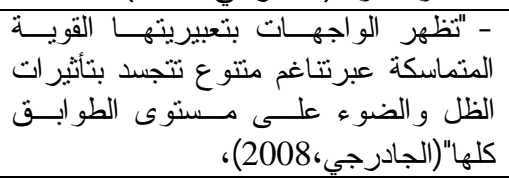 & & & \\
\hline $1-3-2$ & كل الهيكل & 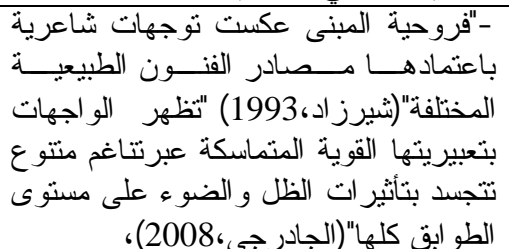 & \multirow[t]{2}{*}{ الإلمرتبطة } & \multirow[t]{2}{*}{ 3- 2} & \\
\hline 3-3-2 & أخرى & 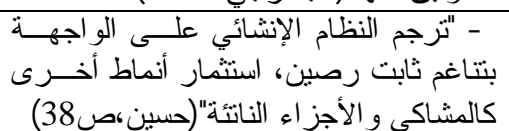 & & & \\
\hline $1-4-2$ & 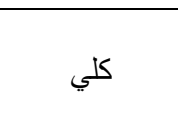 & 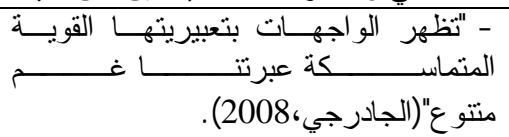 & \multirow{4}{*}{ بالو اجهة } & \multirow{4}{*}{ 4- 2} & \\
\hline 2-4- 2 & جزئي & 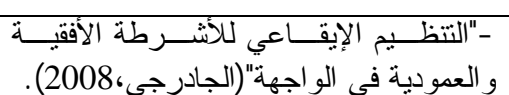 & & & \\
\hline 3-4- 2 & أخرى & 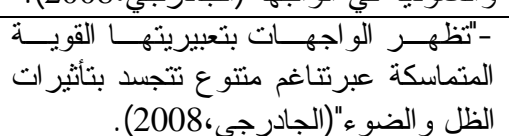 & & & \\
\hline 3-4- 2 & أخرى & 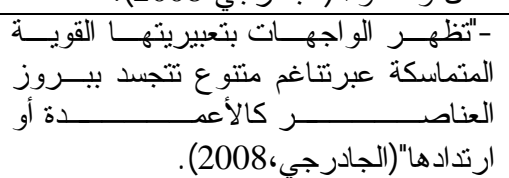 & & & \\
\hline $1-1-3$ & أسلوبية & 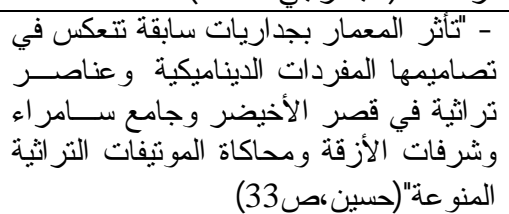 & \multirow[t]{3}{*}{ معمارية - مراجة } & \multirow[t]{3}{*}{$1-3$} & \multirow[t]{3}{*}{3 - ماهية } \\
\hline $2-1-3$ & تقنية & 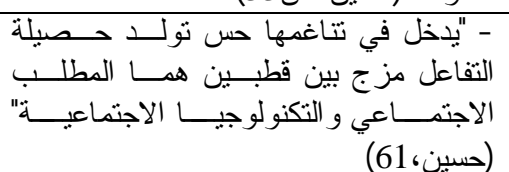 & & & \\
\hline $3-1-3$ & وظيفية & 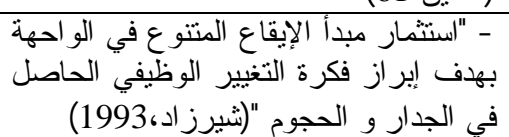 & & & \\
\hline
\end{tabular}


ثابت : التناغم وتواصلية التراث في النتاج المعماري الموصلي المعاصر

\begin{tabular}{|c|c|c|c|c|c|}
\hline الرمز & القيم الثُانويةً & حالة القياس & & القيم الممكنة & الرئيسية \\
\hline 4- $1-3$ & هندسية & 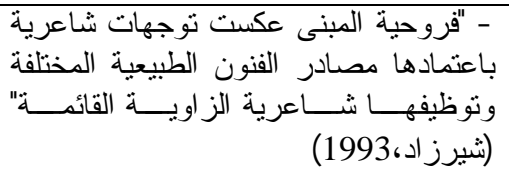 & & & \\
\hline $1-2-3$ & كونية & 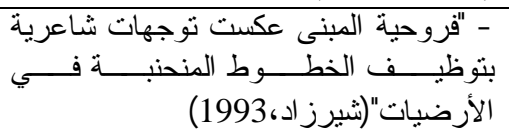 & \multirow{8}{*}{ معراجع } & \multirow{8}{*}{$2-3$} & \\
\hline $2-2-3$ & حضارية & 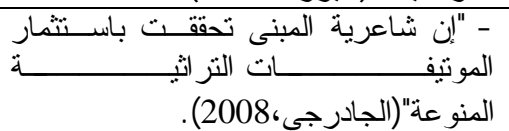 & & & \\
\hline 4- $2-3$ & مكانية & 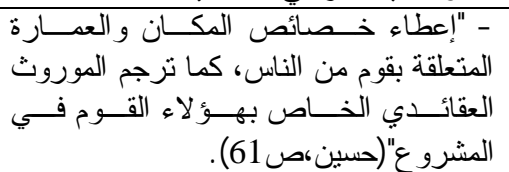 & & & \\
\hline $5-2-3$ & نفسية & 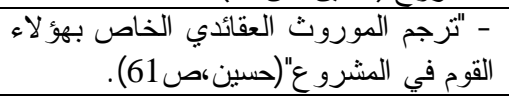 & & & \\
\hline $6-2-3$ & حباتية & 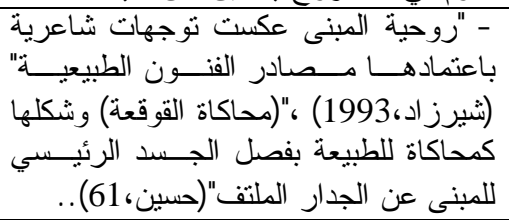 & & & \\
\hline $7-2-3$ & فنية زمنية & 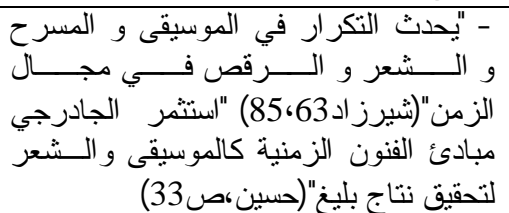 & & & \\
\hline $8-2-3$ & فنية شكلية & 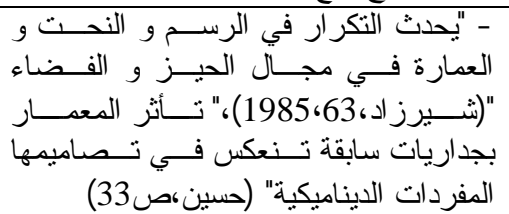 & & & \\
\hline $9-2-3$ & علمية & 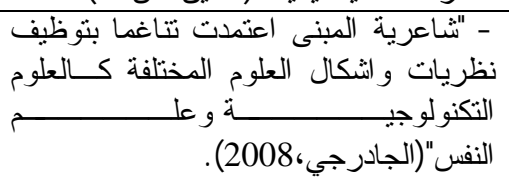 & & & \\
\hline $\begin{array}{r}-1-1-4 \\
1\end{array}$ & 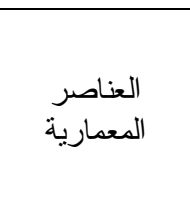 & 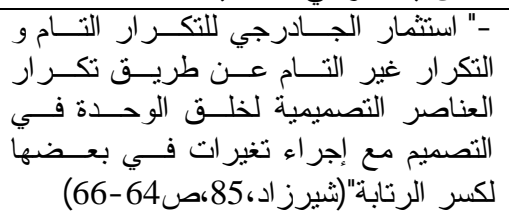 & \multirow{4}{*}{ 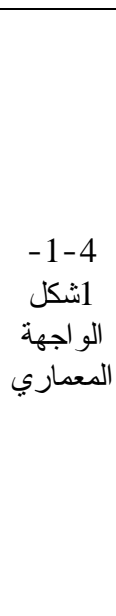 } & \multirow[t]{5}{*}{ 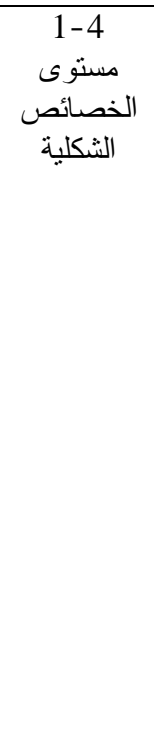 } & \multirow[t]{5}{*}{ الخصائصة 4} \\
\hline $\begin{array}{c}-1-1-4 \\
2\end{array}$ & 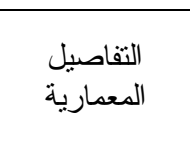 & 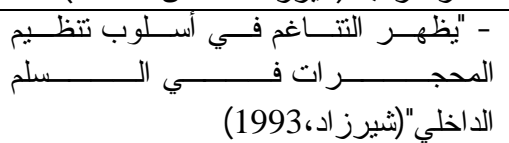 & & & \\
\hline $\begin{array}{c}-1-1-4 \\
3\end{array}$ & الهيكل المزيف & 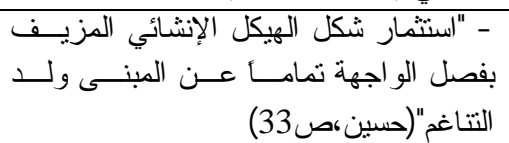 & & & \\
\hline $\begin{array}{c}-1-1-4 \\
5\end{array}$ & أخرى & 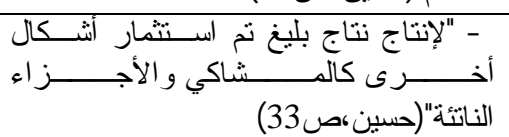 & & & \\
\hline - 2- $1-4$ & (5 -6)مستويات & 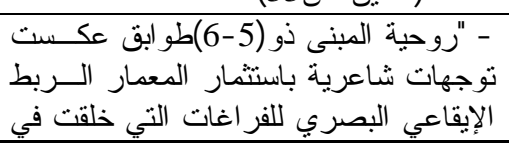 & $\begin{array}{l}\text { الو اجونات } 1-4 \\
\text { الو } 1-4\end{array}$ & & \\
\hline
\end{tabular}




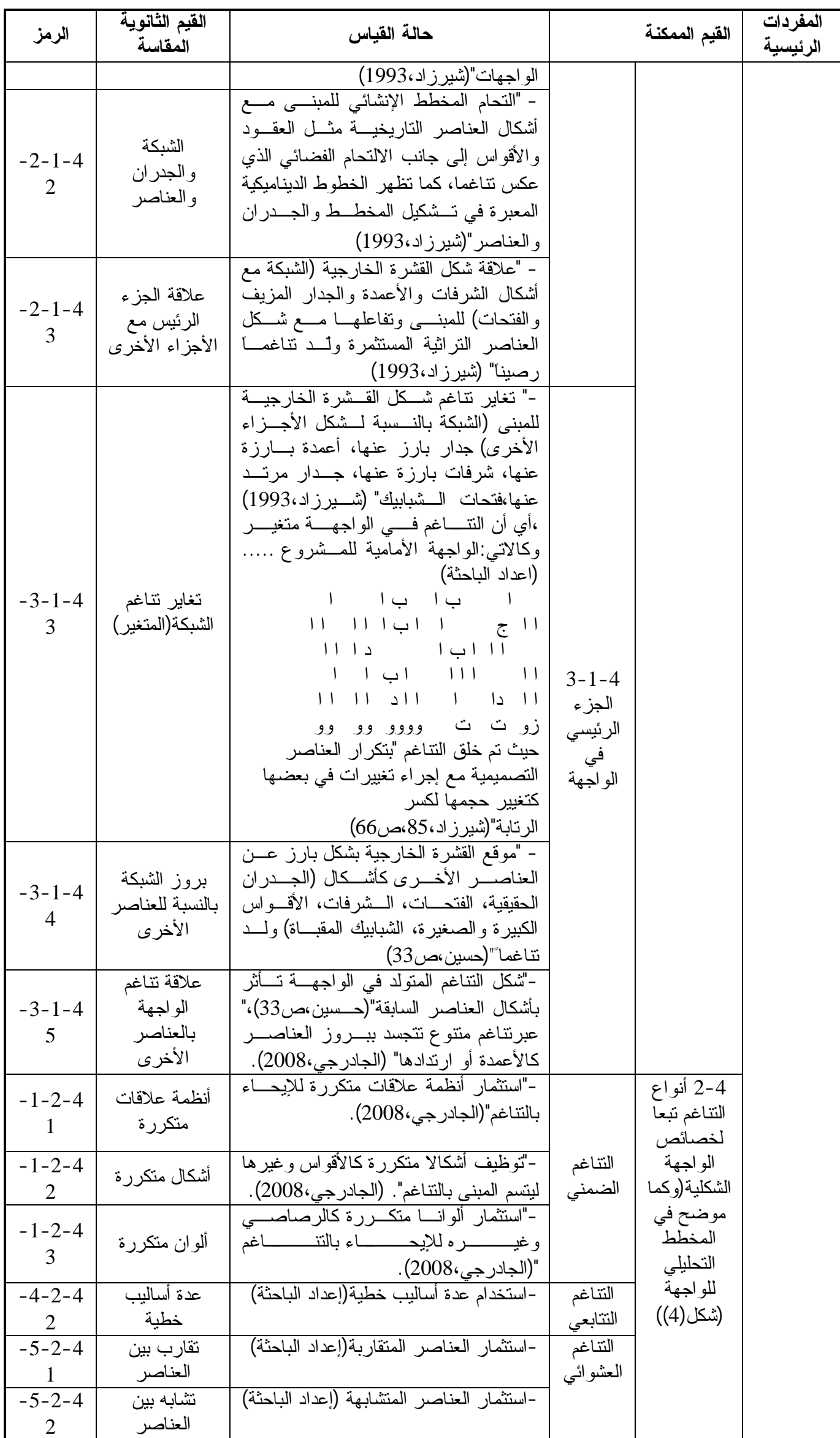


ثابت : التناغم وتواصلية التراث في النتاج المعماري الموصلي المعاصر

\begin{tabular}{|c|c|c|c|c|c|}
\hline الرمز & القيم الثُانويةً & حالة القياس & & القيم الممكنة & المفئيسية \\
\hline $\begin{array}{c}-6-2-4 \\
1\end{array}$ & أنظمة علاقات & الباحثة) استخدام أنظمة علاقات متباينة (إعـــداد & \multirow[t]{2}{*}{ 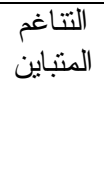 } & & \\
\hline $\begin{array}{c}-6-2-4 \\
2\end{array}$ & أشثكال منباينة & 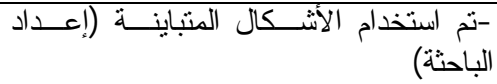 & & & \\
\hline $\begin{array}{c}-7-2-4 \\
1\end{array}$ & تر اكب عناصنر مستري & 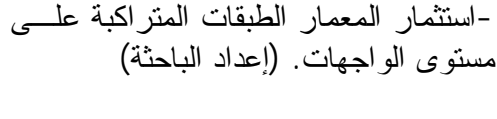 & 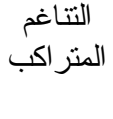 & & \\
\hline $\begin{array}{c}-8-2-4 \\
1\end{array}$ & عمودي & (إعداد الباحثة) (تذام هذا النمط بمستوى عمــودي. & 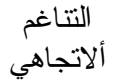 & & \\
\hline $\begin{array}{c}-8-2-4 \\
2\end{array}$ & أفقي & الباحثنة) توظيف التتاغم بمـستوى أفقــي(إعـــداد & & & \\
\hline
\end{tabular}

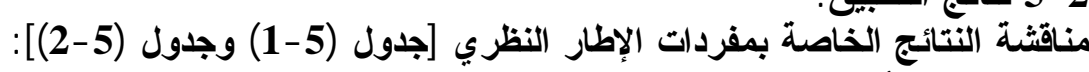
2 -5 -1تحليل أحادي لمفردات التناغم:

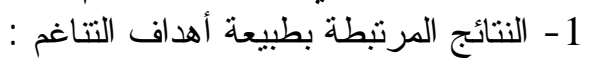

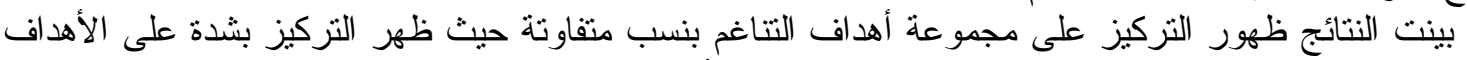

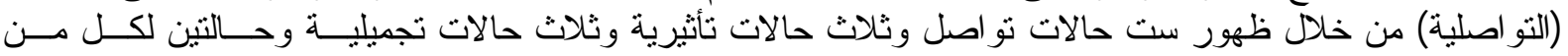

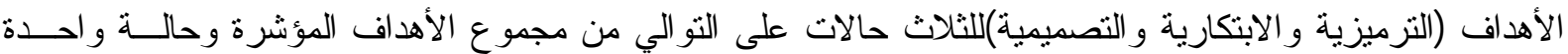

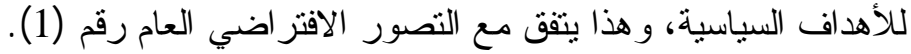

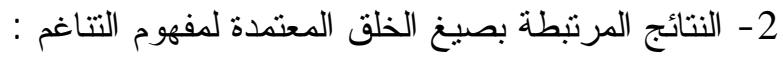

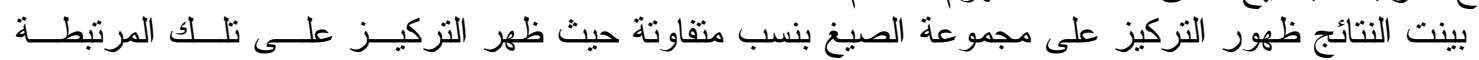

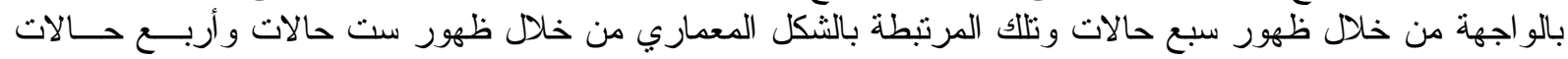

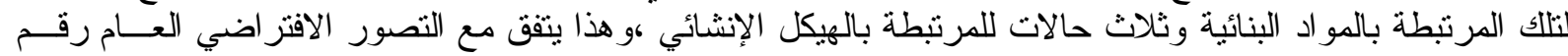

3 -النتائج المرتبطة بماهية مر اجع التتاغم:

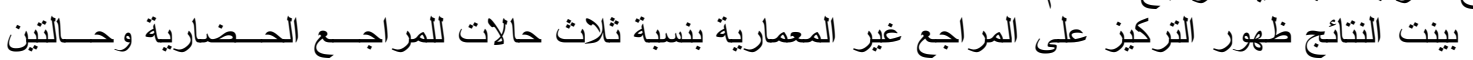

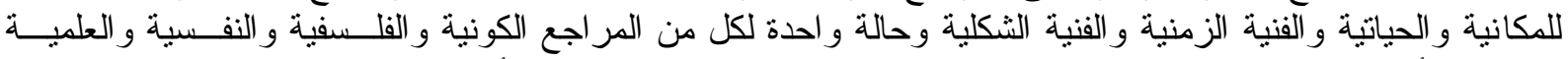

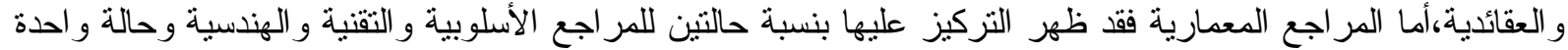

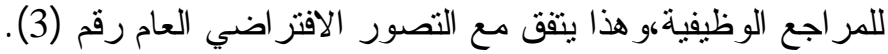

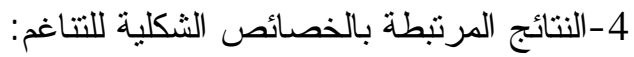

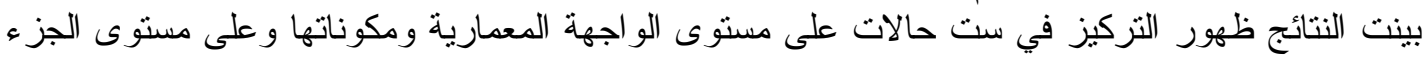

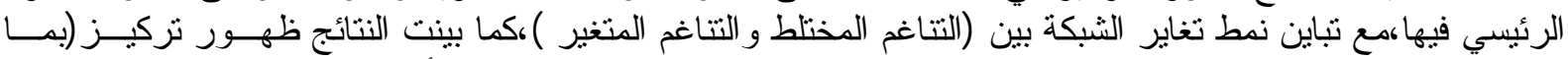

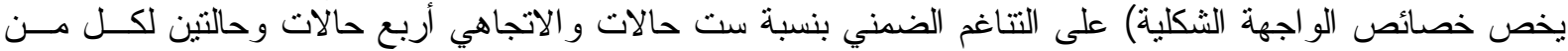

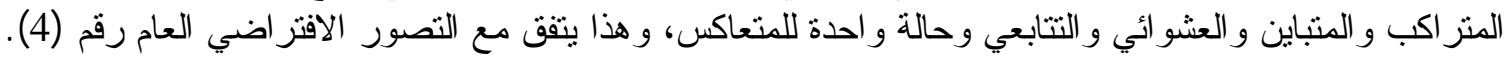
2 -5 - 2 - 2

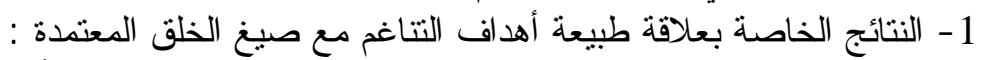

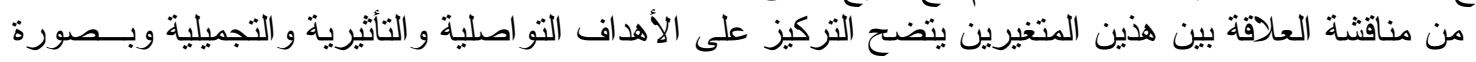

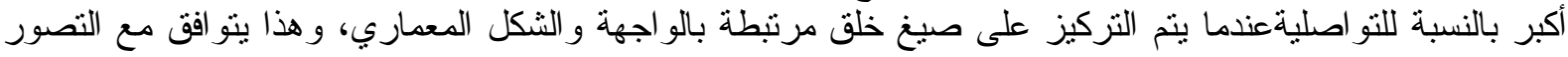

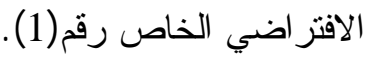

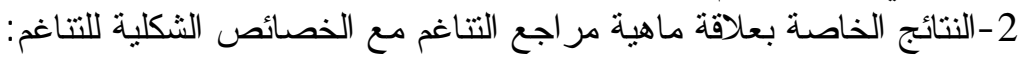

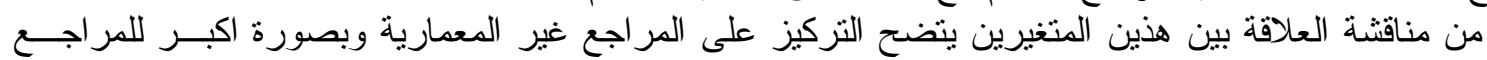

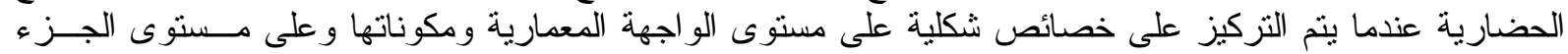

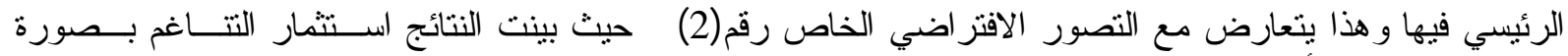

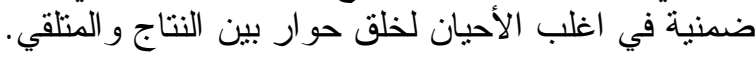

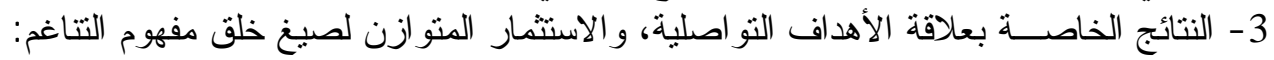




\section{Al-Rafidain Engineering $\quad$ Vol.17 $\quad$ No.5 $\quad$ October 2009}

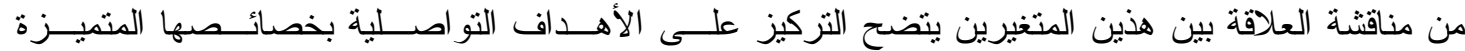

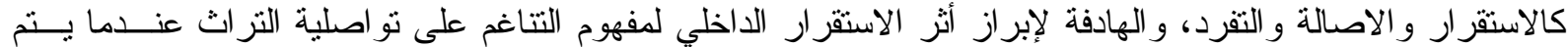

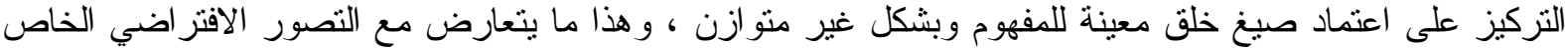

4 -النتائج الخاصة بطبيعة نوظيف التناغم في المشروعين: من مناقثة النتائج أنضح التباين بين المشروعين في طبيعة توظيف التتاغم ودرجة التركيز على قيم المفردات الرئيسية

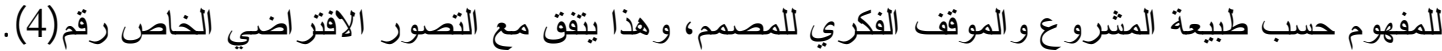

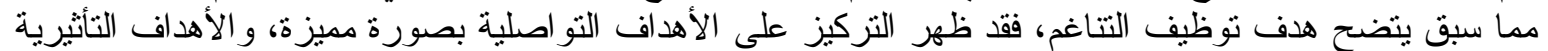

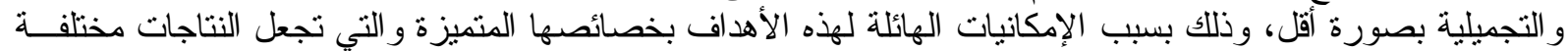

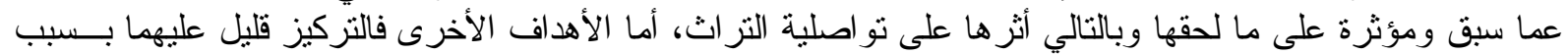

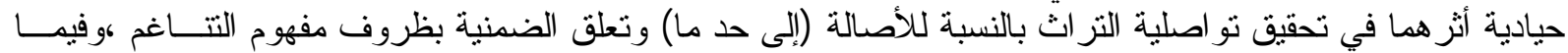

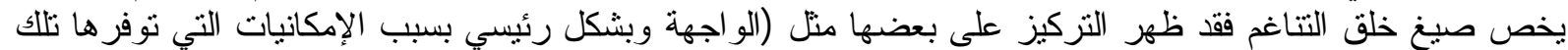

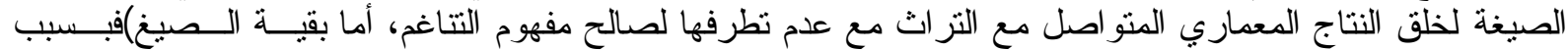

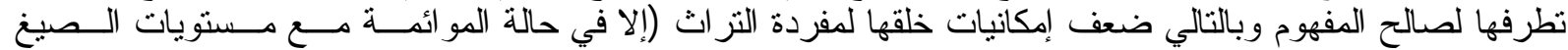

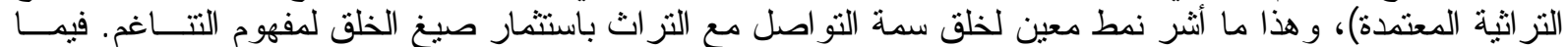

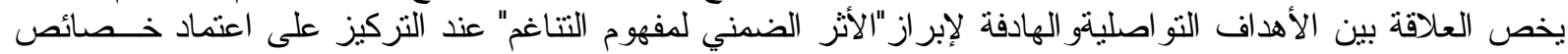

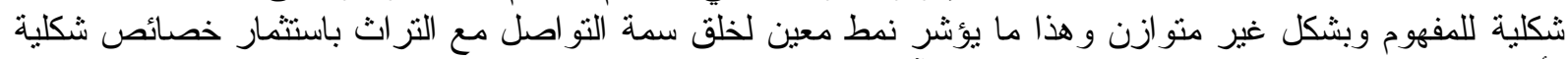

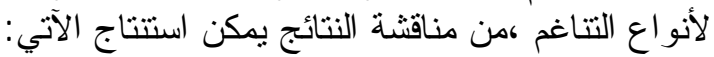

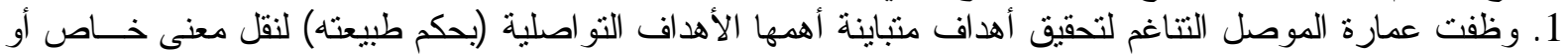

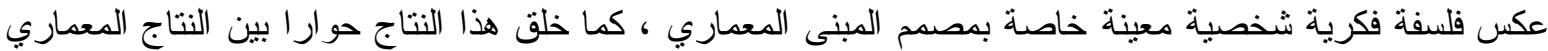

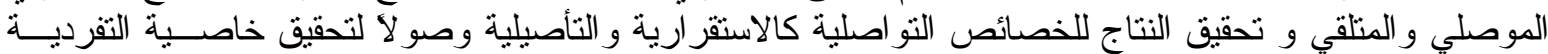

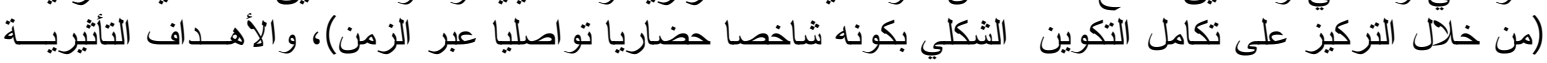

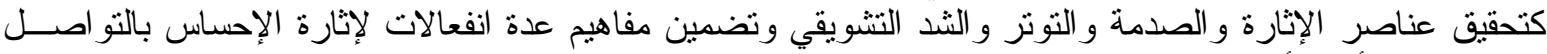

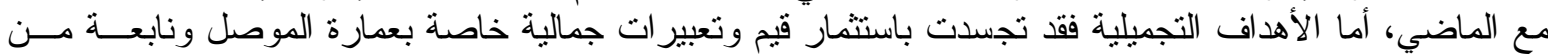

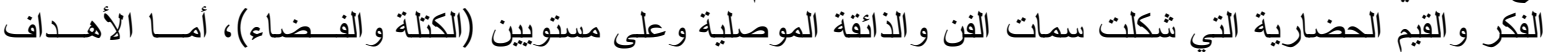

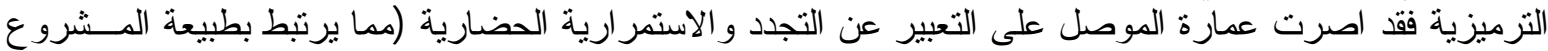

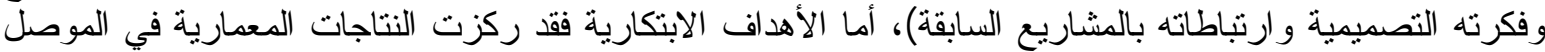

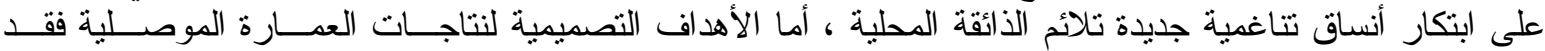

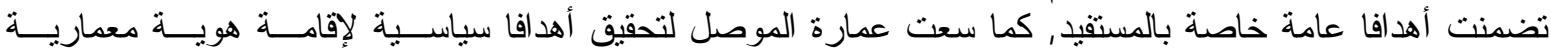

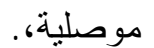

2. وظفت عمارة الموصل صيخ خلق عديدة مختلفة في طبيعتها لتحقيق التو اصلية للتراث من خلال استثمار التتاغم فـي

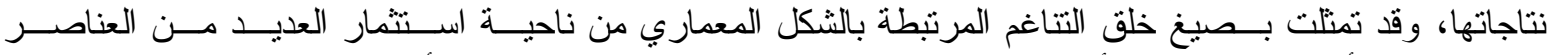

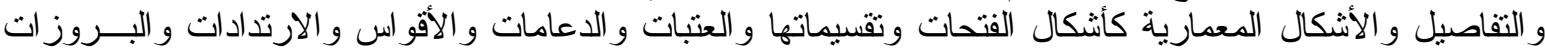

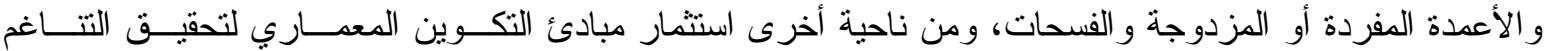

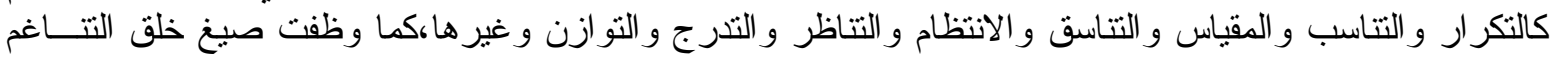

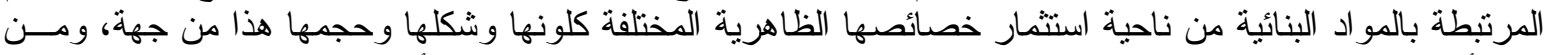

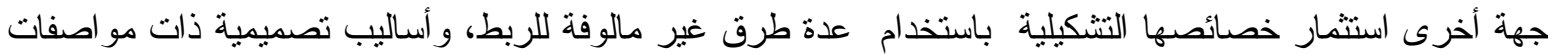

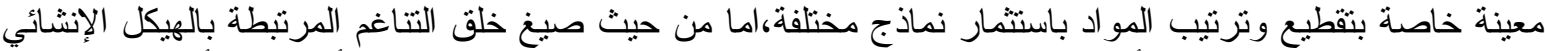

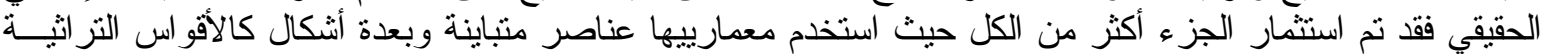

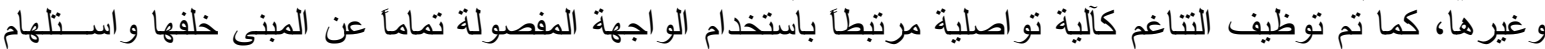

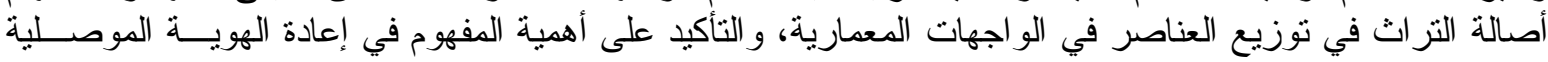

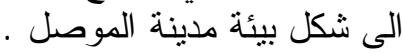

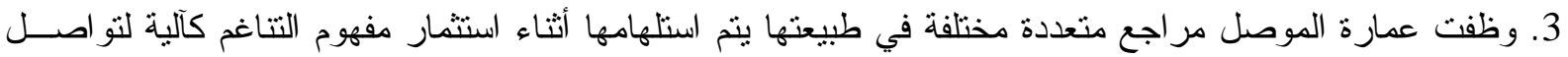

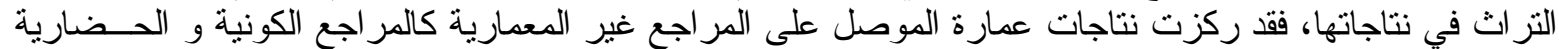

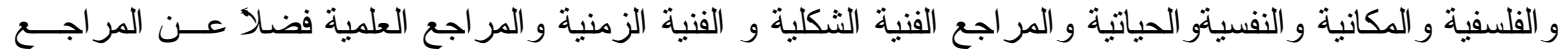

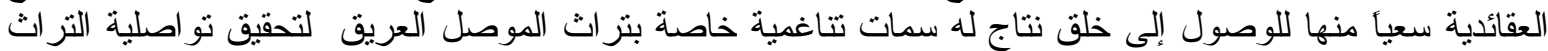

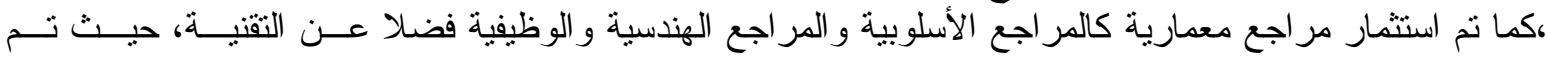




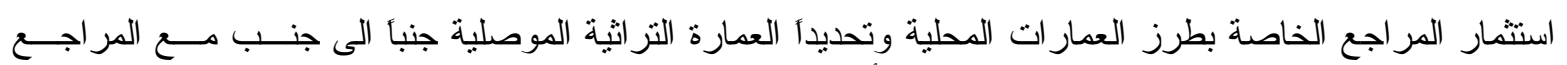

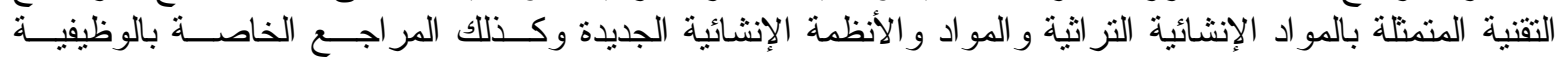
و المتعلقة بوظيفة المبنى المعماري فضلادلا عن المر اجع الهندسية التئية شملت الأشكال الهندسية (وتمنتلت بأثكال أساسية نقية كالمكعب و الاسطو انة و الكرة.... الخ) كارئة ،.

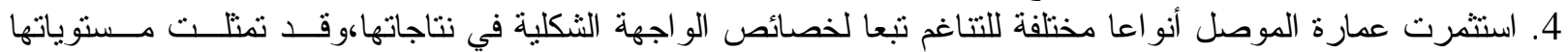

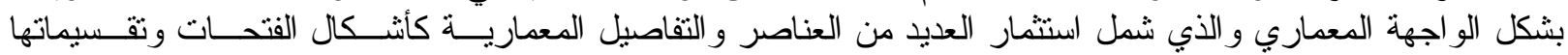

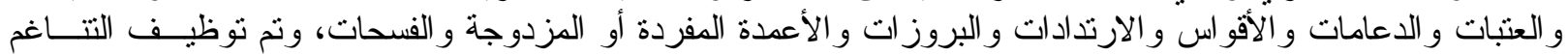

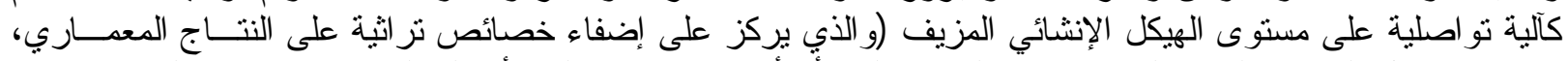

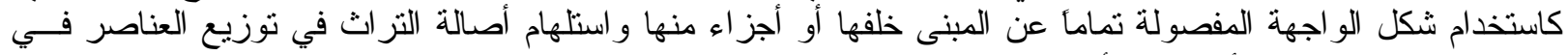

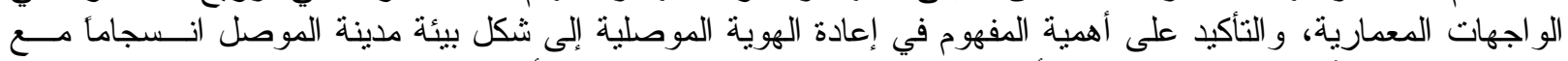

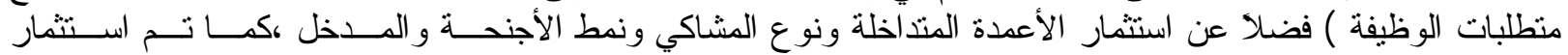

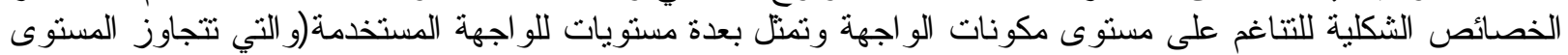

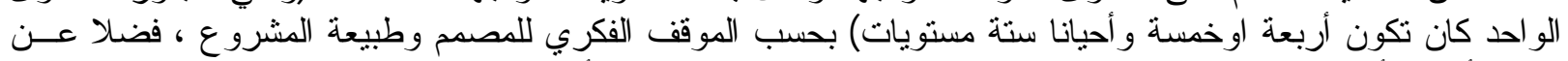

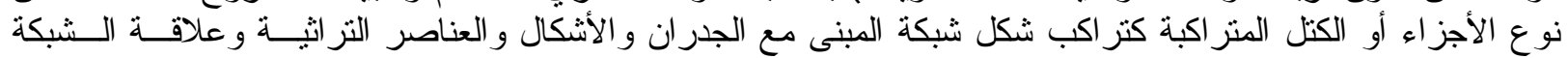

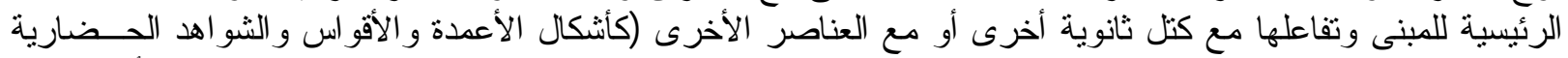

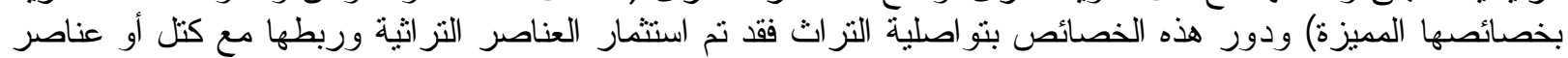

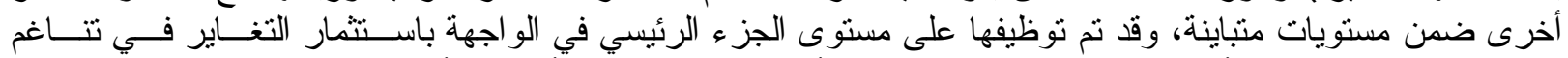

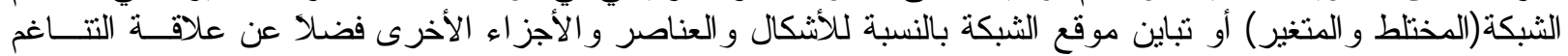

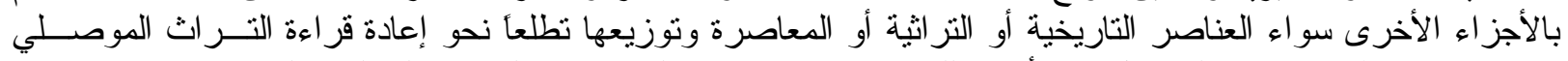

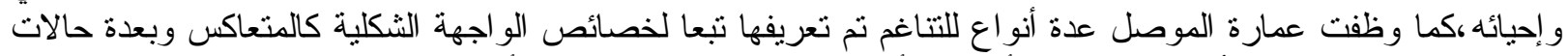

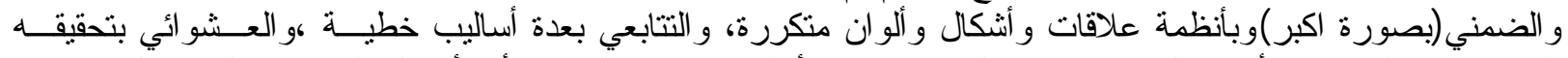

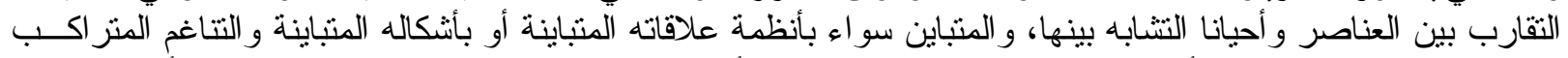

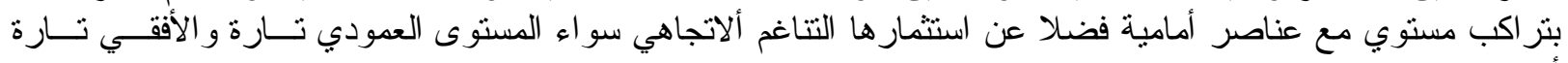

6- 2 - الاستنتاجات النهائية:

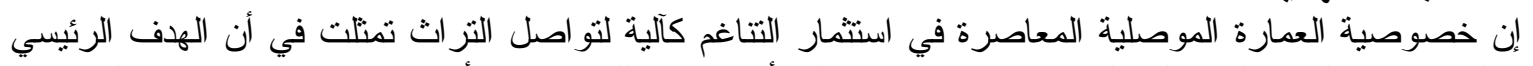

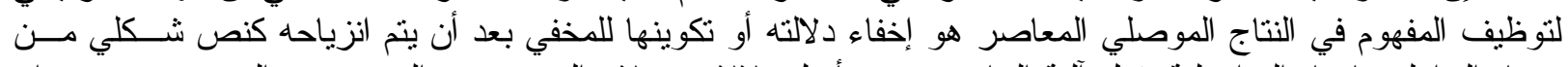

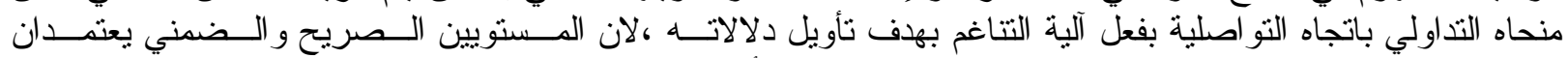

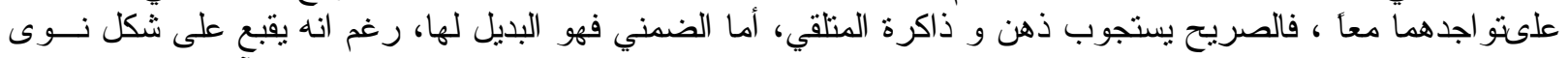

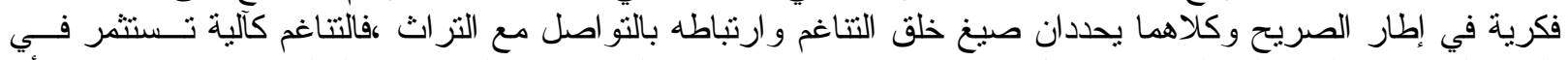

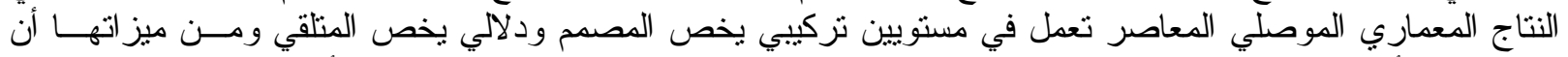

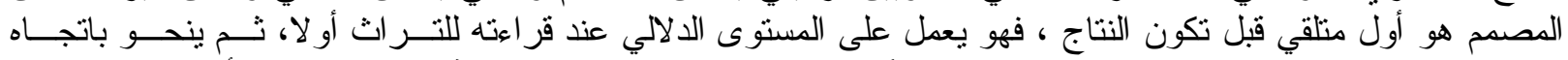

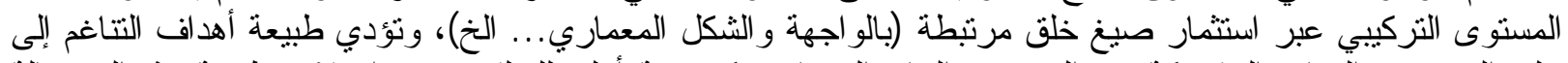

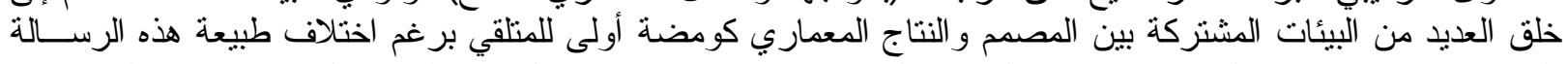

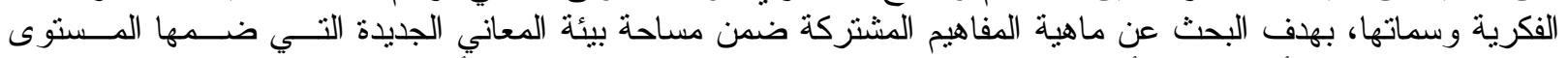

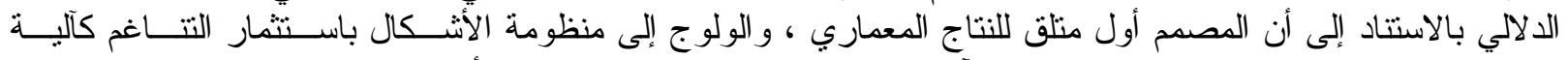

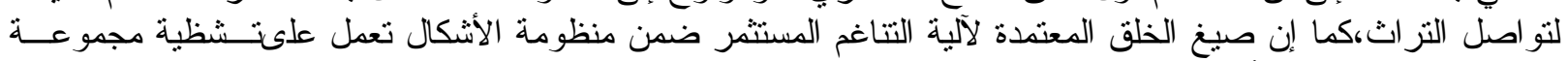

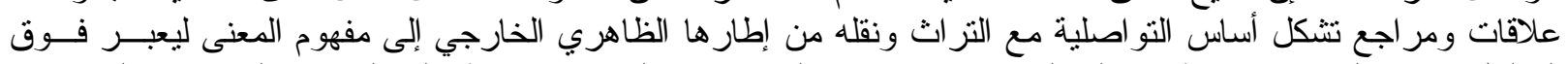

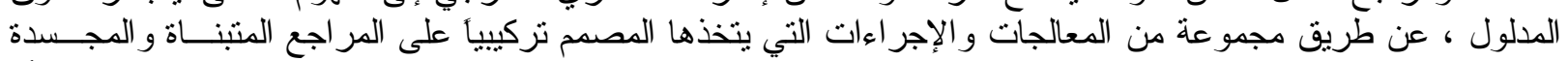

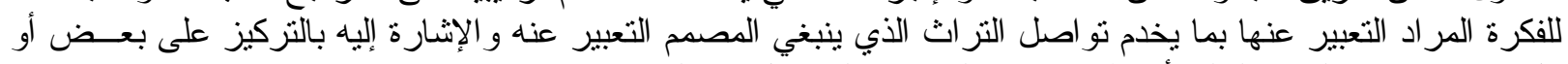

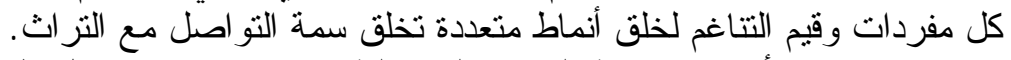

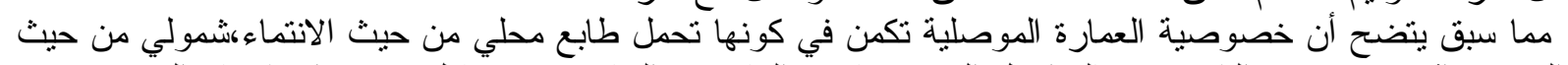

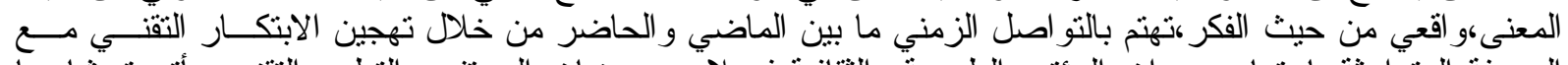

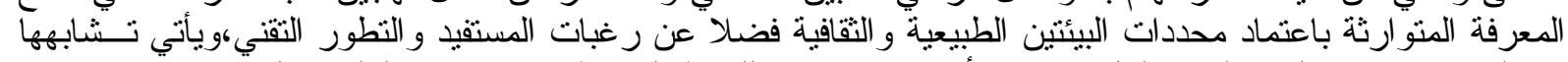

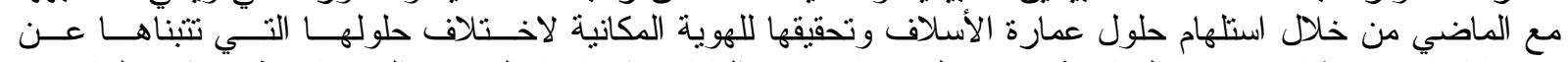

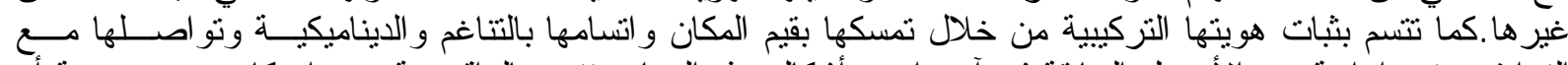

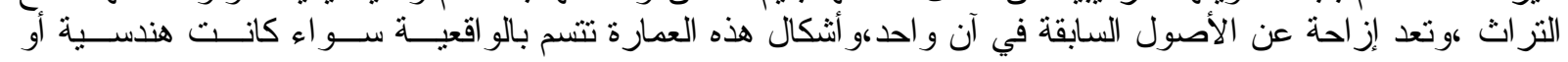




\section{Al-Rafidain Engineering $\quad$ Vol.17 $\quad$ No.5 $\quad$ October 2009}

عضوية مستجيبة لتعقيدات الأوضاع الإنسانية ذات (عدد متتوع من الإيقاعات و التتاغم الداخلي و الخارجي) ومحتو اهـا

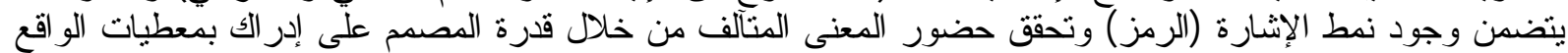

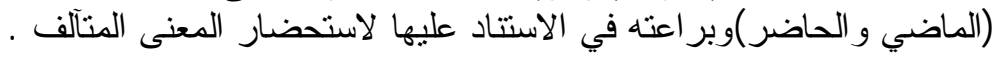

3. التوصيات :يمثل هذا البحث و احد من المجالات التي أخذت على عاتقها مهمة تأسيس قاعدة معلوماتية أولية لار اسات

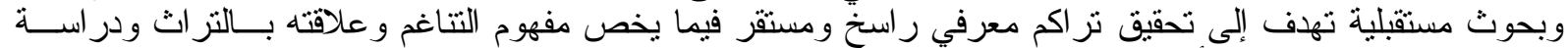

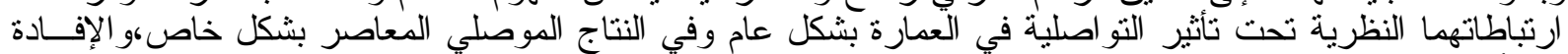

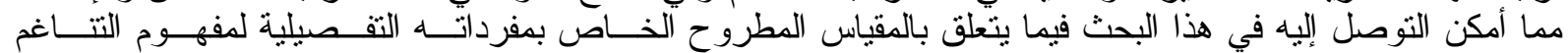

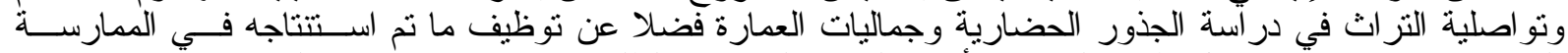

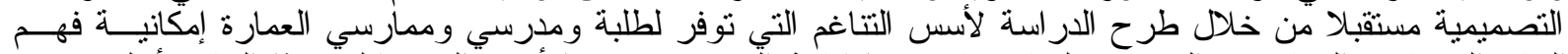

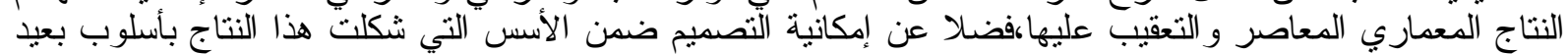

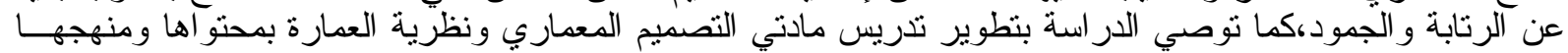

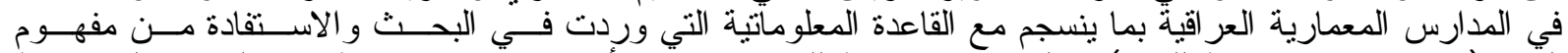

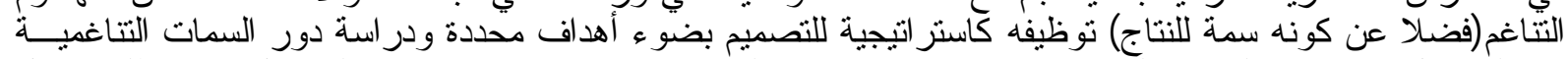

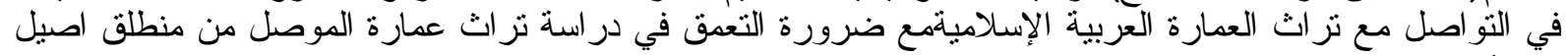

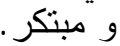

1. الجابري، محمد عابد" التز اث و الحداثة"، الطبعة الثانية، مركز در اسات الوحدة العربية، بيروت، 1999. 2.

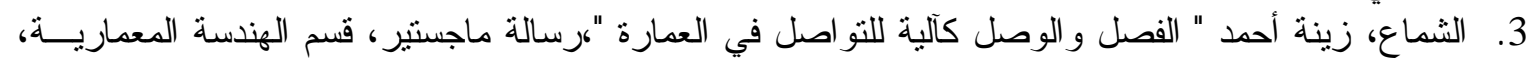
الجامعة التكنولوجية، بغداد،

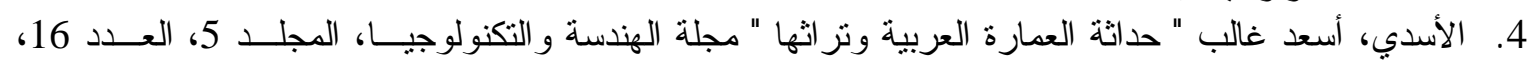

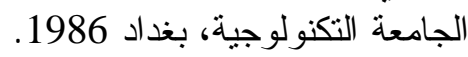

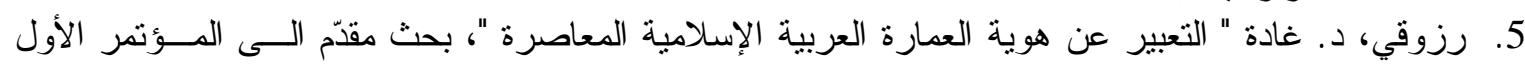

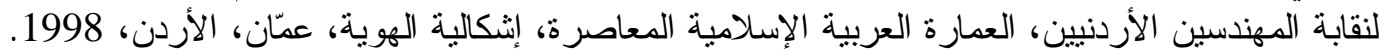

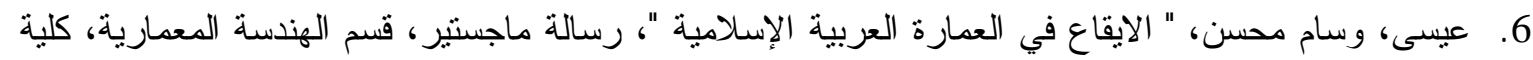

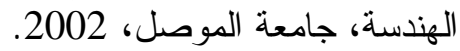
7. السلطاني،د. .خالد "الفنون تحتفي بذكرى ميلاده التسعين،محمد مكية،رائد المعمار العر اقي،مقالـــة فــي جريــدة

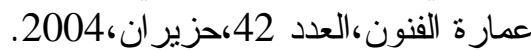
8. جليسك، جامز ، "الفوضى صناعة الفئ علم جديد"، عرض وتحليل : محمد عامر - عالم الفكر، المجلد العـشرون، العدد 1، الكويت، 1989.

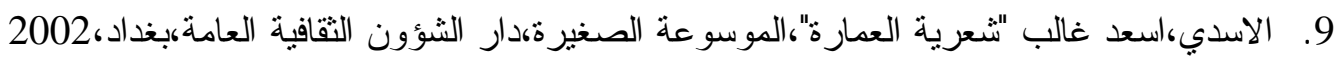

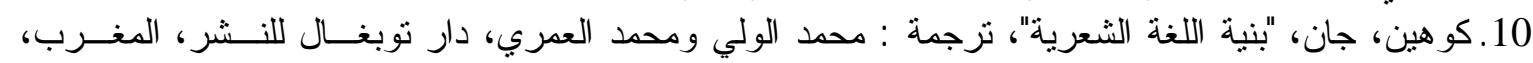
.1986 11. الفار ابي، أبي نصر محمد" الموسيقي الكبير "، تحقيق وشرح غطاس عبد الملك خثبة، دار الكاتـب العربـي

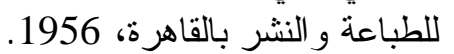

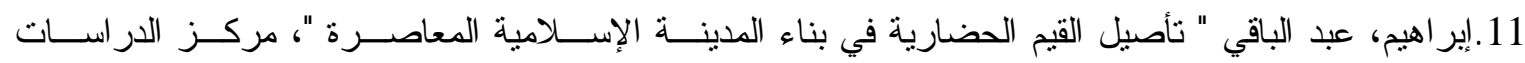
التخطيطية و المعمارية، 1982. 12. تنوني، د. رياض"الإحساس بالعمارة"، وز ارة التعليم العالي و البحث العلمي - الجامعــة التكنولوجيــة - قـسم

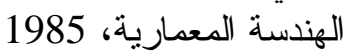

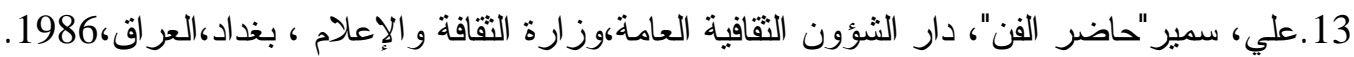

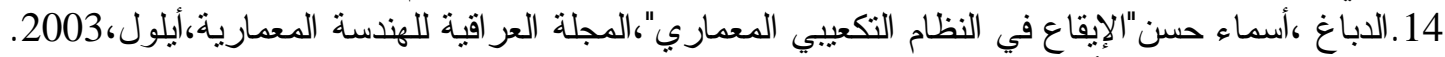

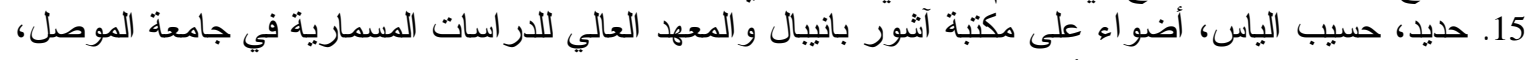

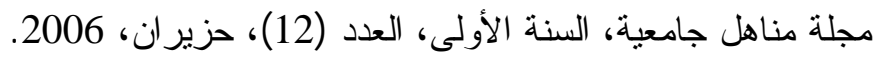

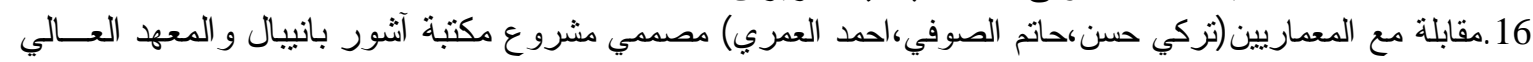

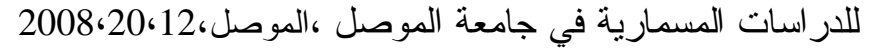




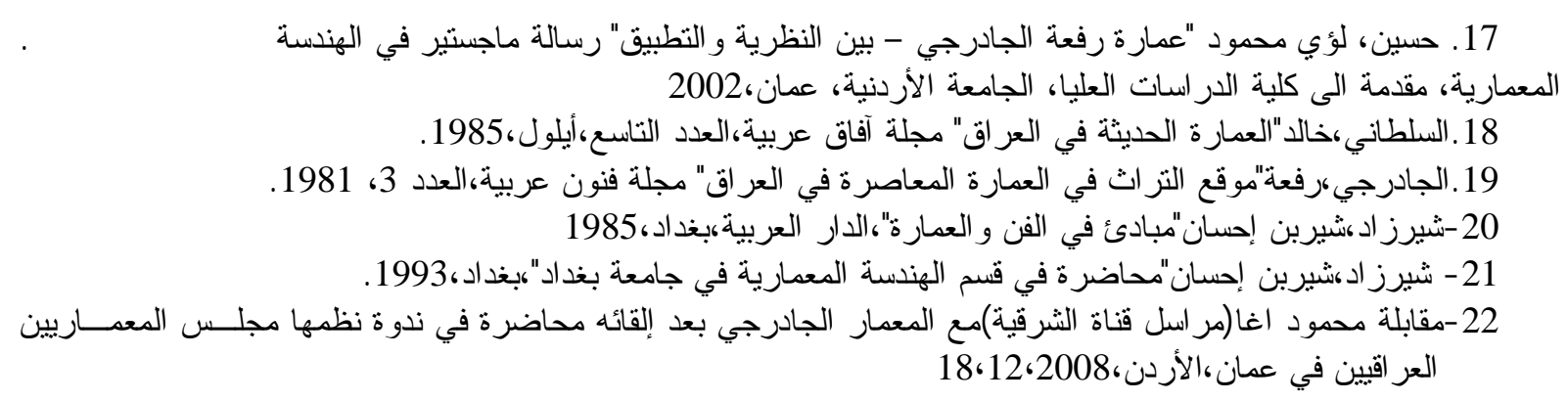

23.Nims, John Frederick: Western Wind, an introduction to poetry, Uni. Of Florida, Random Itouse, New York, 1978

24.Greene,Herb"Mind and image" Anessay on Art and Architecture ,Academy Edition ,London, 1980.

25. Mass Rasmuseen, Stern Eiler:" Experiencing Architecture", MIT Press, .U.S.A21.

26.Salingaros, Nicos,"A theory of Architecture", Thrmodynamics Analogy, Physics Essays, Vol 5,2006.

27.Scott, Robert G. " Design Fundamentals " McGraw-Hill Book Company, Inc. U.S.A.1951.

28.To Tonna" The Poetics of Arab-Islamic Architecture", 182-197, Department of Architecture and Urban Design, University of Malta, Nsida, Malta, Muqarnase, Volume 7, 1990.

29.Weinberg, Gerald "An Introduction to General System Thinking" New York, USA, 1975.

30.Abel Chris: Architecture and Identity, Architecture Press An imprint of Butler Worth, Hermann, London, 1996.

31.Ching, Francis D.K "Architecture Forms, Space \& Order" Van Nostrand Reinhold Company, Inc. New York, 1979.

32. Ching, Francis D.K "Interior Design Illustrated" Van Nostrand Reinhold Company, Inc. New York, 1987.

33.Jencks, Charles "Architecture Today" Academy Edition, London, 1988.

34.Jencks, Charles "The Architecture of Jumping Universe, AD Academy Edition, London, 1997.

35.Venturi, Robert "Igongraphy and Electronics upon A Generic Architecture", MIT Press, Cambridge, 1996.

36.Jencks, Charles "The Language of Post Modern Architecture", Academy Edition, London, 1991.

37.Jencks, Charles " The Architecture Signs", In: Sign Symbols, and Architecture", John Wiley \&Sons Ltd, 1980.

38.Graves, Maitlands: The Art of Color and Design, $2^{\text {nd }}$ edition, The Maple Press Company, York, PA. 1951. 

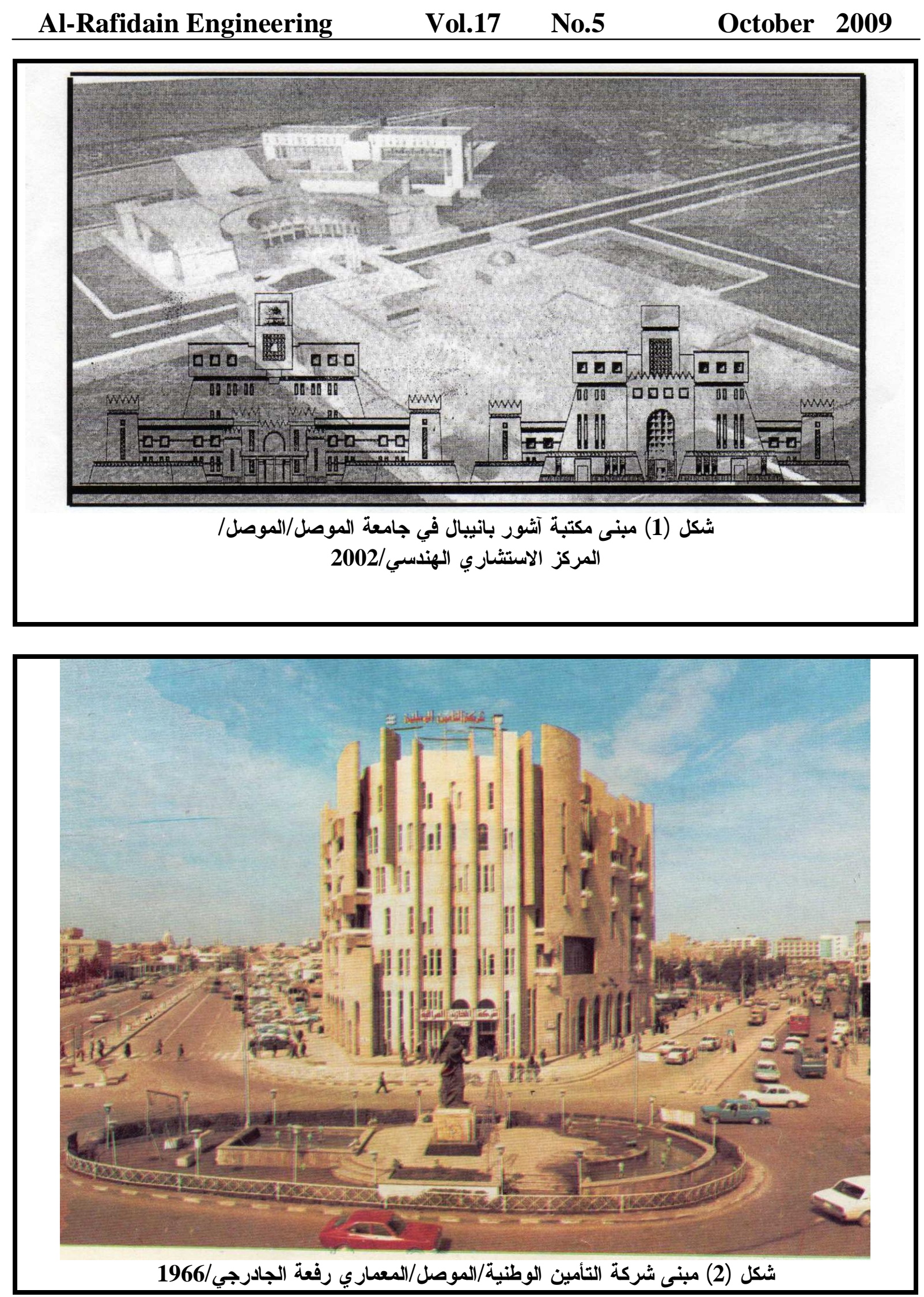

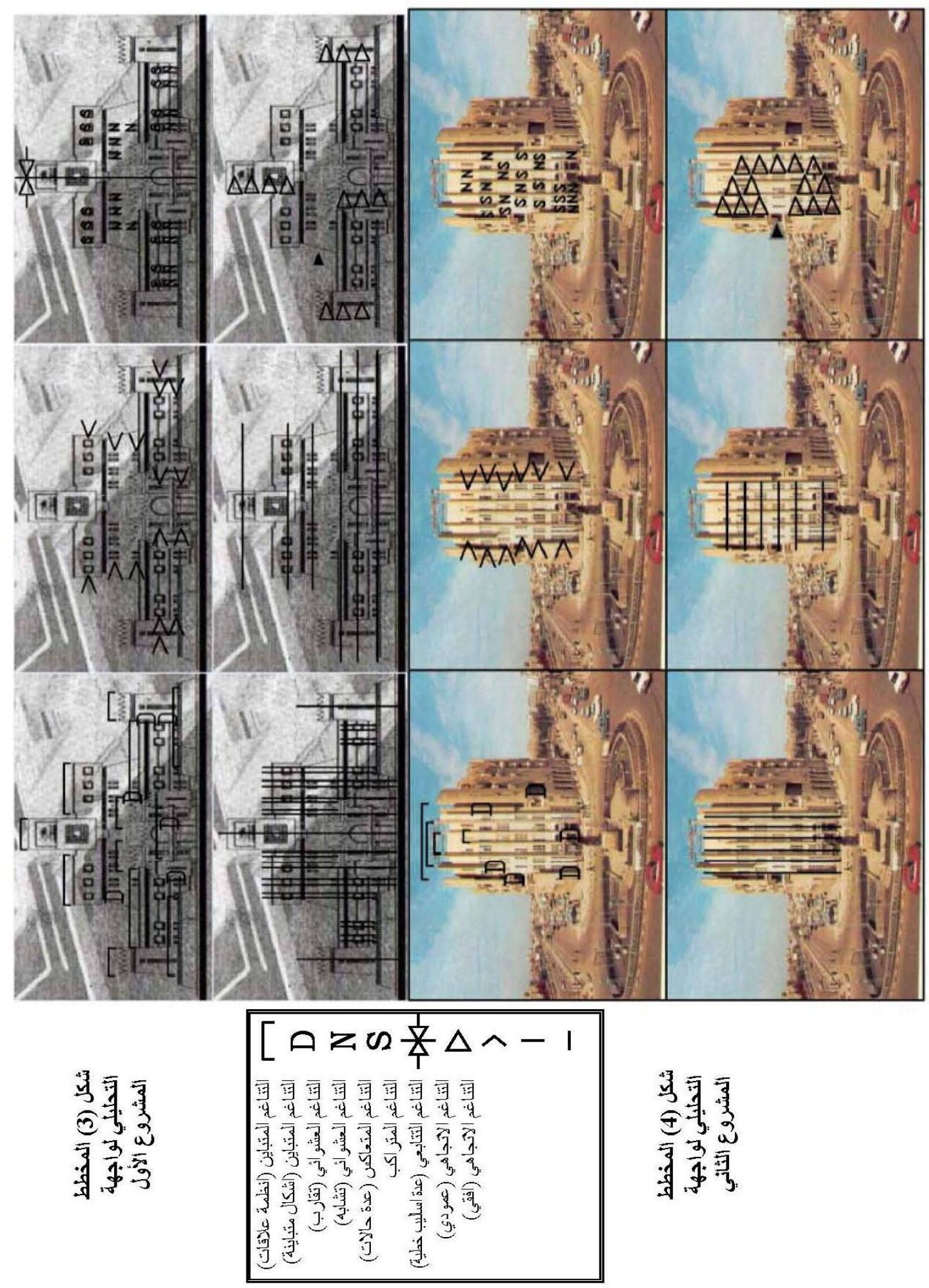

تم اجراء البحث في كلية الهنلسة - جامعة الموصل 